\title{
24. GEOCHEMISTRY AND ORIGIN OF EOCENE-OLIGOCENE METALLIFEROUS SEDIMENTS FROM THE CENTRAL EQUATORIAL PACIFIC: DEEP SEA DRILLING PROJECT SITES 573 AND $574^{1}$
}

\author{
Ian Jarvis. Department of Geology, City of London Polytechnic ${ }^{2}$
}

\begin{abstract}
Eocene-Oligocene metalliferous sediments and associated lithologies from the central equatorial Pacific are described in detail. Geochemical analyses of 54 sediment and 2 basalt samples are presented for 34 elements. Detailed stratigraphic and statistical analyses of these data, combined with mineralogic studies, indicate the presence of volcanic glass and seven main mineral phases: biogenic calcite and opal, Fe smectite, goethite, $\delta \mathrm{MnO}_{2}$, carbonate fluorapatite, and barite. Fe smectite formed by reactions between Fe oxyhydroxides and biogenic opal, causing the dissolution of calcite and the precipitation of barite. Diagenesis was oxic. Sediments have rare earth element distributions similar to those in seawater. The metal content of the sediments is related to competition between the supply rates of hydrothermal and biogenic particles, but has been enhanced by early diagenetic processes. Eocene-Oligocene metalliferous sediments compare closely to those currently being deposited in the Bauer Basin and on the flanks of the East Pacific Rise. There is, however, no evidence that they were deposited in close proximity to an active hydrothermal system.
\end{abstract}

\section{INTRODUCTION}

It has been known for some time that sediments near the East Pacific Rise are strongly enriched in Fe, Mn, and other transition metals relative to normal pelagic sediments (Murray and Renard, 1891; Revelle, 1944; Boström and Peterson, 1966; Boström et al., 1969; Bender et al., 1971). It is generally accepted that the metals were leached from the basaltic crust by seawater hydrothermal systems (Corliss, 1971; Bonatti et al., 1972; Dymond et al., 1973; Piper, 1973; Bonnatti, 1975; Dymond and Veeh, 1975; Cronan, 1980; Dymond, 1981; Thompson, 1983), which subsequently deposited them as authigenic precipitates on the seafloor. Studies of the mineralogy, geochemistry, and origin of metalliferous sediments in the central Pacific (Fig. 1) have concentrated on the recent sediments of the East Pacific Rise (Sayles and Bischoff, 1973; Heath and Dymond, 1977, 1981; Lyle, 1981; Marchig and Gundlach, 1982; Marchig et al., 1982), the Bauer Deep (Sayles et al., 1975; Dymond and Veeh, 1975; Heath and Dymond, 1977; Dymond, 1981; McMurtry et al., 1981; Lyle, 1981; Field et al., 1981), and the Galapagos Hydrothermal Mounds Field (Corliss et al., 1978; Hekinian et al., 1978; Edmond, Measures, McDuff, et al., 1979; Edmond, Measures, Mangum, et al., 1979; Williams et al., 1979; Varnavas and Cronan, 1981; Honnorez et al., 1981; Honnorez, Von Herzen, et al., 1983; Barrett and Friedrichsen, 1982; Moorby, 1983). Relatively few data are available on the ancient analogs of these deposits that have been cored by DSDP to the west of the East Pacific Rise.

Eocene-Oligocene metalliferous sediments occur in the central Pacific (Fig. 1) in the base of the sediment col-

\footnotetext{
${ }^{1}$ Mayer, L., Theyer, F., et al., Init. Repts. DSDP, 85: Washington (U.S. Govt. Printing Office).

2 Present address: Department of Geology, Kingston Polytechnic, Penrhyn Road, Kingston-upon-Thames, Surrey KT1 2EE, United Kingdom.
}

umn at DSDP Sites 74 and 75 (Tracey et al., 1971; von der Borch et al., 1971), Sites 77 and 78 (Hays et al., 1972), and Sites 159, 160, and 162 (van Andel, Heath, et al., 1973; Cronan, 1973). Miocene metalliferous sediments occur in the base of the sediment column at Site 81 (Hays et al., 1972) and in the upper part of the sediment column at Sites 74 (von der Borch et al., 1971) and 159 (Cronan, 1973). No study of these deposits has been published since the work of Cronan (1973, 1976; Cronan and Garrett, 1973), although Leinen (1981) described similar material from the northeast Pacific. Comparable Eocene-Oligocene sediments were collected on DSDP Leg 85 at Sites 573 and 574, and a stratigraphic succession including 54 sediment and 2 basalt samples was collected from these two localities for geochemical analysis. In this chapter, I describe the geochemistry of these samples, discuss the partitioning of elements between different mineral phases in the sediment, and examine the constraints these data place on the origin of the ferromanganese component.

\section{MINERALOGY}

Pelagic sediments in the eastern equatorial Pacific are composed dominantly of calcium carbonate (low-Mg calcite), biogenic opal, and clay minerals. Common accessory phases include quartz, feldspar, barite, apatite (fish debris), zeolites (phillipsite and clinoptilolite), and volcanic glass. Metalliferous sediments contain these components admixed with varying proportions of ferromanganese minerals. The ferromanganese phase was initially regarded as being X-ray amorphous (Boström and Peterson, 1966, 1970; von der Borch and Rex, 1970; von der Borch et al., 1971; Bender et al., 1971), but the application of ultraslow scan X-ray diffraction (XRD) and other techniques has shown that a number of discrete mineral phases can be recognized (Dasch et al., 1971; Dymond et al., 1973; Sayles and Bischoff, 1973; Sayles et al., 1975; Heath and Dymond, 1977; Dymond and Ek- 


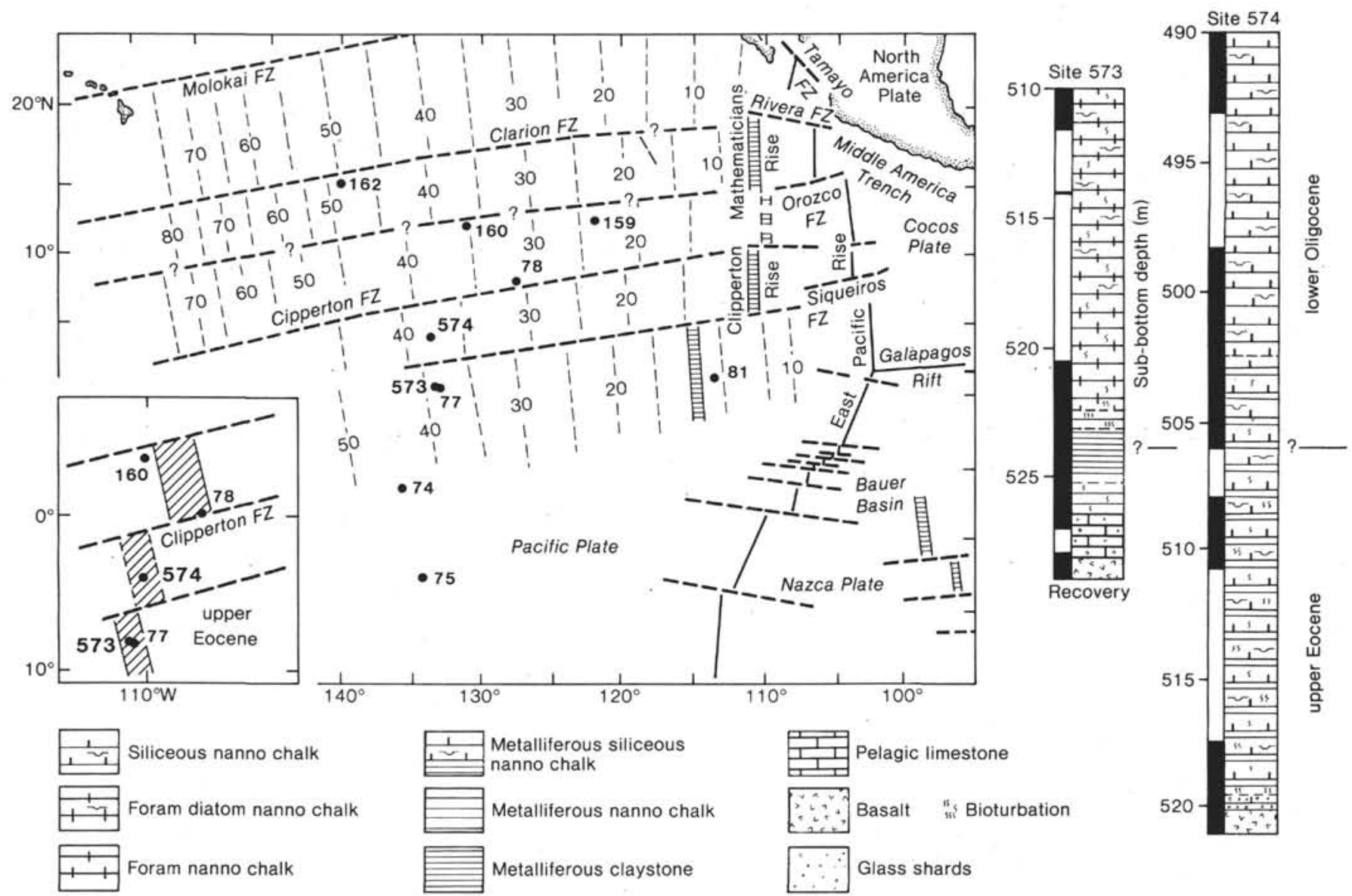

Figure 1. Location and stratigraphy of metalliferous sediments from DSDP Sites 573 and 574 . The base map is a tectonic and basement isochron chart of the central equatorial Pacific (after van Andel et al., 1975). Bold numbers and dots indicate DSDP drilling sites where metalliferous sediments have been recovered. Solid line represents the ridge crest; broad striped zone is extinct ridge crest; heavy dashed lines are fracture zones (FZ). Light dashed lines with numbers 10 to 80 are basement isochrons, expressed in millions of years. Inset shows a reconstruction of the late Eocene ridge crest and the location of drilling sites based on the back-track model of van Andel et al. (1975). Stratigraphic columns are shown to the right; dark stripes indicate recovered intervals; light stripes indicate no recovery.

lund, 1978). A brown Fe smectite (generally identified as Fe montmorillonite) is an important, and commonly dominant, component in many deposits. Nontronite (a yellow-green, aluminum-poor Fe smectite) is the major iron-bearing phase in the Galapagos Hydrothermal Mounds Field (Honnorez et al., 1981; Honnorez, Von Herzen et al., 1983), and authigenic Fe montmorillonite is an important constituent in recent pelagic clays throughout the eastern and central Pacific (Aoki et al., 1974; Hein et al., 1979). Other minerals identified in metalliferous sediments include goethite (the dominant phase in some basal deposits), psilomelane, $\delta \mathrm{MnO}_{2}$, birnessite, and todorokite. The wide range of manganese mineralogy reflects the inclusion of manganese micronodules and crusts in many deposits.

Preliminary mineralogic analysis of Leg 85 samples indicates the occurrence of varying proportions of calcite, poorly crystallized Fe smectite and goethite, $\delta \mathrm{MnO}_{2}$, carbonate-fluorapatite, barite, quartz, and plagioclase feldspar.

\section{MATERIAL}

Eocene-Oligocene metalliferous sediments vary from pale-brown, metalliferous nannofossil chalks (composed of variable amounts of radiolarians, diatoms, and foraminifers) that are tens of meters thick and contain only a small percentage of $\mathrm{Fe}_{2} \mathrm{O}_{3}$, to dark-brown, metalliferous claystones only a few meters thick with greater than 30 wt. $\% \mathrm{Fe}_{2} \mathrm{O}_{3}$. These metalliferous sediments either immediately overlie basalt or are separated from igneous rocks by a decimeter-thick bed of strongly indurated pelagic limestone containing abundant volcanic debris. The deposits have either sharp or transitional bottoms and tops and are commonly bioturbated. At Sites 74 and 75 decimeter thick metalliferous units are interbedded with pelagic oozes and have sharp but burrowed contacts; elsewhere (e.g., Sites 573 and 574) only a single metalliferous unit is present.

The holes cored continuously to basement on Leg 85 (at Sites 573 and 574) contained metalliferous sediments at the base of the sediment column. In both cases the deposits span the Eocene/Oligocene boundary (Barron et al., this volume), although the exact position of the boundary (Fig. 1) is difficult to determine because of the absence of microfossils (Site 573) or because of disparity in its position when defined using different fossil groups (Site 574). Hole 573B contains $4 \mathrm{~m}$ of metalliferous claystone and chalk overlying $1.4 \mathrm{~m}$ of strongly in- 
durated, upper Eocene pelagic limestone and basalt (Fig. 1). Hole $574 \mathrm{C}$ contains $7.5 \mathrm{~m}$ of metalliferous chalks resting on basalt (Fig. 1). The top of the metalliferous unit at Site 573 displays numerous burrows (Planolites, Chondrites, and Zoophycos) filled with lighter colored sediment. The metalliferous chalks at Site 574 are burrow mottled throughout. The metalliferous component consists predominantly of dark brown, clay-sized grains and silt-sized aggregates mixed in varying proportions with biogenic debris. Scattered 0.5 to $3 \mathrm{~mm}$ glass shards and small $0.5 \mathrm{~mm}$ ferromanganese micronodules occur at both sites and are most abundant toward the base of the sections.

\section{METHODS}

Samples were taken on board the Glomar Challenger at approximately $20 \mathrm{~cm}$ intervals through the recovered interval of metalliferous sediment. In addition, representative material was selected from the pelagic sediments above and below the metalliferous units and from the underlying basalt. Disturbed sections and sediment near the core liners were avoided to minimize possible contamination.

Samples were dried at $60^{\circ} \mathrm{C}$ for $24 \mathrm{hr}$., and crushed in an agate mortar and pestle. Powders were desalinated by stirring in $500 \mathrm{ml}$ of warm deionized water for $2 \mathrm{hr}$. followed by filtration and rinsing with fresh deionized water. Samples were redried and crushed prior to storage in glass vials.

The mineralogy of selected samples was determined by X-ray diffraction (XRD) at the Institute of Oceanographic Sciences (Wormley, Surrey, U.K.). Powders were reground in a tungsten-carbide tema to minimize grain-size variations between samples and then mounted in random-aggregate cavity mounts. Analyses were performed using $\mathrm{Cu}$ $\mathrm{K} \alpha$ radiation at $40 \mathrm{kV} / 20 \mathrm{~mA}$ and a Philips PW 1050 goniometer with AMR monochromator. Scan speeds of $0.25^{\circ} 2 \theta / \mathrm{min}$ were used throughout.

Geochemical analyses were performed on 54 sediment and 2 basalt samples. Three separate solution methods were applied to $0.5 \mathrm{~g}$ subsamples of the processed powders: (1) Fusion with lithium-metaborate in carbon crucibles and digestion of the hot fusion beads in $0.5 \mathrm{~N}$ $\mathrm{HNO}_{3}$; (2) Open digestion in PTFE beakers using $\mathrm{HClO}_{4}$ and $\mathrm{HF}$ followed by $\mathrm{HClO}_{4}$ and $\mathrm{H}_{3} \mathrm{BO}_{3}$ acids; final solutions were made up in 1 $N \mathrm{HCl}$; and (3) Partial digestion for $30 \mathrm{~min}$. in warm $1 \mathrm{~N} \mathrm{HCl}$; solutions were filtered immediately and made up to volume with additional $1 \mathrm{~N} \mathrm{HCl}$.

Fusion solutions were analyzed simultaneously for $\mathrm{Si}, \mathrm{Fe}, \mathrm{Mn}$, and Ca using a Philips PV8210 Inductively Coupled Plasma (ICP) Spectrometer at the Department of Geology, King's College, London. The open and partial digestions were analyzed simultaneously by ICP for $\mathrm{Al}, \mathrm{Fe}, \mathrm{Mg}, \mathrm{Mn}, \mathrm{Ca}, \mathrm{Na}, \mathrm{K}, \mathrm{P}, \mathrm{Ba}, \mathrm{Cr}, \mathrm{Co}, \mathrm{Cu}, \mathrm{Li}, \mathrm{Ni}, \mathrm{Sc}, \mathrm{Ti}, \mathrm{V}$, and $\mathrm{Zn}$. The $\mathrm{HCl}$-soluble solutions were additionally analyzed for $\mathrm{B}$. Values of $\mathrm{K}$ were checked by atomic absorption (AA) spectrometry. The rare earth elements (REE) and $\mathrm{Y}$ were extracted from solutions prepared by a separate $\mathrm{HF}-\mathrm{HClO}_{4}$ open digestion and using a cation separation procedure modified from Walsh et al. (1981). La, Ce, Pr, Nd, $\mathrm{Sm}, \mathrm{Eu}, \mathrm{Gd}, \mathrm{Dy}, \mathrm{Ho}, \mathrm{Er}, \mathrm{Yb}, \mathrm{Lu}$, and $\mathrm{Y}$ were determined simultaneously by ICP. Calibration curves were constructed using artificial composite standards (made from BDH and Eldrich standard solutions for atomic absorption and from Specpure chemicals) and were calculated to match closely the range of values expected for each element in the unknowns. Careful matching of matrices was essential to minimize interference effects. Raw intensity data were processed on a Digital PDP 11-34 computer, utilizing a program developed by the author, which incorporates drift and blank corrections. The REE data were additionally corrected for interelement interferences by $\mathrm{Ba}, \mathrm{Ca}, \mathrm{Sr}, \mathrm{Ti}$, and $\mathrm{Zr}$ to compensate for the small proportion of these elements that remained after the cation exchange procedure was completed.

Analytical precision as determined by replicate analyses is better than $\pm 5 \%$ for most elements and better than $\pm 3 \%$ for all of the REE present in amounts $>0.2 \mathrm{ppm}$. Elements with poorer precisions are B, $\mathrm{Ba}, \mathrm{Ni}( \pm 10 \%)$, and $\mathrm{Cr}( \pm 20 \%)$. Detection limits are below $5 \mathrm{ppm}$ for all trace elements. Detection limits for the REE are below chon- dritic levels. By reference to international standards, absolute accuracy is judged to be within the limits indicated by the precision.

$\mathrm{Fe}, \mathrm{Mn}$, and $\mathrm{Ca}$ values obtained from the fusion and open-digestion solutions were averaged prior to further data reduction. The REE and $\mathrm{Y}$ were not determined on the $\mathrm{HCl}$-soluble portions, and levels of $\mathrm{Cr}$ were generally below detection limits in these solutions. Finally, $\mathrm{HCl}$-soluble values were compared with their corresponding wholesediment values to determine whether any elements had been extracted completely by the differential leaching. It was concluded that $\mathrm{Ca}, \mathrm{P}$, and $\mathrm{Sr}$ (plus Ba at Site 574) values were indistinguishable (within the limits of the precision) between the two data sets, and values were averaged for each sample. Analytical results are presented in Appendixes A to $\mathrm{D}$.

The metalliferous sediments generally contain little $\mathrm{Ca}$, but the transitional sediments above and below them are characterized by highly variable $\mathrm{Ca}$ contents (e.g., Site 573, 3.04-54.70\% $\mathrm{CaO}$; Appendix A). Comparisons between the carbonate content and the percentage $\mathrm{Ca}$ in pelagic sediments from the eastern Pacific (Sayles et al., 1975; Dymond et al., 1976) have shown that $<2 \% \mathrm{CaO}$ occurs in the noncarbonate fraction. Pelagic clays generally contain $<1 \% \mathrm{CaO}$ (Turekian and Wedepohl, 1961; Chester, 1965; Dymond and Eklund, 1978; Barrett et al., 1983). Other elements (with the notable exception of Sr) vary inversely with the amount of $\mathrm{Ca}$, indicating that although calcium carbonate has a major effect on the bulk composition of the sediments, it does not control the distribution of minor and trace elements. Compositional variations in the noncarbonate fraction are best assessed, therefore, if the data are recalculated on a carbonate-free basis (CFB). It is simplest to assume that all $\mathrm{Ca}$ occurs as $\mathrm{CaCO}_{3}$ since the small percentage of $\mathrm{Ca}$ that does occur in other minerals (zeolites, feldspar, apatite, and clay minerals) should have no significant effect on the recalculated data. Where the carbonate content is high, however, small errors in Ca determinations produce large variations in the CFB values of other elements (Boström et al., 1976; Dymond et al., 1976). Calcium values reported here (Appendix A) were determined from three separate dissolutions of each sample; nevertheless, possible inaccuracies must be considered when interpreting CFB data.

\section{RESULTS}

The sampling scheme was devised to allow a stratigraphic assessment of interelement variation and was used in conjunction with the application of statistical techniques. Statistical techniques have proven to be a valuable tool in assessing interelement correlations and in determining the partitioning of elements between different mineral phases (Cronan, 1969b, 1972, 1976; Sayles et al., 1975; Marchig and Gundlach, 1982), but both methods are necessary to delimit possible postdepositional mobilization of elements in the sediment (e.g., Heath and Dymond, 1981). Consequently, stratigraphic analysis of geochemical data at Sites 573 and 574 has been combined in this study with an assessment of interelement variations.

\section{Site 573}

Sediments analyzed at Site 573 vary from white foraminifer diatom nannofossil chalk and pelagic limestone to dark brown metalliferous claystone (Figs. 1 and 2). The geochemical variation reflects this wide range in lithology.

\section{Major Elements}

Major element data (Fig. 2 and Appendix A) indicate a number of independent trends. $\mathrm{Fe}, \mathrm{Mn}$, and $\mathrm{P}$ have similar distributions, forming broad symmetric peaks that reach maxima in the middle of the metalliferous claystone ( $\sim 524 \mathrm{~m}$ sub-bottom depth) and gradually drop 


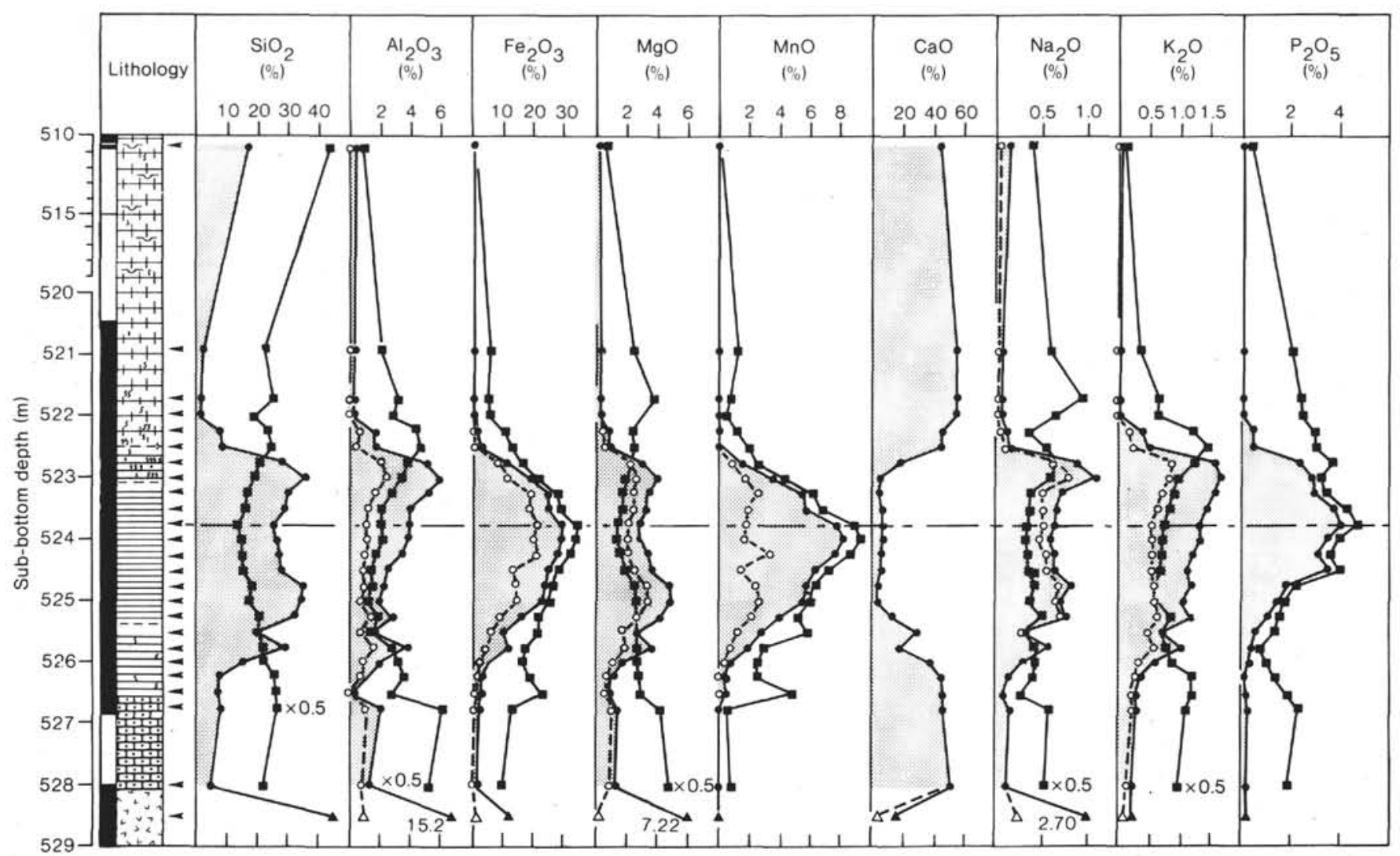

Figure 2. Stratigraphic variation of major elements in metalliferous sediments and associated lithologies at Site 573. For key to lithostratigraphic symbols see Figure 1. Stippled areas and black dots indicate bulk compositions; circles are $\mathrm{HCl}$-soluble values. Squares are bulk compositions recalculated on a CFB; they represent the composition of the noncarbonate fraction. Scale factors (e.g., $\times 0.5)$ relate to CFB data; filled triangles indicate the bulk composition of the tholeitic basalt and open triangles the $\mathrm{HCl}$-soluble values for the basalts.

off to low concentrations at the base and top of the unit. Their distribution is reflected in the darker color of the sediment. $\mathrm{Si}, \mathrm{Al}, \mathrm{Mg}, \mathrm{Na}$, and $\mathrm{K}$ also show large increases within the metalliferous unit but display approximately bimodal distributions that peak at the top and toward the base of the unit. $\mathrm{Ca}$ has a distribution that is the inverse of the Si group of elements. These major groupings may be loosely ascribed to ferromanganese, aluminosilicate, and carbonate phases in the sediment. The relative amplitude of the two peaks displayed by the aluminosilicate group varies between different elements in the group. $\mathrm{Al}, \mathrm{Na}$, and $\mathrm{K}$ all display maxima at the top of the metalliferous unit, $\mathrm{Mg}$ reaches a maximum at the base of the unit, and the two Si peaks have approximately the same amplitude. This indicates that there are at least two separate mineral phases controlling the interelement variation within the aluminosilicate group. Concentrations of $\mathrm{Al}, \mathrm{Fe}, \mathrm{Mg}, \mathrm{Na}$, and $\mathrm{K}$ are higher in the Eocene limestone beneath the metalliferous unit than in the Oligocene chalk above. The underlying basalt (Fig. 2 and Appendix D) is strongly enriched in $\mathrm{Al}, \mathrm{Mg}$, and $\mathrm{Na}$ relative to the sediments.

The $\mathrm{HCl}$-soluble values (Fig. 2 and Appendix A) do not simply follow the whole-sediment data. Fe and Mn have very different distributions (see below) indicating the presence of separate $\mathrm{Fe}$ - and $\mathrm{Mn}$-bearing minerals. Smaller proportions of the total $\mathrm{Al}, \mathrm{Na}$, and $\mathrm{K}$ are $\mathrm{HCl}$ soluble in the upper part of the metalliferous unit, confirming the presence of two distinct aluminosilicate phases.

When expressed on a carbonate-free basis (Fig. 2), the whole-sediment data display essentially the same relationships within the metalliferous unit but the aluminosilicate group peaks are shifted even closer toward the top and bottom of the unit. The CFB data confirm that the noncarbonate component of the Eocene limestone is enriched in $\mathrm{Al}, \mathrm{Fe}, \mathrm{Mg}$, and $\mathrm{K}$ relative to the Oligocene chalks.

Bivariate statistical analysis of the primary whole-sediment data (Table 1) demonstrates a strong negative correlation of all elements with $\mathrm{Ca}$ that overshadows the interrelationships between other elements. (Only samples of metalliferous sediment [522.25-526.45 m sub-bottom

Table 1. Correlation coefficients for major elements in metalliferous sediments at Site 573 .

\begin{tabular}{lrcrrrrrrr}
\hline & $\mathrm{SiO}_{2}$ & $\mathrm{Al}_{2} \mathrm{O}_{3}$ & $\mathrm{Fe}_{2} \mathrm{O}_{3}$ & $\mathrm{MnO}$ & $\mathrm{MgO}$ & $\mathrm{CaO}$ & $\mathrm{Na}_{2} \mathrm{O}$ & $\mathrm{K}_{2} \mathrm{O}$ & $\mathrm{P}_{2} \mathrm{O}_{5}$ \\
\hline $\mathrm{SiO}_{2}$ & & & & & & & & & \\
$\mathrm{Al}_{2} \mathrm{O}_{3}$ & 0.67 & & & & & & & & \\
$\mathrm{Fe}_{2} \mathrm{O}_{3}$ & 0.77 & 0.54 & & & & & & & \\
$\mathrm{MnO}$ & 0.68 & - & 0.98 & & & & & & \\
$\mathrm{MgO}$ & 0.97 & - & 0.74 & 0.66 & & & & & \\
$\mathrm{CaO}$ & -0.95 & -0.67 & -0.93 & -0.87 & -0.91 & & & \\
$\mathrm{Na}_{2} \mathrm{O}$ & 0.95 & 0.81 & 0.69 & 0.58 & 0.86 & -0.88 & & & \\
$\mathrm{~K}_{2} \mathrm{O}$ & 0.87 & 0.91 & 0.77 & 0.67 & 0.73 & -0.88 & 0.93 & & \\
$\mathrm{P}_{2} \mathrm{O}_{5}$ & 0.61 & 0.68 & 0.88 & 0.85 & - & -0.80 & 0.65 & 0.81 & \\
\hline
\end{tabular}

Note: Sample population $=18$. Minimum significant correlation at $99 \%$ confidence level $=0.50$; - indicates correlation coefficient is $<0.50$. 
depth; Appendix A, Samples 573B-42-2, $25-26 \mathrm{~cm}$ to $42-4,125-126 \mathrm{~cm}$ ] were used in the bivariate analysis because the inclusion of other sediment types causes the correlation coefficients to be biased toward samples with large CFB recalculation factors or to be masked by a negative correlation with biogenic silica.) When recalculated on a CFB (Table 2), it can be demonstrated that Fe is strongly positively correlated with $\mathrm{Mn}$ and weakly positively associated with $\mathrm{P}$ and that this group is negatively correlated with the other major elements. $\mathrm{Si}$ is positively correlated with $\mathrm{Al}, \mathrm{Mg}$, and $\mathrm{K}$, but $\mathrm{Al}$ variation does not correlate significantly with $\mathrm{Mg}$; $\mathrm{Na}$ does not correlate significantly with any other element.

\section{Trace Elements}

The stratigraphic distribution of trace element data (Figs. 3 and 4 and Appendixes $\mathrm{A}$ and $\mathrm{C}$ ) corresponds closely with the major element groups. $\mathrm{B}, \mathrm{Co}, \mathrm{Cr}, \mathrm{Cu}$, $\mathrm{Ni}, \mathrm{V}$, and $\mathrm{Zn}$ have similar distributions to the ferromanganese group. $\mathrm{Li}$ and $\mathrm{Ti}$ have strongly bimodal distributions with peaks of approximately equal amplitude; Sc has a bimodal distribution that reaches a maximum at the top of the metalliferous unit. The peaks of the bimodally distributed elements correspond in position with those of the aluminosilicate group ( $\sim 523$ and $526 \mathrm{~m}$ subbottom depth) defined by the major element data. Ce, $\mathrm{La}$, and $\mathrm{Y}$ have distributions that correspond most closely to the ferromanganese group but have secondary peaks that match the upper peak of the aluminosilicate group.
Table 2. Correlation coefficients for major elements in Site 573 metalliferous sediments recalculated on a carbonate-free basis.

\begin{tabular}{lrrrrrrrr}
\hline & $\mathrm{SiO}_{2}$ & $\mathrm{Al}_{2} \mathrm{O}_{3}$ & $\mathrm{Fe}_{2} \mathrm{O}_{3}$ & $\mathrm{MnO}$ & $\mathrm{MgO}$ & $\mathrm{Na}_{2} \mathrm{O}$ & $\mathrm{K}_{2} \mathrm{O}$ & $\mathrm{P}_{2} \mathrm{O}_{5}$ \\
\hline $\mathrm{SiO}_{2}$ & & & & & & & & \\
$\mathrm{Al}_{2} \mathrm{O}_{3}$ & 0.63 & & & & & & & \\
$\mathrm{Fe}_{2} \mathrm{O}_{3}$ & -0.83 & -0.70 & & & & & & \\
$\mathrm{MnO}_{1}$ & -0.85 & -0.75 & 0.97 & & & & & \\
$\mathrm{MgO}$ & 0.83 & - & -0.59 & -0.59 & & & & \\
$\mathrm{Na}_{2} \mathrm{O}$ & - & - & -0.51 & -0.55 & - & & & \\
$\mathrm{K}_{2} \mathrm{O}$ & 0.73 & 0.93 & -0.66 & -0.71 & - & - & & \\
$\mathrm{P}_{2} \mathrm{O}_{5}$ & -0.66 & - & 0.52 & - & -0.91 & - & - & \\
\hline
\end{tabular}

Note: Sample population $=18$. Minimum significant correlation at $99 \%$ confidence level $=0.50 ;-$ indicates correlation coefficient is $<0.50$.

$\mathrm{Sr}$ has a distribution that is similar to $\mathrm{Ca}$, but it is strongly depleted in the Eocene limestone and enriched in the upper part of metalliferous unit. $\mathrm{Ba}$ has an irregular distribution that does not relate closely to any other element; it reaches its highest concentration toward the base of the metalliferous sediments. The basalt is strongly enriched in $\mathrm{Cr}, \mathrm{Sc}$, and $\mathrm{Ti}$ relative to the overlying sediments.

The HCl-soluble distributions (Figs. 3 and 4 and Appendix A) broadly follow the whole-sediment values. $\mathrm{Ti}$ is relatively insoluble but $\mathrm{Cu}, \mathrm{Ni}$, and $\mathrm{Zn}$ are highly soluble in $\mathrm{HCl}$. Other elements show intermediate solubilities.

The CFB recalculated data (Figs. 3 and 4 ) display significantly different distributions. $\mathrm{B}, \mathrm{Cu}, \mathrm{Ni}, \mathrm{V}, \mathrm{Zn}$, and, to a lesser extent, $\mathrm{Co}$ and $\mathrm{Cr}$ all have high values in the

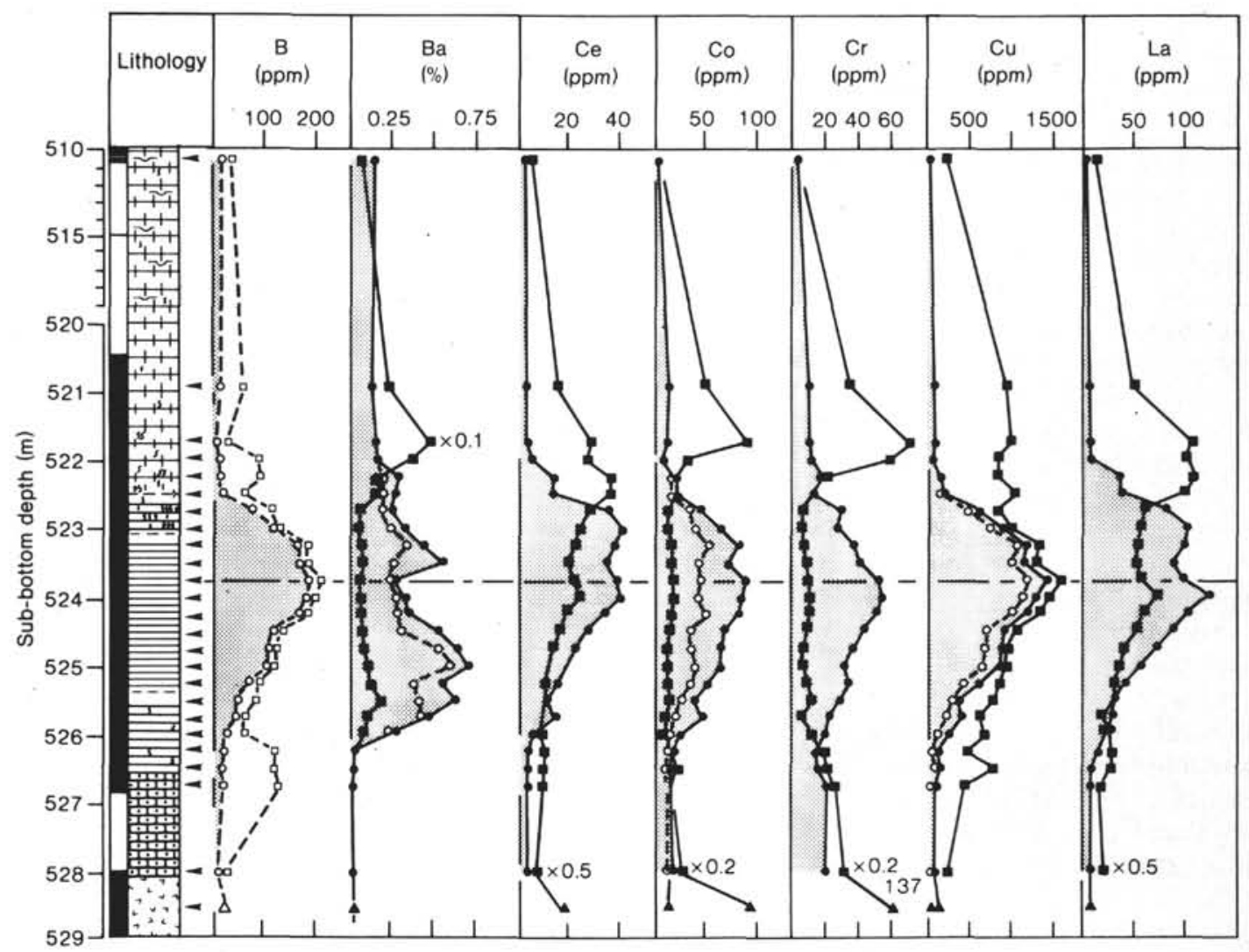

Figure 3. Stratigraphic variation of $\mathrm{B}, \mathrm{Ba}, \mathrm{Ce}, \mathrm{Co}, \mathrm{Cr}, \mathrm{Cu}$, and $\mathrm{La}$ in metalliferous sediments and associated lithologies, Site 573. Open squares are $\mathrm{HCl}$-soluble values recalculated on a CFB; vertical scale and other symbols as in Figure 2. 


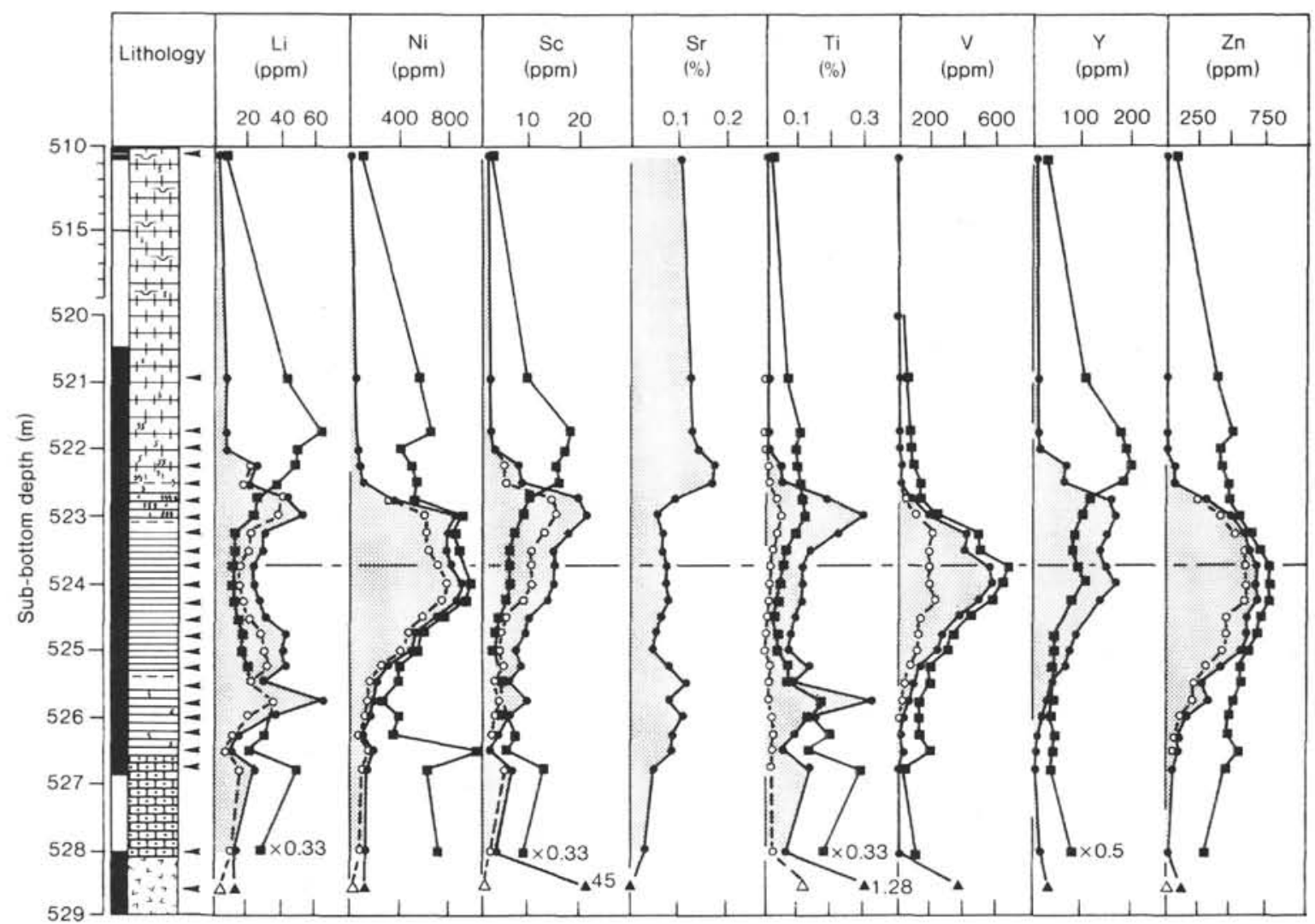

Figure 4. Stratigraphic variation of $\mathrm{Li}, \mathrm{Ni}, \mathrm{Sc}, \mathrm{Ti}, \mathrm{V}, \mathrm{Y}$, and $\mathrm{Zn}$ in metalliferous sediments and associated lithologies at Site 573. Vertical scale and symbols as in Figure 2.

middle of the metalliferous sediment unit relative to its top and base, confirming a correlation with the ferromanganese component. $\mathrm{Ce}, \mathrm{La}, \mathrm{Sc}$, and $\mathrm{Y}$ are strongly enriched in the noncarbonate fraction at the top of the metalliferous unit relative to its middle and base. $\mathrm{Cr}$ and $\mathrm{Li}$ values expressed on a CFB are higher at the base and top of the metalliferous sediments than in the middle, which indicates a correlation with the aluminosilicate group of the major element data. Ti values increase markedly toward the base of the succession. The noncarbonate fraction in the Eocene limestone is enriched in $\mathrm{Cr}, \mathrm{Li}, \mathrm{Sc}$, and $\mathrm{Ti}$ relative to that in the metalliferous sediments. $\mathrm{Ba}, \mathrm{Co}, \mathrm{Cr}, \mathrm{La}, \mathrm{Li}, \mathrm{Sc}$, and $\mathrm{Y}$ are all strongly enriched in the noncarbonate fraction of the three samples from immediately above the metalliferous unit. This trend must be interpreted with caution, however, because these samples have very high Ca values $\left(>94 \% \mathrm{CaCO}_{3}\right)$, which may have resulted in an overestimation of the $\mathrm{CFB}$ values at this level.

Bivariate analysis of the trace element data (Table 3) from the metalliferous sediments demonstrates strong negative correlations between $\mathrm{Ca}$ and all trace elements except $\mathrm{Sr}$ (which co-varies), $\mathrm{Li}$, and $\mathrm{Ti}$ (both of which show no significant correlation). $\mathrm{Fe}$ and $\mathrm{Mn}$ have very strong positive correlations (coefficients of $>0.90$ ) with $\mathrm{Co}, \mathrm{Cr}, \mathrm{Cu}, \mathrm{Ni}, \mathrm{V}$, and $\mathrm{Zn}$ (Fig. 5) and are also both significantly positively correlated with $\mathrm{Ce}, \mathrm{La}$, and $\mathrm{Y}$. Correlation of the $\mathrm{HCl}$-soluble data displays essentially the same trends (Fig. 5), but the correlation between Mn and $\mathrm{Fe}$ is much poorer, suggesting that the elements oc- cur in different mineral phases. $\mathrm{P}$ correlates best with $\mathrm{Ce}, \mathrm{Co}, \mathrm{Cu}, \mathrm{La}, \mathrm{Ni}, \mathrm{V}$, and $\mathrm{Y}$. $\mathrm{Al}$ and $\mathrm{K}$ co-vary with Sc (Fig. 6). The elements $\mathrm{Ba}, \mathrm{Li}$, and Ti correlate only weakly with each other and other elements, but most trace elements exhibit strong positive interelement correlations.

When trace element data are recalculated on a CFB (Table 4), the number of significant correlations is greatly reduced and many elements display negative rather than positive coefficients. $\mathrm{Fe}$ and $\mathrm{Mn}$ retain significant positive correlations with only $\mathrm{B}, \mathrm{Cu}, \mathrm{Ni}, \mathrm{V}$, and $\mathrm{Zn}$ and show significant negative correlations with $\mathrm{Li}, \mathrm{Sc}$, and Ti. Either $\mathrm{Al}$ or $\mathrm{K}$ (and sometimes both) are positively correlated with $\mathrm{Ce}, \mathrm{Co}, \mathrm{Cr}, \mathrm{Li}, \mathrm{Sc}, \mathrm{Ti}$, and $\mathrm{Y}$ and have negative coefficients with $\mathrm{V}$ and $\mathrm{Zn}$. Both $\mathrm{Si}$ and $\mathrm{Mg}$ positively correlate with $\mathrm{Li}$ and $\mathrm{Ti}$ and negatively correlate with $\mathrm{B}, \mathrm{Cu}, \mathrm{V}$, and $\mathrm{Zn}$. $\mathrm{P}$ correlates with $\mathrm{B}, \mathrm{Ce}, \mathrm{Cu}$, $\mathrm{La}, \mathrm{Ni}, \mathrm{V}, \mathrm{Y}$, and $\mathrm{Zn}$; Na exhibits no positive trends.

The trace element data can be interpreted within the framework of the groups defined by the major elements. The ferromanganese phases ( $\mathrm{Fe}$ and $\mathrm{Mn}$ ) control the distribution of $\mathrm{B}, \mathrm{Cu}, \mathrm{Ni}, \mathrm{V}$, and $\mathrm{Zn}$ and affect the $\mathrm{Co}$ and $\mathrm{Cr}$ content of the sediment. The minerals represented by the aluminosilicate group $(\mathrm{Si}, \mathrm{Mg}, \mathrm{Al}, \mathrm{Na}$, and $\mathrm{K})$ control the distribution of $\mathrm{Co}$ and $\mathrm{Cr}$. Close examination of the data indicates, however, that the group contains two distinct phases. The first, indicated by the distribution of $\mathrm{Si}$ and $\mathrm{Mg}$, also controls $\mathrm{Li}$ and $\mathrm{Ti}$; the second is defined by $\mathrm{Al}$ and $\mathrm{K}$, which co-vary with $\mathrm{Sc}$. The carbonate phase $(\mathrm{Ca})$ controls only $\mathrm{Sr}$. P is strongly related to the ferromanganese group of elements but also affects 
Table 3. Correlation coefficients for trace elements in Site 573 metalliferous sediments.

\begin{tabular}{|c|c|c|c|c|c|c|c|c|c|c|c|c|c|c|}
\hline & $\mathrm{Ba}$ & $\mathrm{Ce}$ & Co & $\mathrm{Cr}$ & $\mathrm{Cu}$ & $\mathrm{La}$ & $\mathrm{Li}$ & $\mathrm{Ni}$ & Sc & $\mathrm{Sr}$ & $\mathrm{Ti}$ & V & $\mathrm{Y}$ & $\mathrm{Zn}$ \\
\hline $\mathrm{SiO}_{2}$ & 0.69 & 0.70 & 0.78 & 0.63 & 0.72 & 0.67 & 0.70 & 0.67 & 0.60 & -0.70 & 0.52 & 0.55 & 0.65 & 0.82 \\
\hline $\mathrm{Al}_{2} \mathrm{O}_{3}$ & - & 0.87 & 0.66 & - & 0.64 & 0.74 & 0.55 & 0.68 & 0.96 & - & 0.80 & - & 0.81 & 0.56 \\
\hline $\mathrm{Fe}_{2} \mathrm{O}_{3}$ & 0.51 & 0.81 & 0.99 & 0.94 & 0.98 & 0.87 & - & 0.92 & 0.54 & -0.64 & - & 0.95 & 0.77 & 0.99 \\
\hline $\mathrm{MnO}$ & - & 0.74 & 0.96 & 0.96 & 0.96 & 0.84 & - & 0.89 & - & -0.59 & - & 0.96 & 0.72 & 0.97 \\
\hline $\mathrm{MgO}$ & 0.77 & 0.56 & 0.71 & 0.57 & 0.64 & 0.56 & 0.68 & 0.57 & - & -0.73 & - & - & 0.50 & 0.79 \\
\hline $\mathrm{CaO}$ & -0.64 & -0.82 & -0.93 & -0.82 & -0.90 & -0.83 & - & -0.84 & -0.63 & 0.70 & - & -0.78 & -0.78 & -0.96 \\
\hline $\mathrm{Na}_{2} \mathrm{O}$ & - & 0.77 & 0.73 & 0.57 & 0.70 & 0.71 & 0.70 & 0.68 & 0.76 & -0.61 & 0.60 & 0.50 & 0.73 & 0.74 \\
\hline $\mathrm{K}_{2} \mathrm{O}$ & - & 0.73 & 0.84 & 0.70 & 0.82 & 0.83 & 0.52 & 0.80 & 0.89 & -0.54 & 0.60 & 0.66 & 0.86 & 0.79 \\
\hline $\mathrm{P}_{2} \mathrm{O}_{5}$ & - & 0.92 & 0.91 & 0.88 & 0.93 & 0.94 & - & 0.94 & 0.74 & - & - & 0.90 & 0.92 & 0.86 \\
\hline \multicolumn{15}{|l|}{$\mathrm{Ba}$} \\
\hline $\mathrm{Ce}$ & - & & & & & & & & & & & & & \\
\hline $\mathrm{Co}$ & - & 0.88 & & & & & & & & & & & & \\
\hline $\mathrm{Cr}$ & - & 0.76 & 0.93 & & & & & & & & & & & \\
\hline $\mathrm{Cu}$ & - & 0.89 & 0.99 & 0.94 & & & & & & & & & & \\
\hline $\mathrm{La}$ & - & 0.97 & 0.91 & 0.85 & 0.92 & & & & & & & & & \\
\hline $\mathrm{Li}$ & - & - & - & - & - & - & & & & & & & & \\
\hline $\mathrm{Ni}$ & - & 0.90 & 0.94 & 0.86 & 0.96 & 0.94 & - & & & & & & & \\
\hline $\mathrm{Sc}$ & - & 0.93 & 0.66 & 0.52 & 0.69 & 0.83 & - & 0.71 & & & & & & \\
\hline $\mathrm{Sr}$ & - & - & -0.58 & - & -0.55 & - & - & -0.56 & - & & & & & \\
\hline $\mathrm{Ti}$ & - & - & & - & - & - & 0.77 & - & 0.64 & - & & & & \\
\hline V & - & 0.79 & 0.94 & 0.95 & 0.97 & 0.87 & - & 0.93 & 0.53 & - & - & & & \\
\hline $\mathrm{Y}$ & - & 0.99 & 0.84 & 0.76 & 0.86 & 0.98 & - & 0.88 & 0.91 & - & - & 0.78 & & \\
\hline $\mathrm{Zn}$ & 0.56 & 0.80 & 0.98 & 0.92 & 0.96 & 0.87 & - & 0.91 & 0.55 & -0.66 & - & 0.91 & 0.77 & \\
\hline
\end{tabular}

Note: Sample population $=18$. Minimum significant correlation at $99 \%$ confidence level $=0.50 ;-$ indicates correlation coefficient is $<0.50$.
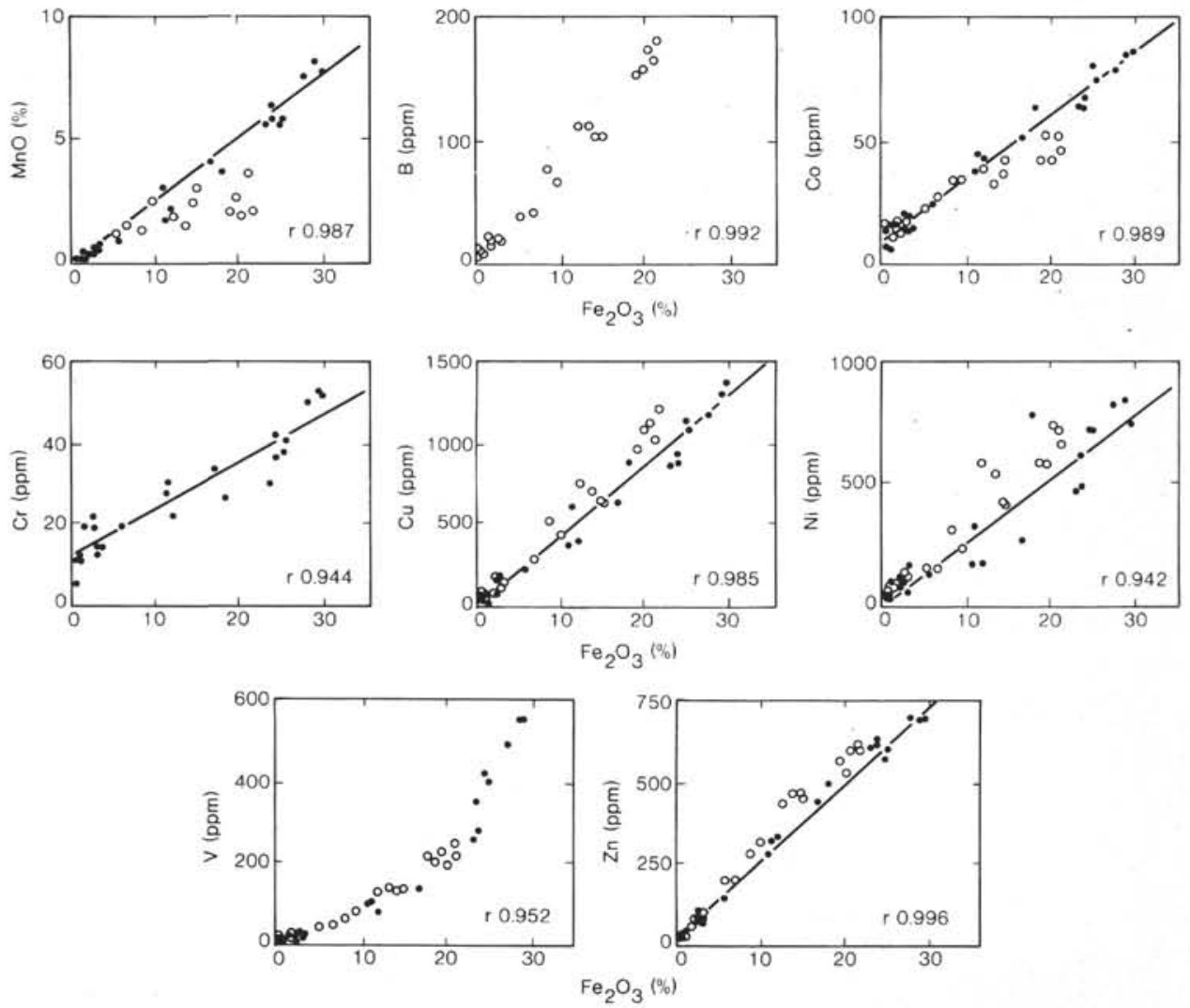

Figure 5. Variation diagrams of $\mathrm{MnO}$ and trace elements $\mathrm{B}, \mathrm{Co}, \mathrm{Cr}, \mathrm{Cu}, \mathrm{Ni}, \mathrm{V}$, and $\mathrm{Zn}$ with $\mathrm{Fe}_{2} \mathrm{O}_{3}$ in basal sediments at Site 573. Dots represent bulk compositions; circles represent $\mathrm{HCl}$-soluble data. Only elements having highly significant correlations with $\mathrm{Fe}_{2} \mathrm{O}_{3}(>0.90)$ are shown. Regression lines and correlation coefficients relate only to bulk compositions; they incorporate all analyses of sediments at Site 573 and consequently differ slightly from those in Tables 1 and 3. 

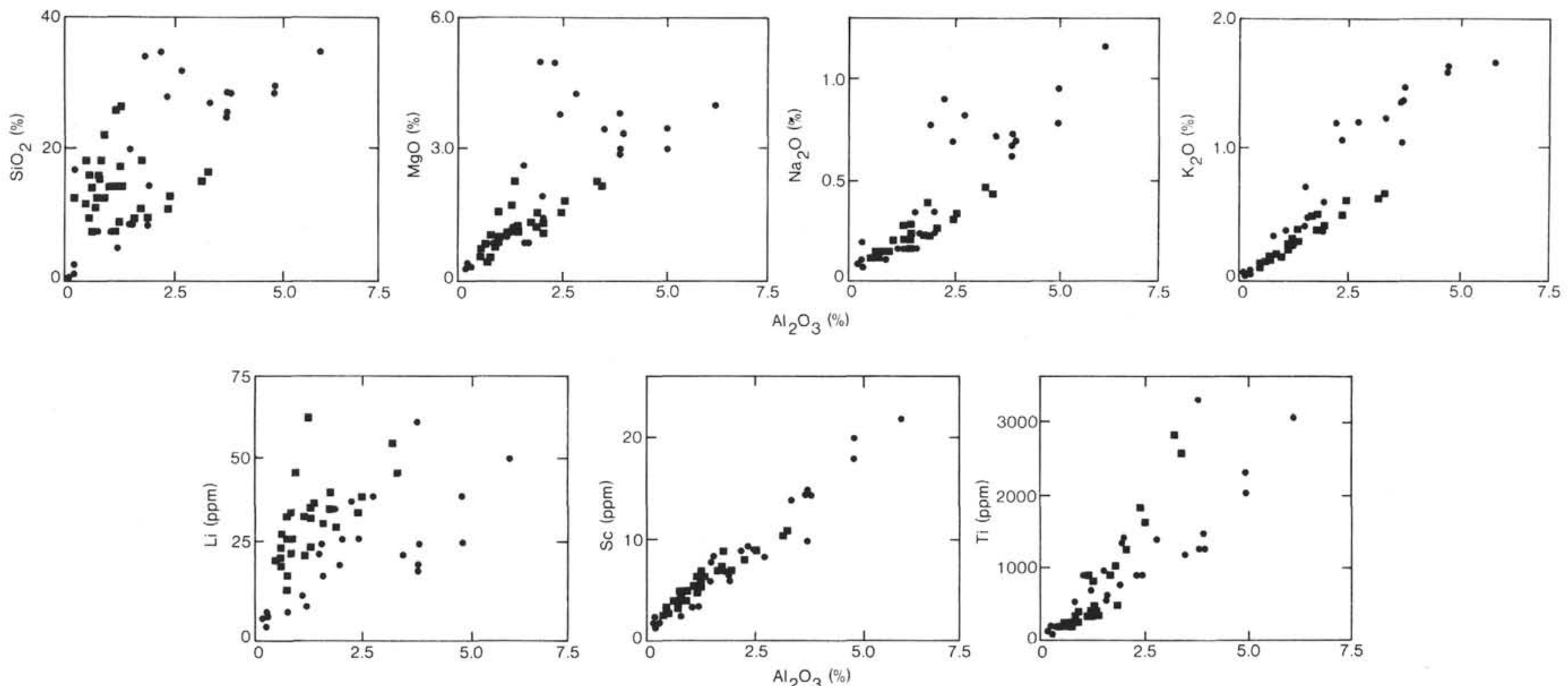

Figure 6. Variation diagrams of some major and trace elements with $\mathrm{Al}_{2} \mathrm{O}_{3}$ in basal sediments from Sites 573 and 574 . Only elements that are strongly associated with $\mathrm{Al}$ are shown. Dots represent bulk compositions from Site 573; filled squares are bulk compositions from Site 574. 
Table 4. Correlation coefficients for trace elements in Site 573 metalliferous sediments recalculated on a carbonate-free basis.

\begin{tabular}{lccllllllllllll}
\hline & $\mathrm{B}$ & $\mathrm{Ba}$ & $\mathrm{Ce}$ & $\mathrm{Co}$ & $\mathrm{Cr}$ & $\mathrm{Cu}$ & $\mathrm{La}$ & $\mathrm{Li}$ & $\mathrm{Ni}$ & $\mathrm{Sc}$ & $\mathrm{Ti}$ & $\mathrm{V}$ & $\mathrm{Y}$ & $\mathrm{Zn}$ \\
\hline $\mathrm{SiO}_{2}$ & -0.77 & - & - & - & 0.55 & -0.81 & - & 0.78 & - & - & 0.75 & -0.89 & - & -0.88 \\
$\mathrm{Al}_{2} \mathrm{O}_{3}$ & - & - & 0.59 & 0.51 & 0.50 & - & - & 0.75 & - & 0.90 & 0.71 & -0.50 & 0.62 & -0.70 \\
$\mathrm{Fe}_{2} \mathrm{O}_{3}$ & 0.86 & -0.50 & - & - & - & 0.74 & - & -0.92 & 0.66 & -0.63 & -0.63 & 0.94 & - & 0.96 \\
$\mathrm{MnO}$ & 0.79 & - & - & - & - & 0.74 & - & -0.90 & 0.62 & -0.63 & -0.73 & 0.92 & - & 0.97 \\
$\mathrm{MgO}$ & -0.79 & - & -0.57 & - & - & -0.92 & -0.58 & 0.51 & -0.52 & - & 0.56 & -0.81 & - & 0.66 \\
$\mathrm{Na}_{2} \mathrm{O}$ & - & - & - & - & - & - & - & - & - & - & - & - & - & - \\
$\mathrm{K}_{2} \mathrm{O}$ & - & - & - & 0.54 & 0.62 & - & - & 0.64 & - & 0.82 & 0.65 & -0.53 & 0.53 & -0.69 \\
$\mathrm{P}_{2} \mathrm{O}_{5}$ & 0.77 & - & 0.59 & - & - & 0.86 & 0.60 & - & 0.64 & - & - & 0.72 & 0.50 & 0.57 \\
$\mathrm{~B}$ & & & & & & & & & & & & & & \\
$\mathrm{Ba}$ & -0.51 & & & & & & & & & & & & & \\
$\mathrm{Ce}$ & - & - & & & & & & & & & & & \\
$\mathrm{Co}$ & - & - & 0.55 & & & & & & & & & & & \\
$\mathrm{Cr}$ & - & - & - & 0.73 & & & & & & & & & & \\
$\mathrm{Cu}$ & 0.84 & - & - & - & - & & & & & & & & & \\
$\mathrm{La}$ & - & 0.50 & 0.97 & 0.63 & - & - & & & & & & & & \\
$\mathrm{Li}$ & -0.77 & 0.56 & - & - & - & -0.63 & - & & & & & & \\
$\mathrm{Ni}$ & 0.74 & -0.53 & - & - & - & 0.67 & - & -0.65 & & & & & & \\
$\mathrm{Sc}$ & - & - & 0.85 & 0.59 & - & - & 0.80 & 0.69 & - & & & & & \\
$\mathrm{Ti}$ & - & - & - & - & - & - & - & -0.65 & - & 0.66 & & & \\
$\mathrm{~V}$ & 0.93 & - & - & - & - & 0.90 & - & -0.83 & 0.70 & - & -0.64 & & & \\
$\mathrm{Y}$ & - & 0.54 & 0.98 & 0.60 & - & - & 0.98 & - & - & 0.89 & - & - & \\
$\mathrm{Zn}$ & 0.81 & - & - & - & - & 0.81 & - & -0.88 & 0.64 & -0.54 & -0.74 & 0.95 & - \\
\hline
\end{tabular}

Note: Sample population $=18$. Minimum significant correlation at $99 \%$ confidence level $=0.50 ;-$ indicates correlation coefficient is $<0.50$. $\mathrm{B}$ is determined from $\mathrm{HCl}$-soluble portion only.

the distribution of $\mathrm{Ce}, \mathrm{La}$, and $\mathrm{Y}$. This suggests the occurrence of a separate P-bearing phase in the sediment. $\mathrm{Ba}$ does not relate to any major or trace element and must also reside in a discrete mineral phase.

\section{Site 574}

Metalliferous sediments recovered from Site 574 do not show the extremes of lithologic variation observed at Site 573. The succession consists of white, siliceous nannofossil chalks underlain by a thick sequence of palebrown, metalliferous, siliceous nannofossil chalks resting on basalt (Figs. 1 and 7). The basal $50 \mathrm{~cm}$ of sediment contains numerous shards of volcanic glass. The metalliferous sediments display relatively little geochemical variation (see Figs. 7-9; Appendix B).

\section{Major Elements}

With the exception of $\mathrm{Si}$ and $\mathrm{Ca}$, most elements display progressive enrichment toward the base of the sediment column (Fig. 7; Appendix B). Differences between the distribution of different elements are less distinct than at Site 573. Ca and $\mathrm{Sr}$ values show small variations that are the inverse of those displayed by other elements. Recalculation of the data on a CFB smooths out minor fluctuations but does not markedly affect the overall trends.

Most elements are enriched below $510 \mathrm{~m}$ sub-bottom depth. $\mathrm{Al}, \mathrm{Na}$, and $\mathrm{K}$ (and to a lesser extent $\mathrm{Fe}$ and $\mathrm{Mg}$ ) all peak at $\sim 505 \mathrm{~m}$ but are highest in the basal $2 \mathrm{~m}$ of sediment. Mn and $\mathrm{P}$ also peak at $\sim 505 \mathrm{~m}$ but exhibit their highest concentrations of $\sim 518 \mathrm{~m}$, tailing-off below that. Si decreases progressively toward the base of the section. $\mathrm{Fe}, \mathrm{Mg}, \mathrm{Mn}$, and $\mathrm{K}$ are less $\mathrm{HCl}$ soluble and $\mathrm{Na}$ is more $\mathrm{HCl}$ soluble in the sediment below $510 \mathrm{~m}$ than above it. This indicates different mineralogic controls on these elements in the upper and lower parts of the section. The basalt (Fig. 7; Appendix D) is strongly enriched in $\mathrm{Si}, \mathrm{Al}, \mathrm{Fe}, \mathrm{Mg}$, and $\mathrm{Na}$ compared with the overlying sediments.

Bivariate analysis of the CFB major element data (Table 5) demonstrates strong negative correlations between $\mathrm{Si}$ and all other elements, which are themselves significantly positively correlated. (Only CFB matrices will be discussed since they differ little from those derived from the primary data, and they were found to be better indicators of mineralogic control at Site 573. Ca has a strong negative correlation with all elements except $\mathrm{Sr}$.) There is evidence, therefore, for discrete carbonate, silica, and "metalliferous" phases, but subdivision of this last category is not possible using the major element analyses.

\section{Trace Elements}

Stratigraphic plots of the trace element data (Figs. 8 and 9; Appendixes B to D) display (with the exception of $\mathrm{Ba}$ and $\mathrm{Sr}$ ) marked enrichments below $\sim 510 \mathrm{~m}$ subbottom depth. This enrichment is greatest for B, Co, $\mathrm{Cu}, \mathrm{Sc}, \mathrm{Ti}, \mathrm{V}$, and $\mathrm{Zn}$. Li, Sc, and Ti all peak at $\sim 505$ $\mathrm{m}$ and increase markedly toward the base in the lowest 2 $\mathrm{m}$ of sediment $(518$ to $520 \mathrm{~m})$. Ti is enriched in the basal sediment by an order of magnitude. These trends correspond to the distribution of $\mathrm{Al}, \mathrm{Na}$, and $\mathrm{K}$ in the sediment. B, Ce, $\mathrm{Cr}, \mathrm{Cu}, \mathrm{La}, \mathrm{Ni}, \mathrm{V}, \mathrm{Y}$, and $\mathrm{Zn}$ also display peaks at $\sim 505 \mathrm{~m}$ but reach their highest concentrations at $\sim 518 \mathrm{~m}$ before tailing-off. This corresponds to the distribution of $\mathrm{Mn}$ and $\mathrm{P}$. Ba does not display any significant trend. Irregularities in the distributions of $\mathrm{Cr}$ are partly related to the low levels of this element in the sediment. Recalculation on a CFB (Figs. 8 and 9) does not significantly alter these trends. The underlying basalt is strongly enriched in $\mathrm{B}, \mathrm{Co}, \mathrm{Cr}, \mathrm{Sc}, \mathrm{Ti}, \mathrm{V}$, and $\mathrm{Zn}$ relative to the sediments.

$\mathrm{Cu}, \mathrm{Ni}, \mathrm{Sc}$, and $\mathrm{Zn}$ are less $\mathrm{HCl}$ soluble in the basal part of the section than in the sediment above. Most of 


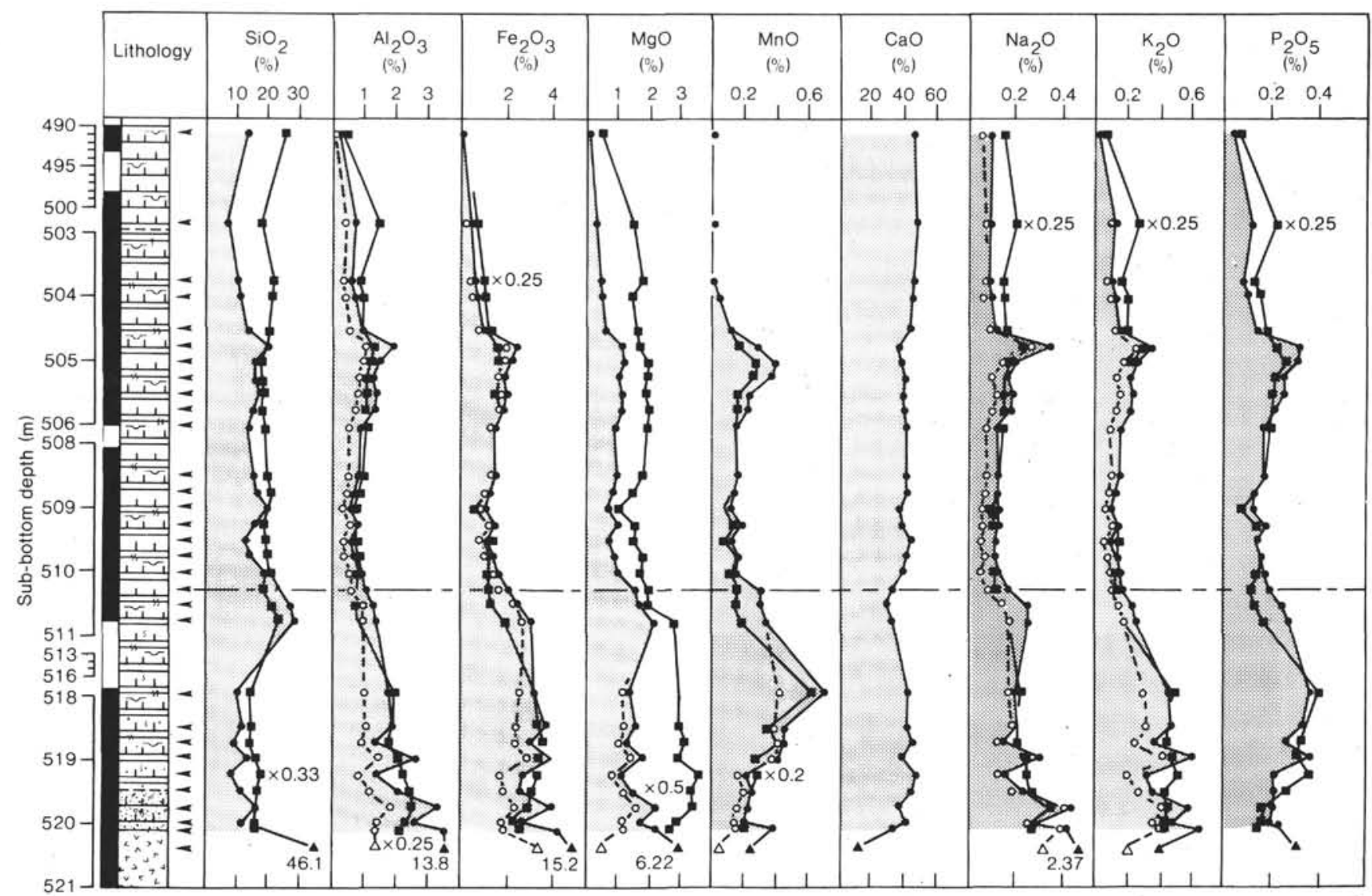

Figure 7. Stratigraphic variations of major elements in metalliferous sediments and associated lithologies at Site 574. Symbols as in Figure 2. The vertical scale is contracted for intervals where no sediment was recovered, allowing easier evaluation of interelement trends.

Table 5. Correlation coefficients for major elements in Site 574 metalliferous sediments recalculated on a carbonate-free basis.

\begin{tabular}{lllllllll}
\hline & $\mathrm{SiO}_{2}$ & $\mathrm{Al}_{2} \mathrm{O}_{3}$ & $\mathrm{Fe}_{2} \mathrm{O}_{3}$ & $\mathrm{MnO}$ & $\mathrm{MgO}$ & $\mathrm{Na}_{2} \mathrm{O}$ & $\mathrm{K}_{2} \mathrm{O}$ & $\mathrm{P}_{2} \mathrm{O}_{5}$ \\
\hline $\mathrm{SiO}_{2}$ & & & & & & & & \\
$\mathrm{Al}_{2} \mathrm{O}_{3}$ & -0.73 & & & & & & & \\
$\mathrm{Fe}_{2} \mathrm{O}_{3}$ & -0.80 & 0.85 & & & & & & \\
$\mathrm{MnO}$ & -0.68 & 0.51 & 0.80 & & & & & \\
$\mathrm{MgO}$ & -0.70 & 0.88 & 0.94 & 0.64 & & & & \\
$\mathrm{Na}_{2} \mathrm{O}$ & -0.56 & 0.92 & 0.69 & - & 0.74 & & & \\
$\mathrm{~K}_{2} \mathrm{O}$ & -0.75 & 0.95 & 0.93 & 0.68 & 0.89 & 0.85 & & \\
$\mathrm{P}_{2} \mathrm{O}_{5}$ & -0.59 & 0.62 & 0.79 & 0.84 & 0.66 & 0.47 & 0.77 & \\
\hline
\end{tabular}

Note: Sample population $=30$. Minimum significant correlation at $99 \%$ confidence level $=0.40 ;-$ indicates correlation coefficient is $<0.40$.

the $\mathrm{Co}, \mathrm{Cu}, \mathrm{Li}$, and $\mathrm{Ni}$ is soluble in $\mathrm{HCl}$ throughout the succession, while $\mathrm{Ti}$ is relatively insoluble.

Bivariate analysis of the CFB data (Table 6) indicates that $\mathrm{Si}$ is either uncorrelated or negatively correlated with all trace elements. Most elements are positively correlated, and it is difficult to differentiate distinct interelement associations. Correlations of $\mathrm{Fe}$ and $\mathrm{Mn}$ with trace elements at Site $\mathbf{5 7 4}$ do not correspond as closely as at Site 573 (Fig. 10). Fe correlates best with B, Co, V, and $\mathrm{Zn}$, and $\mathrm{Mn}$ appears to control $\mathrm{Cu}$ and $\mathrm{Ni}$. Comparison of the interelement correlations of $\mathrm{Fe}$ at Site 573 with those at Site 574 (Fig. 10) indicates very similar linear trends for most elements suggesting that the ferromanganese phases at two sites have comparable mineralogies and diagenetic histories. $\mathrm{Al}$ and $\mathrm{K}$ have strong positive correlations with $\mathrm{Co}, \mathrm{Sc}, \mathrm{Ti}, \mathrm{V}$, and $\mathrm{Zn}$, which also correspond closely to the trends displayed by the aluminosilicate group at Site 573 (Fig. 6). P correlates strongly with $\mathrm{B}, \mathrm{Ce}, \mathrm{Cu}, \mathrm{La}, \mathrm{Ni}, \mathrm{V}, \mathrm{Y}$, and $\mathrm{Zn}$. The absence of clear groups of elements may be attributed to the lack of lithologic end-members in the succession. Further interpretation of the data requires consideration of the mineralogic constraints and comparison with other deposits.

\section{DISCUSSION}

The East Pacific Rise is a relatively young feature (Sclater et al., 1971; Herron, 1972; van Andel et al., 1975). Previously the eastern boundary of the Pacific Plate was located along a series of fossil ridge crests referred to as the Galapagos, Clipperton, and Mathematicians' rises (Fig. 1). Seafloor spreading patterns and other geologic data indicate that these ridges became extinct at 5-12 Ma (van Andel et al., 1975). Basement ages and paleomagnetic data demonstrate that Sites 573 and 574 were located at the ridge crests during the late Eocene (Fig. 1). This is consistent with the hypothesis that the formation of the basal metalliferous sediments at the two sites is related to ridge crest hydrothermal activity (e.g., see Cronan, 1976), but it does not necessarily prove that the sediments were deposited in the immediate vicinity of an active hydrothermal vent system. Metalliferous sediments at Site 573 contain the highest concentra- 


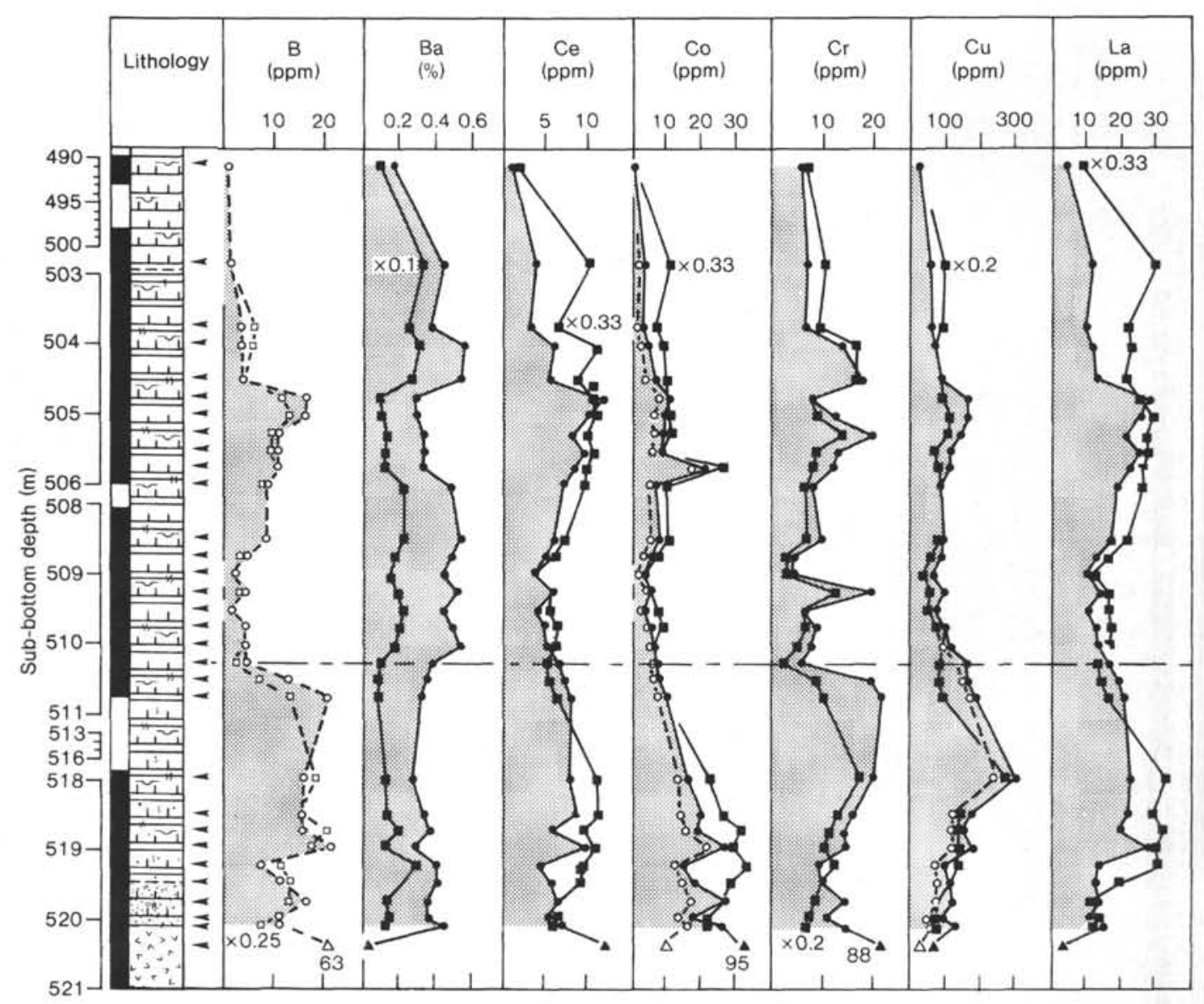

Figure 8. Stratigraphic variation of $\mathrm{B}, \mathrm{Ba}, \mathrm{Ce}, \mathrm{Co}, \mathrm{Cr}, \mathrm{Cu}$, and $\mathrm{La}$ in metalliferous sediments and associated lithologies at Site 574. Open squares are $\mathrm{HCl}$-soluble values recalculated on a $\mathrm{CFB}$; vertical scale and other symbols as in Figure 7.

tion of ferromanganese material but rest on Eocene limestone containing little noncarbonate sediment. Sediments at Site 574 are dominantly pelagic oozes and contain only an accessory ferromanganese component. Comparison with recent metalliferous sediments is necessary to provide a framework to interpret the origin of the Eocene-Oligocene deposits.

\section{Modern Analogs}

Recent metalliferous sediments in the eastern Pacific can be subdivided into three main sediment types based on deposits exemplified by three classic areas: (1) the Galapagos Mounds, (2) the East Pacific Rise, and (3) the Bauer Basin.

\section{Galapagos Mounds Sediments}

The sediments of the Galapagos Mounds (Corliss et al., 1978; Hekinian et al., 1978; Edmond et al., 1979a,b; Williams et al., 1979) are composed dominantly of nontronite-rich, aluminum-poor, Fe smectite sediment in lenticular masses up to a few meters thick and tens of meters across (Honnorez, Von Herzen et al., 1981, 1983). Lenses of nontronite are interbedded with pelagic sediments beneath hydrothermal mounds and ridges 25 to $50 \mathrm{~m}$ across, which form positive topographic features on the seafloor (Klitgord and Mudie, 1974; Lonsdale, 1977). It has been suggested (Corliss et al., 1978; Heki- nian et al., 1978) that nontronite forms from reducing, metal-rich hydrothermal fluids leached from basalt, which replace pelagic sediments during early diagenesis (Honnorez, Von Herzen et al., 1981, 1983; Moorby, 1983). Suboxic conditions below the seafloor (Bender, 1983) result in the mobilization of Mn that has reprecipitated as Mn-oxide crusts near the sediment/water interface. The resulting metalliferous sediments therefore display strong fractionation between the $\mathrm{Fe}$ and $\mathrm{Mn}$ phases. Nontronite-rich layers are strongly enriched in $\mathrm{Si}$ and $\mathrm{Fe}$ but have very low $\mathrm{Al}, \mathrm{Mn}, \mathrm{Ca}$, and trace element contents (Tables 7 and 8 ). Mn crusts are relatively depleted in $\mathrm{Si}$ and $\mathrm{Fe}$ but enriched in $\mathrm{Mn}$ and trace elements (Moorby and Cronan, 1983). Basal sediments are less pure, having substantial $\mathrm{Al}$ contents due to admixture of detrital phases (Varnavas and Cronan, 1981; Moorby and Cronan 1983; Varnavas et al., 1983).

\section{East Pacific Rise Sediments}

The metalliferous sediments of the East Pacific Rise are composed primarily of amorphous ferromanganese oxyhydroxides (Boström and Peterson, 1966; Boström, Peterson, et al., 1969; Boström, Joensuu, et al., 1976; Horowitz, 1970; Bender et al., 1972; Piper, 1973; Dymond and Veeh, 1975; Heath and Dymond, 1977, 1981) that recrystallize to goethite (Marchig and Gundlach, 1982) during early diagenesis. They form extensive de- 


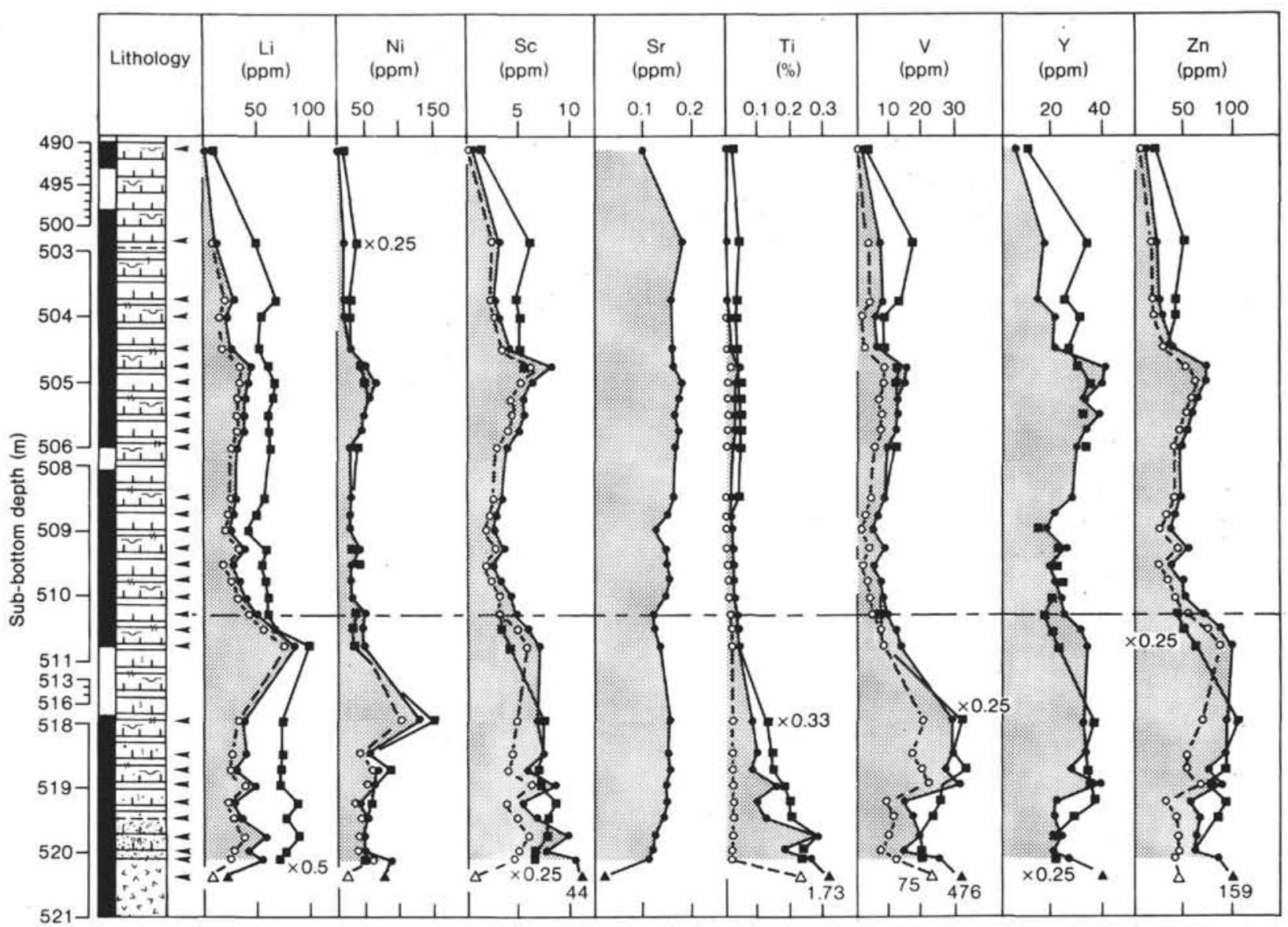

Figure 9. Stratigraphic variation of $\mathrm{Li}, \mathrm{Ni}, \mathrm{Sc}, \mathrm{Sr}, \mathrm{Ti}, \mathrm{V}, \mathrm{Y}$, and $\mathrm{Zn}$ in metalliferous sediments and associated lithologies from Site 574. Vertical scale and symbols as in Figure 7.

Table 6. Correlation coefficients for trace elements in Site 574 metalliferous sediments recalculated on a carbonate-free basis.

\begin{tabular}{|c|c|c|c|c|c|c|c|c|c|c|c|c|c|c|}
\hline & B & $\mathrm{Ba}$ & $\mathrm{Ce}$ & Co & $\mathrm{Cr}$ & $\mathrm{Cu}$ & $\mathrm{La}$ & $\mathrm{Li}$ & $\mathrm{Ni}$ & $\mathrm{Sc}$ & $\mathrm{Ti}$ & $\mathrm{v}$ & $\mathrm{Y}$ & $\mathrm{Zn}$ \\
\hline $\mathrm{SiO}_{2}$ & -0.62 & & -0.41 & -0.72 & - & -0.52 & - & - & -0.62 & -0.67 & -0.68 & -0.68 & - & -0.70 \\
\hline $\mathrm{Al}_{2} \mathrm{O}_{3}$ & 0.68 & & 0.44 & 0.88 & - & 0.47 & - & 0.56 & 0.54 & 0.95 & 0.93 & 0.75 & 0.43 & 0.77 \\
\hline $\mathrm{Fe}_{2} \mathrm{O}_{3}$ & 0.86 & & 0.49 & 0.92 & 0.40 & 0.69 & 0.51 & 0.65 & 0.70 & 0.85 & 0.80 & 0.90 & 0.53 & 0.95 \\
\hline $\mathrm{MnO}$ & 0.80 & & 0.51 & 0.64 & 0.48 & 0.90 & 0.60 & 0.41 & 0.92 & 0.56 & 0.41 & 0.81 & 0.56 & 0.88 \\
\hline $\mathrm{MgO}$ & 0.78 & & - & 0.88 & - & 0.57 & - & 0.80 & 0.57 & 0.86 & 0.86 & 0.78 & 0.41 & 0.90 \\
\hline $\mathrm{Na}_{2} \mathrm{O}$ & 0.60 & & - & 0.74 & - & - & - & 0.44 & 0.41 & 0.86 & 0.88 & 0.61 & - & 0.62 \\
\hline $\mathrm{K}_{2} \mathrm{O}$ & 0.75 & & 0.50 & 0.92 & 0.43 & 0.65 & 0.50 & 0.52 & 0.69 & 0.95 & 0.88 & 0.89 & 0.53 & 0.88 \\
\hline $\mathrm{P}_{2} \mathrm{O}_{5}$ & 0.78 & & 0.77 & 0.72 & 0.58 & 0.90 & 0.88 & 0.46 & 0.82 & 0.75 & 0.41 & 0.89 & 0.86 & 0.92 \\
\hline
\end{tabular}

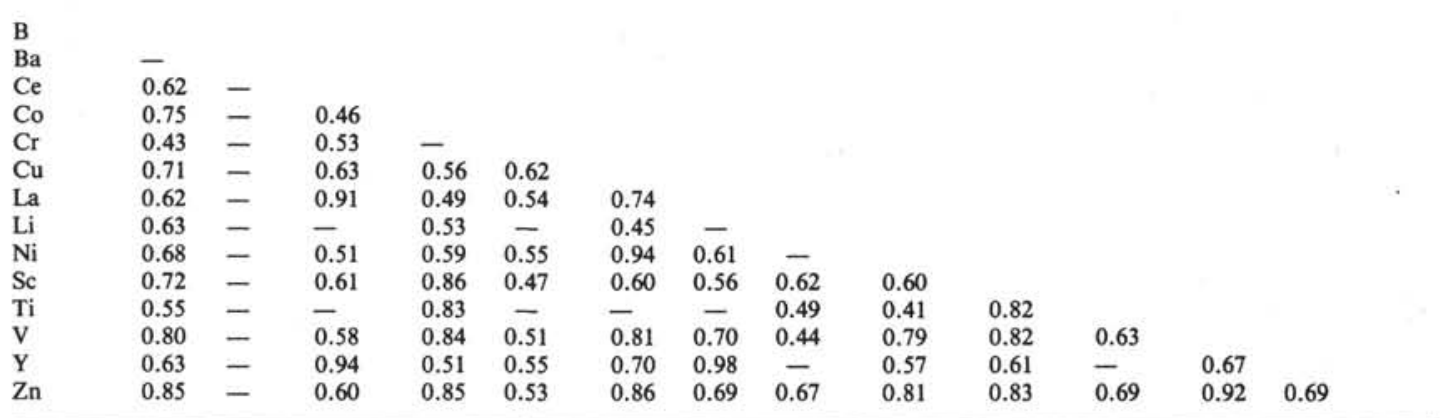

Note: Sample population $=30$. Minimum significant correlation at $99 \%$ confidence level $=0.40 ;-$ indicates correlation coefficient is $<0.40$. B is determined from $\mathrm{HCl}$-soluble portion only. 

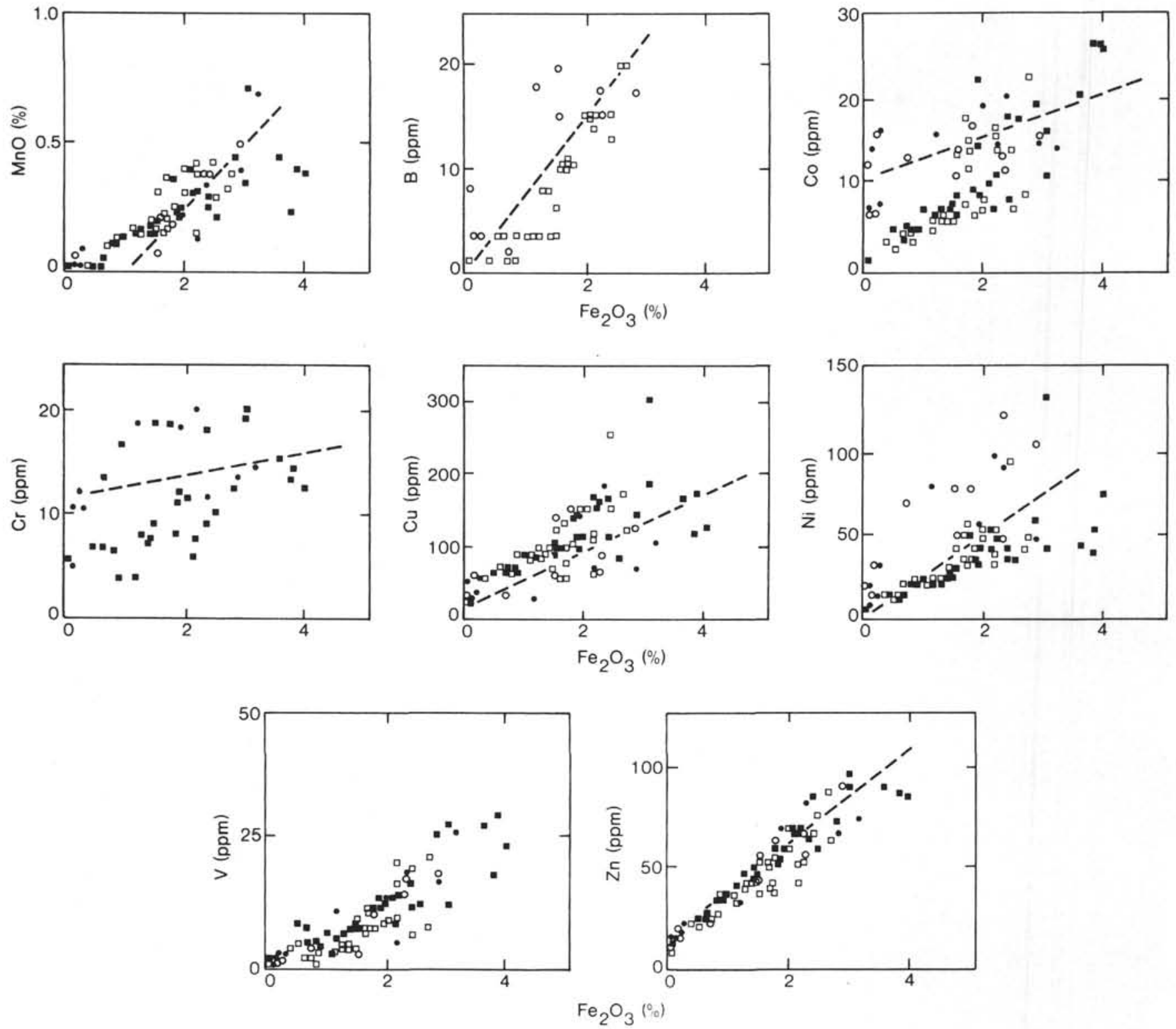

Figure 10. Variation diagrams of $\mathrm{MnO}$ and trace elements $\mathrm{B}, \mathrm{Co}, \mathrm{Cr}, \mathrm{Cu}, \mathrm{Ni}, \mathrm{V}$, and $\mathrm{Zn}$ with $\mathrm{Fe}_{2} \mathrm{O}_{3}$ in basal sediments at Site 574. Filled squares indicate bulk compositions; open squares represent $\mathrm{HCl}$-soluble data. Dots and open circles are corresponding values from sediments at Site 573. Regression lines are based on bulk compositions at Site 573 (Figure 5). There is a strong similarity in the interelement trends between the two sites.

posits on the ridge crest and generally overlie basalt; on the flanks of the ridge they are mixed with increasing amounts of biogenic material and smectite. It is believed (Zelenov, 1964) that the oxyhydroxides form where reducing, metal-rich hydrothermal solutions mix with seawater, producing a precipitate that settles out of suspension. Suboxic diagenesis has resulted in mobilization of some $\mathrm{Mn}$ which is depleted in the lower part of the sediment column (Heath and Dymond, 1981). The predominance of oxyhydroxides is partly related to the high rate of deposition of the metalliferous component (Dymond and Veeh, 1975; McMurtry et al., 1981) on the ridge crest, which swamps biogenic and other particulate phases. The resulting metalliferous sediments are strongly enriched in both $\mathrm{Fe}$ and $\mathrm{Mn}$ but depleted in $\mathrm{Si}$ and $\mathrm{Al}$ relative to other types (Table 7). The sediments of the East
Pacific Rise are enriched in trace elements relative to the Galapagos Mounds nontronites.

\section{Bauer Basin Sediments}

The metalliferous sediments of the Bauer Basin contain up to $90 \%$ Fe smectite (Sayles et al., 1975; Dymond et al., 1976; Dymond and Eklund, 1978; Heath and Dymond, 1977, 1981) mixed with varying proportions of ferromanganese oxyhydroxides and mixed-layer clay minerals (Sayles and Bischoff, 1973; Cronan, 1980; Dymond, 1981; Marchig et al., 1982). They form laterally extensive deposits that accumulate slowly in deep basins immediately below the calcite compensation depth (CCD). The Fe smectite (commonly identified as Fe montmorillonite) is probably authigenic (hydrogenous), formed by a reaction between $\mathrm{Fe}$ oxyhydroxides (brought into the 
Table 7. Major and trace element composition of metalliferous sediments from the eastern Pacific.

\begin{tabular}{|c|c|c|c|c|c|c|c|c|c|}
\hline & \multirow{2}{*}{$\begin{array}{c}\text { Site } 573 \\
\text { basal } \\
n=18 \\
\text { (1) }\end{array}$} & \multirow{2}{*}{$\begin{array}{c}\text { Site } 574 \\
\text { basal } \\
n=28 \\
(2)\end{array}$} & \multirow[b]{2}{*}{$\begin{array}{c}\text { East Pacific } \\
\text { Rise surface } \\
\begin{array}{c}n=20 \\
\text { (3) }\end{array}\end{array}$} & \multicolumn{2}{|c|}{ DSDP Pacific } & \multicolumn{2}{|c|}{ Bauer Deep } & \multicolumn{2}{|c|}{ Galapagos Mounds } \\
\hline & & & & $\begin{array}{c}\text { Basal } \\
n=25 \\
\text { (4) }\end{array}$ & $\begin{array}{c}\text { Basal } \\
n=12 \\
(5)\end{array}$ & $\begin{array}{c}\text { Surface } \\
n=59 \\
(6)\end{array}$ & $\begin{array}{c}\text { Basal } \\
n=11 \\
(7)\end{array}$ & $\begin{array}{c}\text { Nontronite } \\
n=13 \\
(8)\end{array}$ & $\begin{array}{c}\text { Basal } \\
n=9 \\
(9)\end{array}$ \\
\hline \multicolumn{10}{|c|}{ Major elements $(\%)$} \\
\hline $\mathrm{SiO}_{2}$ & 40.30 & 54.80 & 7.49 & 23.10 & 45.60 & 37.40 & 15.00 & 52.60 & 41.30 \\
\hline $\mathrm{Al}_{2} \mathrm{O}_{3}$ & 5.32 & 5.09 & 0.68 & 5.16 & 9.85 & 5.06 & 2.23 & 0.38 & 9.07 \\
\hline $\mathrm{Fe}_{2} \mathrm{OI}_{3}$ & 23.20 & 7.58 & 40.20 & 28.70 & 16.30 & 23.00 & 34.10 & 29.90 & 8.86 \\
\hline $\mathrm{MnO}^{-}$ & 5.21 & 0.91 & 11.90 & 7.83 & 2.08 & 6.73 & 8.37 & 0.04 & 1.03 \\
\hline $\mathrm{MgO}$ & 4.87 & 4.37 & 2.23 & 3.45 & 6.05 & 4.24 & - & 4.30 & 5.31 \\
\hline $\mathrm{CaO}$ & CFB & CFB & CFB & 2.06 & CFB & CFB & CFB & 0.37 & CFB \\
\hline $\mathrm{Na}_{2} \mathrm{O}$ & 0.86 & 0.69 & 0.67 & 3.45 & - & 1.01 & - & 2.51 & - \\
\hline $\mathrm{K}_{2} \mathrm{O}$ & 1.79 & 1.01 & 0.25 & 1.39 & - & 1.06 & - & 3.22 & 1.10 \\
\hline $\mathrm{P}_{2} \mathrm{O}_{5}$ & 2.68 & 0.79 & 2.62 & - & - & - & - & - & 0.41 \\
\hline \multicolumn{10}{|c|}{ Trace elements (ppm) } \\
\hline $\mathrm{Ba}$ & 6150 & 16000 & 2100 & 6230 & 3850 & 19000 & 9250 & 350 & - \\
\hline $\mathrm{Ce}$ & 35 & 24 & 13 & - & - & 51 & 44 & - & - \\
\hline $\mathrm{Co}$ & 85 & 45 & 111 & 82 & 59 & 176 & 134 & - & 50 \\
\hline $\mathrm{Cr}$ & 57 & 45 & 30 & - & - & 32 & 26 & 14 & 110 \\
\hline $\mathrm{Cu}$ & 979 & 461 & 1300 & 790 & 293 & 1160 & 1440 & 20 & 240 \\
\hline $\mathrm{La}$ & 100 & 65 & 107 & - & - & 216 & 144 & - & - \\
\hline $\mathrm{Ni}$ & 608 & 147 & 600 & 460 & 232 & 1010 & 565 & 13 & 260 \\
\hline $\mathrm{Sc}$ & 19 & 20 & - & - & - & 19 & 11 & - & - \\
\hline $\mathrm{Ti}$ & 2460 & 2340 & 300 & - & - & - & - & 120 & 2950 \\
\hline V & 289 & 52 & 1920 & - & - & - & - & 12 & 240 \\
\hline$Y$ & 156 & 99 & 110 & - & - & - & - & - & - \\
\hline $\mathrm{Zn}$ & 590 & 220 & 394 & 470 & 231 & 450 & 555 & 35 & 310 \\
\hline
\end{tabular}

Note: Sources for (1) and (2) this work; (3) Marchig and Gundlach, 1982; (4) Cronan, 1976; (5) Leinen, 1981; (6) Sayles et al., 1975; Dymond et al., 1976; Heath and Dymond, 1981; (7) Dymond et al., 1976; (8) Honnorez et al., 1983; (9) Moorby and Cronan, 1983. $n=$ number of analyses; $\mathrm{CFB}=$ carbonate-free basis; $-=$ not reported.

Table 8. Major element composition of Fe-rich clay minerals from the eastern Pacific.

\begin{tabular}{|c|c|c|c|c|}
\hline $\begin{array}{c}\text { Major } \\
\text { elements } \\
(\%)\end{array}$ & $\begin{array}{c}\text { Average Pacific } \\
\text { clay } \\
\text { (bulk sediment) } \\
n=26 \\
\text { (1) }\end{array}$ & $\begin{array}{l}\text { Northeastern Pacific } \\
\text { Fe montmorillonite } \\
\text { (bulk sediment) } \\
n=5 \\
\text { (2) }\end{array}$ & $\begin{array}{c}\text { Bauer Deep } \\
\text { Fe smectite } \\
\text { (microprobe) } \\
n=10 \\
\text { (3) }\end{array}$ & $\begin{array}{c}\text { Galapagos Mounds } \\
\text { nontronite } \\
\text { (microprobe) } \\
n=11 \\
\text { (4) }\end{array}$ \\
\hline $\mathrm{SiO}_{2}$ & 53.50 & 51.70 & 52.30 & 52.20 \\
\hline $\mathrm{Al}_{2} \mathrm{O}_{3}$ & 17.70 & 8.13 & 2.44 & 0.19 \\
\hline $\mathrm{Fe}_{2} \mathrm{O}_{3}$ & 7.23 & 14.70 & 29.70 & 30.30 \\
\hline $\mathrm{MnO}^{\circ}$ & 0.62 & 0.29 & 0.64 & 0.06 \\
\hline $\mathrm{MgO}$ & 2.92 & 4.21 & 6.10 & 3.90 \\
\hline $\mathrm{CaO}$ & 0.92 & 0.15 & 0.47 & 0.38 \\
\hline $\mathrm{Na}_{2} \mathrm{O}$ & 1.59 & 1.21 & 0.60 & 0.94 \\
\hline $\mathrm{K}_{2} \mathrm{O}$ & 3.23 & 0.71 & 2.04 & 3.74 \\
\hline $\mathrm{P}_{2} \mathrm{O}_{5}$ & 0.24 & nd & nd & nd \\
\hline Total & 87.95 & 81.10 & 94.29 & 91.71 \\
\hline
\end{tabular}

Note: Sources of data are (1) Turekian and Wedephol, 1961; Chester, 1965; Cronan, 1969; (2) Aoki et al., 1974; (3) Dymond and Eklund, 1978; (4) Barrett et al., 1983. $n=$ number of analyses; nd $=$ not determined.

basin by currents from the East Pacific Rise) and biogenic silica (Lyle et al., 1977; Heath and Dymond, 1977; Dymond and Eklund 1978; Bischoff, Heath, et al., 1979; Bischoff, Piper, et al., 1979; Hein et al., 1979; Lyle, 1981). Early diagenesis is oxic, and there is no evidence of Mn migration (Lyle, 1981; Heath and Dymond, 1981). The resulting metalliferous sediments are characterized by $\mathrm{Al}$ contents that are higher than in either nontronites or East Pacific Rise deposits and by intermediate $\mathrm{Si}$ contents (Tables 7 and 8 ). They display the greatest degree of trace element enrichment (Table 7) of the three types, probably because they accumulated more slowly (Dymond and Veeh, 1975; McMurtry et al., 1981) near the sediment/water interface where oxyhydroxides and/or smectite could absorb transition metals from seawater (Toth, 1980). Basal sediments in Bauer Basin directly overlie basalt (Dymond et al., 1976) and have lower $\mathrm{Al}$ and $\mathrm{Si}$ contents (Table 7), suggesting that they are more akin to the East Pacific Rise deposits.

In addition to the three main categories, local seafloor deposits of metal sulfides occur at $21^{\circ} \mathrm{N}$ on the East Pacific Rise (Edmond, Measures, McDuff, et al., 1979; Edmund, Measures, Mangum, et al., 1979; Francheteau et al., 1979; Hekinian et al., 1980), and hydrothermal vents also precipitate sulfides in the Galapagos Mounds Hydrothermal Field (Corliss et al., 1979; Edmond, Measures, Mangum, et al., 1979). These are, however, very localized deposits that are mineralogically distinct from the others considered here. There is no evidence of sulfides in the Leg 85 material. It has been speculated, however, that oxidation of sulfides suspended in the water column provides an alternative mechanism for the formation of dispersed oxyhydroxides (Dymond, 1981; Michard et al., 1983; Shearme et al., 1983).

\section{Mineralogy and Composition}

Comparison between the mineralogy and average CFB bulk chemistry of Leg 85 metalliferous sediments and their modern analogs (Table 7) indicates that the sediments at Site 573 closely resemble those from the Bauer Basin and that they are not dissimilar to basal sediments recovered at other DSDP sites in the eastern Pacific. Metalliferous sediments at Site 574 contain substantially more $\mathrm{Si}$ and are depleted in $\mathrm{Fe}$ and $\mathrm{Mn}$ relative to other sites, reflecting a greater abundance of biogenic silica here. 
The sediments at Sites 573 and 574 contain more $\mathrm{Al}$ than do the Galapagos Mounds or the East Pacific Rise deposits; they are enriched in Si relative to the East Pacific Rise deposits and to most basal sediments, and they are strongly enriched in trace elements compared with the nontronites.

Metalliferous sediments of the Bauer Basin are composed predominantly of $\mathrm{Fe}$ smectite, yet at Site $573 \mathrm{Fe}$ displays a strong negative correlation with $\mathrm{Si}, \mathrm{Al}, \mathrm{Mg}$, $\mathrm{Na}$, and $\mathrm{K}$ in the noncarbonate fraction (Table 2). This apparent anomaly can be explained if the major element data are examined in more detail. Lithostratigraphic analysis has demonstrated that the composition of the noncarbonate fraction varies considerably between the middle and the margins of the metalliferous unit. If representative sample analyses from these three portions (Table 9) are compared with analyses of Fe-rich clay minerals from the eastern Pacific (Table 8), it becomes apparent that the noncarbonate fraction from the base and top of the metalliferous unit has a comparison similar to $\mathrm{Fe}$ montmorillonite from the northeast Pacific (Aoki et al., 1974) but that it contains excess Mn and P. This composition is intermediate between $\mathrm{Fe}$ smectite from the Bauer Basin (Dymond and Eklund, 1978) and average Pacific clay (Turekian and Wedepohl, 1961; Chester 1965; Cronan, 1969).

Sediment from the middle of the metalliferous unit at Site 573 contains a far higher percentage of $\mathrm{Fe}, \mathrm{Mn}$, and $P$ but less of the other major elements than do the top and base of the unit. This difference in composition is

Table 9. Compositional variation in the noncarbonate fraction of metalliferous sediments at Sites 573 and 574.

\begin{tabular}{|c|c|c|c|c|}
\hline & $\begin{array}{c}573 \mathrm{~B}-42-2 \\
50-51 \mathrm{~cm}\end{array}$ & $\begin{array}{c}573 \mathrm{~B}-42-3 \\
25-26 \mathrm{~cm}\end{array}$ & $\begin{array}{l}573 \mathrm{~B}-42-2, \\
125-126 \mathrm{~cm}\end{array}$ & $\begin{array}{r}574 C-35-2 \\
26-27 \mathrm{~cm}\end{array}$ \\
\hline \multicolumn{5}{|c|}{ Major elements $(\%)$} \\
\hline $\mathrm{SiO}_{2}$ & 51.10 & 29.20 & 53.00 & 54.50 \\
\hline $\mathrm{Al}_{2} \mathrm{O}_{3}$ & 9.68 & 4.56 & 7.58 & 9.05 \\
\hline $\mathrm{Fe}_{2} \mathrm{O}_{3}$ & 13.70 & 34.90 & 19.20 & 13.40 \\
\hline $\mathrm{MnO}^{\circ}$ & 1.96 & 9.00 & 2.69 & 1.42 \\
\hline $\mathrm{MgO}$ & 5.05 & 3.34 & 6.34 & 7.42 \\
\hline $\mathrm{Na}_{2} \mathrm{O}$ & 1.12 & 0.77 & 0.90 & 0.97 \\
\hline $\mathrm{K}_{2} \mathrm{O}$ & 2.79 & 1.57 & 2.44 & 2.09 \\
\hline $\mathrm{P}_{2} \mathrm{O}_{5}$ & 2.88 & 4.72 & 1.40 & 1.41 \\
\hline Total & 88.20 & 88.06 & 93.55 & 90.26 \\
\hline \multicolumn{5}{|c|}{ Trace elements (ppm) } \\
\hline B & 61.7 & 212.0 & 118.0 & 43.8 \\
\hline $\mathrm{Ba}$ & 14300.0 & 2780.0 & 366.0 & 28300.0 \\
\hline $\mathrm{Ce}$ & 70.9 & 42.8 & 19.9 & 28.0 \\
\hline Co & 118.0 & 103.0 & 95.8 & 103.0 \\
\hline $\mathrm{Cr}$ & 69.7 & 59.6 & 93.0 & 61.5 \\
\hline $\mathrm{Cu}$ & 1080.0 & 1610.0 & 488.0 & 706.0 \\
\hline $\mathrm{La}$ & 204.0 & 114.0 & 50.6 & 96.9 \\
\hline $\mathrm{Li}$ & 105.0 & 23.3 & 79.2 & 165.0 \\
\hline $\mathrm{Ni}$ & 512.0 & 867.0 & 326.0 & 228.0 \\
\hline $\mathrm{Sc}$ & 46.0 & 16.4 & 21.4 & 34.6 \\
\hline $\mathrm{Ti}$ & 3050.0 & 1360.0 & 5810.0 & 5860.0 \\
\hline v & 112.0 & 649.0 & 111.0 & 101.0 \\
\hline $\mathrm{Y}$ & 348.0 & 173.0 & 85.8 & 146.0 \\
\hline $\mathrm{Zn}$ & 479.0 & 794.0 & 442.0 & 372.0 \\
\hline
\end{tabular}

Note: Total Fe expressed as $\mathrm{Fe}_{2} \mathrm{O}_{3}$; $\mathrm{B}$ determined from $\mathrm{HCl}$-soluble portion only. explained by XRD data that indicate an increased admixture of ferromanganese oxyhydroxides (including goethite and $\delta \mathrm{MnO}_{2}$ ), similar to that in the East Pacific Rise deposits (Table 7). Thus, the oxyhydroxide phases are enriched in $\mathrm{Fe}, \mathrm{Mn}$, and $\mathrm{P}$ but depleted in the other major elements relative to $\mathrm{Fe}$ smectite, resulting in a negative correlation between the two groups of elements. Metalliferous sediments at Site 574 show less variation and have compositions (Tables 7 and 9) that indicate the predominance of $\mathrm{Fe}$ smectite.

It is possible, therefore, to assign most of the $\mathrm{Si}$ in the metalliferous sediments at Site 573 to smectite, which would appear to indicate the virtual absence of biogenic opal. In addition, the $\mathrm{Ca}$ content of the metalliferous claystone is very low (Fig. 2), which indicates that the sediment contains little or no biogenic carbonate, a conclusion confirmed by XRD analysis. This is in sharp contrast to other sediments at the site, which are predominantly biogenic. A decline in the biogenic component could be explained by: (1) a reduced influx of biogenic detritus, (2) increased input of the metalliferous component, (3) dissolution of biogenic silica and carbonate, or (4) a combination of these three processes. Biostratigraphic evidence (Barron et al., this volume) indicates that the metalliferous claystone at Site 573 was deposited at a greatly reduced rate of deposition and probably contains a depositional hiatus corresponding to the Eocene/Oligocene boundary. A comparable hiatus is widespread throughout the Pacific (Kennett et al., 1975), although it apparently does not occur at Site 574. Clearly, a massive influx of ferromanganese oxyhydroxides and Fe smectite did not swamp normal biogenic sedimentation, although fluctuation in the supply of ferromanganese minerals may have been a contributory factor.

The state of preservation of microfossils within the metalliferous sediments at Site 573 indicates that both calcareous (planktonic foraminifers and nannofossils) and siliceous (diatoms and radiolarians) forms have undergone severe dissolution in the transitional sediments and that they are entirely absent in the metalliferous claystone. The claystone contains only an impoverished fauna of benthic foraminifers. A positive correlation between dissolution of microfossils and $\mathrm{Fe}$ content is also apparent at Site 574. It may be concluded that dissolution, probably combined with reduced biogenic sedimentation, was a major process in the formation of these metalliferous sediments.

There is no evidence for a detrital source for Fe smectite (Griffin et al., 1968), and it has been suggested (Lyle et al., 1977; Heath and Dymond, 1977; Dymond and Eklund, 1978; Bischoff et al., 1979; Hein et al., 1979; Lyle, 1981) that the mineral is authigenic, formed by the low-temperature interaction of Fe oxyhydroxides and biogenic silica. This reaction is favored thermodynamically by the high surface energies of oxyhydroxides (Bischoff, Piper, et al., 1979) and has been demonstrated experimentally by Harder (1976). Silica and probably Al are provided by the dissolution of biogenic opal, with other major cations being sequestered from seawater, so that the reaction is limited by the availability of either $\mathrm{Fe}$ 
oxyhydroxide and/or opal. Self-regulation of the reaction may partly explain the gross compositional variation seen at Site 573. It is envisaged that:

1. A gradual reduction in biogenic sedimentation during the latest Eocene, combined with an increased influx of ferromanganese oxyhydroxides, led to the formation of increasing amounts of authigenic Fe smectite in the sediment. Protons formed as a byproduct of the reaction (cf. Honnorez et al., 1981; Honnorez, Von Herzen, et al., 1983; Moorby, 1983) and caused the dissolution of biogenic carbonate.

2. The proportion of oxyhydroxides continued to increase until all biogenic opal was consumed and an excess of ferromanganese oxyhydroxides (goethite and $\delta \mathrm{MnO}_{2}$ ) remained in the sediment. Biogenic carbonate was removed almost completely as a consequence of smectite formation.

3. Biogenic sedimentation increased during the early Oligocene. This was probably coincident with a waning in the supply of oxyhydroxides and led to the return of transitional sediments containing mainly $\mathrm{Fe}$ smectite as the noncarbonate phase.

Excess oxyhydroxide deposition never occurred at Site 574 , which records a simple history of a steadily declining supply of ferromanganese oxyhydroxides.

The presence of two Fe minerals does not explain the strong correlation between $\mathrm{Fe}$ and $\mathrm{Mn}$ in Leg 85 metalliferous sediments, which occurs despite the ease of separation of the two elements by sedimentary processes (Krauskopf, 1957; Bonatti et al., 1972; Elderfield, 1977). Furthermore, partition analysis and mineralogic data indicate that Fe occurs principally in Fe smectite and goethite, while $\mathrm{Mn}$ occurs in $\delta \mathrm{MnO}_{2}$. The association of $\mathrm{Fe}$ and $\mathrm{Mn}$ in the primary oxyhydroxide phase indicates that either they have a common source or, possibly, precipitation of one element catalyzes the precipitation of the other (Cronan, 1980). The smectite structure does not accommodate $\mathrm{Mn}^{4+}$ ions (Weaver and Pollard, 1973); thus Mn must recrystallize into secondary oxide phases on the sediment, either as micronodules or as interlaminations within recrystallized Fe oxyhydroxides. The former process is indicated by the occurrence of micronodules in Leg 85 metalliferous sediments. A strong association of $\delta \mathrm{MnO}_{2}$ with goethite is confirmed by the lower Fe:Mn ratios in the middle of the metalliferous unit at Site 573, but a small amount of $\delta \mathrm{MnO}_{2}$ also co-exists with $\mathrm{Fe}$ smectite and explains the high $\mathrm{Mn}$ content of the transitional sediments. The lack of evidence of $\mathrm{Mn}$ migration during early diagenesis (cf. Bauer Basin) indicates that the sediment remained oxic (Berner, 1981) throughout the history of the two sites.

Biogenic apatite (fish debris) is the main site of $\mathrm{P}$ in pelagic sediments (Arrhenius, 1963), but $\mathrm{P}$ can also be absorbed or co-precipitated on Fe oxyhydroxides (Berner, 1973; Froelich et al., 1977). The positive correlations between $\mathrm{Fe}, \mathrm{Mn}$, and $\mathrm{P}$ at Site 573 (Tables 1 and 2) suggest that the latter may be a significant process. Concentrations of biogenic apatite, however, are common in attenuated successions because of the higher density and lower solubility of apatite compared with calcite. There is a broad correlation between phosphorus content and the proportion of carbonate fluorapatite in Leg 85 sediments, thus it must be concluded that biogenic apatite is the primary site of $P$.

In addition to Fe smectite, partition analysis and statistical data indicate the occurrence of a second aluminosilicate phase distinguished by its effect on $\mathrm{Si}, \mathrm{Mg}, \mathrm{Li}$, and $\mathrm{Ti}$. These elements are most enriched in the noncarbonate fraction of the Eocene limestone and basal metalliferous sediment. Comparison with the composition of the underlying basalt and, in particular, the high $\mathrm{Ti}$ values suggest that this phase is volcanic glass, which is known to be abundant at the bases of both sections.

A final mineral phase indicated by the geochemical data solely affects the distribution of $\mathrm{Ba}$. This has been identified as barite, a common constituent of metalliferous sediments from the eastern Pacific (Heath and Dymond, 1977; Toth, 1980; Dymond, 1981).

\section{Trace Element Partitioning}

Geochemical variation in Leg 85 basalt sediments can be explained in terms of eight main mineral and lithic phases: biogenic calcite and opal, Fe smectite, goethite, $\delta \mathrm{MnO}_{2}$, volcanic glass, barite, and carbonate fluorapatite. The relationship, however, between mineralogy and trace element composition is not always clear.

Fe smectite and ferromanganese oxyhydroxides are both known to strongly partition trace elements (James and MacNaughton, 1977; Hein et al., 1979). My data indicate that the formation of authigenic Fe smectite has relatively little effect on the bulk trace element composition of the sediment. Many elements (B, Co, Cr, Cu, $\mathrm{Ni}$, and $\mathrm{Zn}$ ) show consistent linear trends (Fig. 5) between sediments in which the noncarbonate fraction is mainly Fe smectite (transition sediments) and those containing appreciable goethite (metalliferous claystone). An exception to this is displayed by $\mathrm{V}$, which although correlating strongly with $\mathrm{Fe}$, shows a very sharp upward deflection of the trend line at $\sim 20 \% \mathrm{Fe}_{2} \mathrm{O}_{3}$ (Fig. 5). This suggests that $\mathrm{V}$ is strongly partitioned by goethite.

Statistical and stratigraphic data indicate, however, that $\mathrm{Fe}$ smectite is the main control on the distribution of $\mathrm{Co}$ and $\mathrm{Cr}$, while ferromanganese oxyhydroxides control the distribution of $\mathrm{B}, \mathrm{Cu}, \mathrm{Ni}, \mathrm{V}$, and $\mathrm{Zn}$. The relative effect of goethite and $\delta \mathrm{MnO}_{2}$ on individual trace elements is impossible to gauge from the Leg 85 data because $\mathrm{Fe}$ and $\mathrm{Mn}$ are themselves so strongly correlated. The association between $\mathrm{Sc}$ and $\mathrm{Al}$ indicates that the former element is concentrated during the formation of smectite, although a proportion of both probably resides in volcanic glass. Ti is strongly enriched in the volcaniclastic fraction, but it also occurs, along with $\mathrm{Li}$, in smectite.

$\mathrm{Ca}$ correlates well with $\mathrm{Sr}$, which indicates the presence of $\mathrm{Sr}$ in calcite. There are, however, significant differences between the distributions of $\mathrm{Ca}$ and $\mathrm{Sr}$ at Site 573; $\mathrm{Sr}$ is markedly depleted in the Eocene limestone compared with the Oligocene chalks. Large-scale $\mathrm{Sr}$ depletion such as this has been observed as the normal process that accompanies the dissolution and reprecipitation of pelagic carbonates during burial diagenesis (Matter et al., 1975; Sayles and Manheim, 1975). Thus, the 
low $\mathrm{Sr}$ content of the Eocene limestone reflects its more extensive recrystallization and cementation, probably a consequence of the high heat flow that most likely occurred during the intrusion of the basalt (cf. Scholle, 1974). Late diagenetic depletion of $\mathrm{Sr}$ in pelagic carbonates is accompanied by $\mathrm{Mg}$ enrichment, and this may partly account for the high $\mathrm{Mg}$ content of the Eocene limestone, although volcanic glass and smectite probably provide more significant contributions.

$\mathrm{Ba}$ is believed to occur predominantly in barite. $\mathrm{Ba}$ has strong biogenic associations (Goldberg and Arrhenius, 1958; Church and Wolgemuth, 1972; Boström, 1976; Boström et al., 1978; Gurvich et al., 1978) and is relatively refractory; consequently, it has been suggested (by Heath and Dymond, 1977; Toth, 1980; Dymond, 1981) that $\mathrm{Ba}$ could be utilized as an index of dissolution. $\mathrm{Ba}$ is strongly enriched in metalliferous sediments at Site 573 , but its distribution does not correlate well with the amount of dissolution observed from biogenic particles. This suggests that diagenetic processes have redistributed $\mathrm{Ba}$ prior to the precipitation of barite. Alternatively, its distribution may have been affected by an additional hydrothermal source of $\mathrm{Ba}$ (Arrhenius and Bonatti, 1965; Bonatti et al., 1972; Boström et al., 1973; Bonatti, 1975).

The distributions of the REE (represented by La and $\mathrm{Ce}), \mathrm{Sc}$, and $\mathrm{Y}$ do not compare closely with any single mineral phase. The REE and Y correlate best with $\mathrm{P}$ and are known to be partitioned by biogenic apatite during diagenesis (Dymond and Eklund, 1978), but significant positive correlations with elements controlled by Fe smectite suggest that REE and Y are also associated with the metalliferous component of the sediment. Co-precipitation of REE. with Fe oxyhydroxides is a standard procedure for removing these elements from solution without fractionation (e.g., Elderfield and Greaves, 1982) so their enrichment in metalliferous sediments is not unexpected. The large ionic radii of the REE, Sc, and Y, however, preclude their substitution in either the tetrahedral or octahedral lattice sites of the smectite structure; therefore, they must be released into solution during the formation of $\mathrm{Fe}$ smectite.

The strong enrichment of the REE, Sc, and Y in the noncarbonate fraction at the top of the metalliferous unit at Site 573 can thus be explained by diagenetic processes that accompany the formation of Fe smectite. REE, $\mathrm{Sc}$, and $\mathrm{Y}$ were mobilized during the mineralogic transformation of the ferromanganese component and by the dissolution of biogenic calcite and opal, and they were subsequently assimilated by biogenic apatite (cf. Elderfield et al., 1981). The effectiveness of the absorption process depends on the $\mathrm{pH}$. A low $\mathrm{pH}$ within the metalliferous claystone during early diagenesis is indicated by dissolution of carbonate; this would have inhibited the removal of the REE, Sc, and Y from solution. Buffering associated with the increased carbonate content at the top of the metalliferous sediment would have raised the $\mathrm{pH}$ of the pore water sufficiently to allow more effective removal of the REE, Sc, and Y by biogenic apatite and other phases. Enrichment of the noncarbonate fraction at this level in $\mathrm{Ba}, \mathrm{B}, \mathrm{Co}, \mathrm{Cr}$, and $\mathrm{Li}$ may also be related to the readsorption or co-precipitation of trace elements mobilized during early diagenesis.

Marchig et al. (1982) suggested that hydrothermally dominated metalliferous sediments of the East Pacific Rise can be distinguished from authigenic deposits of the Bauer Basin on the basis of the relationship between the REE, Sc, Y, and P. East Pacific Rise deposits have low REE, Sc, and Y values that do not correlate with $\mathrm{P}$. Bauer Basin deposits have higher REE, Sc, and Y values that correlate with $\mathrm{P}$. This is because in rapidly deposited hydrothermal sediments $\mathrm{P}$ is co-precipitated with $\mathrm{Fe}$ oxyhydroxide (Berner, 1973; Froelich et al., 1977), while in authigenic deposits $\mathrm{P}$ is associated with biogenic apatite that has been enriched in REE by diagenetic processes. Leg 85 metalliferous sediments correspond with the characteristics of the authigenic group, which is consistent with the conclusions derived from the major element data.

\section{Rare Earth Element Patterns}

The REE distributions of recent metalliferous sediments are broadly similar to deep ocean seawater (Bender et al., 1971; Dymond et al., 1973; Piper and Graef, 1974; Toth, 1980; Marchig et al., 1982). They show comparatively little variation despite strong fractionation of the REE (particularly Ce and $\mathrm{Eu}$ ) at different depths in the water column (Elderfield and Greaves, 1982; De Baar et al., 1983). Shale-normalized patterns are characterized by enrichment in the heavy (HREE) relative to the light (LREE) rare earth elements, and they display a marked depletion in $\mathrm{Ce}$ relative to its neighbors $\mathrm{La}$ and Pr. This $\mathrm{Ce}$ anomaly $\left(\mathrm{Ce}^{*}\right)$ can be quantified as:

$$
C e^{*}=\log \left[C e_{\mathrm{sh}} / 1 / 2\left(L a_{\mathrm{sh}}+P r_{\mathrm{sh}}\right)\right]
$$

where $C e_{\text {sh }}, L a_{\text {sh }}$, and $P r_{\text {sh }}$ are the shale normalized values of each element.

Eocene limestone from the base of Site 573 has a low REE content and a pattern $\left(\mathrm{Ce}^{*}=-0.70\right)$ that is very similar to foraminiferal calcite (Elderfield et al., 1981) and oceanic seawater at $\sim 3000 \mathrm{~m}$ depth (Goldberg et al., 1963; Høgdahl et al., 1968; Elderfield and Greaves, 1981, 1982; De Baar et al., 1983). Associated tholeiitic basalts (Appendix D) have higher REE abundances, exhibit no $\mathrm{Ce}$ anomaly, and display less HREE enrichment (Fig. 11). A sample from the top of the Eocene limestone (Sample 573B-42-5, 26-27 cm) also has a smaller $\mathrm{Ce}$ anomaly $\left(\mathrm{Ce}^{*}=-0.44\right)$ and is less enriched in the HREE. The high Ti content of this sample (Fig. 4; Appendix A) indicates the inclusion of a significant quantity of volcanic glass. The REE distribution is the result, therefore, of the primary seawater-like pattern being overprinted by an igneous REE distribution.

The REE patterns of Eocene-Oligocene metalliferous sediments (Appendix C) compare closely to their recent analogs. They are remarkably uniform considering that the absolute concentration of the REE varies by an order of magnitude ( 0.5 to 5 times that of shale) between the margins and center of the metalliferous unit at Site 573 (Figs. 3, 4, and 11). The patterns have strong negative $\mathrm{Ce}$ anomalies $\left(\mathrm{Ce}^{*}=-0.72\right)$ and are slightly en- 


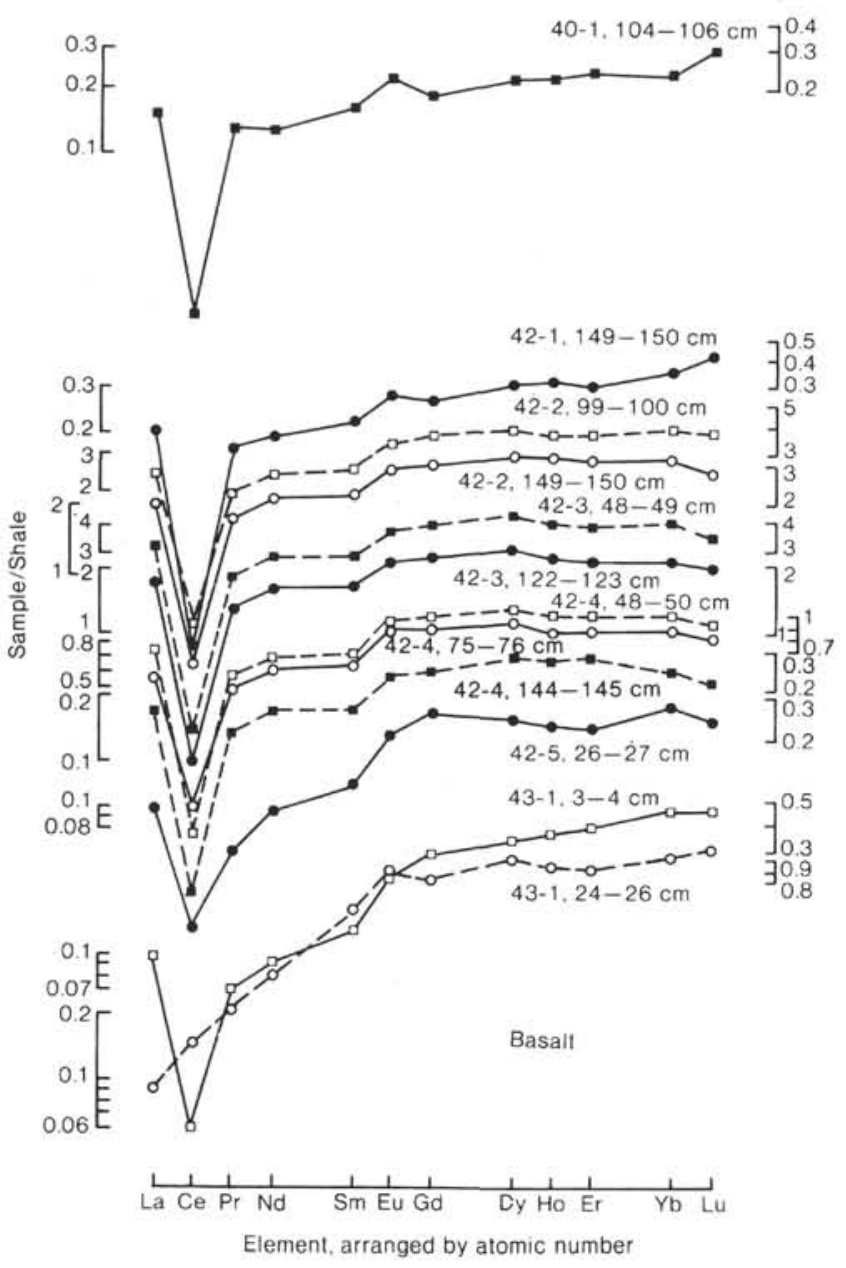

Figure 11. Rare earth element distributions of metalliferous sediments and associated lithologies at Site 573. Values are normalized to average shale (Haskin and Haskin, 1966; Piper 1974b). Samples are plotted stratigraphically to aid the visual separation of patterns; consequently, vertical scales vary. Absolute concentrations are given in Appendix C. Metalliferous sediments from Site 574 display essentially the same trends.

riched in the HREE relative to the LREE. The pattern is similar to sediments of the Bauer Basin type from the flanks of the East Pacific Rise (Piper and Graef, 1974), to authigenic montmorillonite from the southern Pacific (Piper, 1974b), and to ferromanganese nodules and crusts from the Bauer Basin (Elderfield and Greaves, 1981). Metalliferous sediments from the crest of the East Pacific Rise have lower REE contents and show stronger HREE enrichment over the LREE (Piper and Graef, 1974; Marchig et al., 1982). The pattern contrasts markedly with that of pelagic clays (montmorillonite) from the northern Pacific, which have flat patterns with no Ce anomalies (Piper, 1974a,b; Elderfield et al., 1981).

Oligocene chalks have lower REE contents and stronger $\mathrm{Ce}$ anomalies $\left(\mathrm{Ce}^{*}=-0.88\right)$ and are relatively enriched in the HREE compared with metalliferous sediments, although the HREE patterns are flatter than those of the Eocene limestone at Site 573.

Geochemical and mineralogic considerations suggest that the REE were originally sequestered from seawater. A hydrothermal source is rejected because REE distri- butions in hydrothermal solutions from the East Pacific Rise are characterized by large positive Eu anomalies (Michard et al., 1983) and are strongly depleted in the HREE relative to the LREE. Metalliferous sediments with patterns of this type are known from the Red Sea (Courtois and Treuil, 1977). A primary seawater source is also indicated by the ${ }^{143} \mathrm{Nd} /{ }^{144} \mathrm{Nd}$ ratios of metalliferous sediments from the eastern Pacific (O'Nions et al., 1978; Piepgras et al., 1979; Elderfield et al., 1981; Goldstein and O'Nions, 1981), which have seawater values.

The REE, however, are mobilized during early diagenesis (see above) and probably now reside in biogenic apatite. Mobilization of REE also occurs during the formation of ferromanganese nodules (Elderfield and Greaves, 1981, 1982; Elderfield et al., 1981; Murphy and Dymond, 1984) in the northern Pacific. Partition analysis of these nodules (Elderfield et al., 1981) indicates that the REE occur in separate Fe- and P-rich carrier phases. The P-rich phase (in the nodules) is enriched in the HREE relative to the Fe-rich component, which is HREE depleted. By contrast, the flatter pattern of Leg 85 metalliferous sediments compared with other lithologies probably reflects REE fractionation during their incorporation by apatite. Fractionation must be the result of diagenesis because deposits of the East Pacific Rise type, which are composed dominantly of ferromanganese oxyhydroxides, have seawater-like HREE-enriched patterns (Piper and Graef, 1974).

\section{CONCLUSIONS}

Upper Eocene-lower Oligocene metalliferous sediments occur at the base of the sediment columns at Sites 573 and 574 in the central equatorial Pacific. These sediments are strongly enriched in $\mathrm{Fe}, \mathrm{Mn}$, and other transition metals. The deposition of metalliferous sediments is related to the proximity to a source of ferromanganese oxyhydroxides (an active, mid-ocean ridge hydrothermal system) and low biogenic sedimentation rates across the Eocene/Oligocene boundary. Initially high metal contents were enhanced substantially by authigenic and diagenetic processes.

Geochemical and mineralogic data indicate that $\mathrm{Fe}$ smectite is the main $\mathrm{Fe}$-bearing phase in these sediments but that it co-exists with goethite and $\delta \mathrm{MnO}_{2}$. Fe smectite apparently formed by the reaction between hydrothermal ferromanganese oxyhydroxides and biogenic opal but was limited by the availability of opal in the most metalliferous sediments at Site 573. Diagenesis remained oxic. Mn liberated from mixed ferromanganese phases during the formation of smectite was reprecipitated to form $\mathrm{Mn}$ oxyhydroxide micronodules dispersed throughout the sediment. Carbonate was dissolved as a byproduct of smectite formation, producing sediments severely depleted in biogenic material. Most biogenic carbonate and silica was removed in solution from the metalliferous claystone at Site 573. Barite probably formed following the liberation of $\mathrm{Ba}$ absorbed onto biogenic opal.

Metalliferous sediments at Site 574 and transition sediments at Site 573 contain substantially less $\mathrm{Fe}$ and $\mathrm{Mn}$. Here the metalliferous components are diluted by biogenic material (calcite, opal, and apatite) reflecting 
higher rates of biogenic sedimentation. The noncarbonate component, however, is essentially similar to that in more metalliferous sediments. Volcanic glass is an important accessory at the base of both metalliferous successions.

Variations in trace element composition may be explained by a combination of mineralogic controls and diagenetic reactions. Fe smectite exerts a major control on the distribution of $\mathrm{Co}, \mathrm{Cr}$, and $\mathrm{Sc}$, while ferromanganese oxyhydroxides control $\mathrm{B}, \mathrm{Cu}, \mathrm{Ni}, \mathrm{V}$, and $\mathrm{Zn}$. The relative effects of goethite and $\delta \mathrm{MnO}_{2}$ are impossible to gauge because $\mathrm{Fe}$ and $\mathrm{Mn}$ are themselves strongly correlated. Barite controls $\mathrm{Ba}$, calcite controls $\mathrm{Sr}$, and volcanic glass controls $\mathrm{Ti}$ and possibly $\mathrm{Li}$. Strontium depletion in the Eocene limestone at Site $\mathbf{5 7 3}$ is apparently related to recrystallization of carbonate that accompanied the intrusion of basalt.

The REE are strongly enriched in metalliferous sediments. The REE had a seawater source suggesting that they were sequestered by $\mathrm{Fe}$ oxyhydroxides as they precipitated in the water column. The REE were mobilized during early diagenesis and now reside predominantly in a P-rich phase, probably biogenic apatite. The seawaterlike distribution of REE in the primary ferromanganese oxyhydroxides was modified during the formation of smectite resulting in slight depletion in the heavy REE, which remained in solution because of the greater stability of their soluble compounds.

Comparison with recent analogs demonstrates that the Eocene-Oligocene deposits most closely resemble deposits in the Bauer Basin and on the flanks of the East Pacific Rise. This indicates that Sites 573 and 574 were never in close proximity to an active hydrothermal system. Even during the late Eocene, when the sites were located at the ridge crest, they received hydrothermal sediments from another part of the ridge system, possibly several hundred kilometers away. The difference in metal contents between the two sites is related predominantly to differences in local rates of biogenic sedimentation and does not indicate distance from hydrothermal source.

\section{ACKNOWLEDGMENTS}

Dr. Nick Walsh kindly provided the use of the Inductively Coupled Plasma (ICP) Spectrometer at King's College, London, and gave invaluable advice concerning analytical techniques. Laboratory assistance was given by Ms. Siobhan McKeown, Ms. Kym Hockings, and Dr. Alistair Baxter. The work was carried out under the tenure of an ILEA postdoctoral research fellowship at City of London Polytechnic.

\section{REFERENCES}

Aoki, S., Kohyama, N., and Sudo, T., 1974. An iron-rich montmorillonite in a sediment core from the northeastern Pacific. Deep Sea Res., 21:865-875.

Arrhenius, G., 1963. Pelagic sediments. In Hill, M. N. (Ed.), The Sea (Vol. 3): New York (Wiley-Interscience), pp. 655-727.

Arrhenius, G., and Bonatti, E., 1965. Neptunism and volcanoes in the ocean. In Sears, M. (Ed.), Progress in Oceanography: Oxford (Pergamon Press), pp. 7-22.

Barrett, T. J., and Friedrichsen, H., 1982. Element and isotopic compositions of some metalliferous and pelagic sediments from the Galapagos Mounds area, DSDP Leg 70. Chem. Geol., 36:275-298.

Barrett, T. J., Friedrichsen, H., and Fleet, A. J., 1983. Elemental and stable isotopic compositions of some metalliferous and pelagic sediments from the Galapagos Mounds area, Deep Sea Drilling Proj- ect Leg 70. In Honnorez, J., Von Herzen, R. P., et al., Init. Repts. DSDP, 70: Washington (U.S. Govt. Printing Office), 315-323.

Bender, M. L., 1983. Pore-water chemistry, Sites 506-509, Deep Sea Drilling Project. In Honnorez, J., Von Herzen, R. P., et al., Init. Repts. DSDP, 70: Washington (U.S. Govt. Printing Office), 343-353.

Bender, M. L., Brocker, W., Gornitz, V., Middel, U., Kay, R., Sun, S. S., and Biscay, P., 1971. Geochemistry of three cores from the East Pacific Rise. Earth Planet. Sci. Lett., 12:425-433.

Berner, R. A., 1973. Phosphate removal from seawater by adsorption on volcanogenic ferric oxides. Earth Planet. Sci. Lett., 18:77-86. 1981. A new geochemical classification of sedimentary environments. J. Sed. Petrol., 51:359-365.

Bischoff, J. L., Heath, G. R., and Leinen, J., 1979. Geochemistry of deep-sea sediments from the Pacific manganese nodule province: DOMES sites A, B and C. In Bischoff, J. L., and Piper, D. Z. (Eds.), Marine Geology and Oceanography of the Pacific Manganese Nodule Province: New York (Plenum), pp. 397-436.

Bischoff, J. L., Piper, D. Z., and Quinterno, P., 1979. Nature and origin of metalliferous sediment in DOMES site C, Pacific manganese nodule province. In Lalou, C. (Ed.), International Colloquium on the Genesis of Manganese Nodules: Paris (Coll. Int. CNRS), pp. 119-137.

Bonatti, E., 1975. Metallogenesis at oceanic spreading centers. Annu. Rev. Earth Planet. Sci., 3:401-431.

Bonatti, E., Kraemer, T., and Rydell, H., 1972. Classification and genesis of submarine iron-manganese deposits. In Horn, D. R. (Ed.), Ferromanganese Deposits on the Ocean Floor: Washington (NSF), pp. 149-166.

Boström, K., 1976. Particulate and dissolved matter as sources for pelagic sediments. Stockholm Contrib. Geol., 30:15-79.

Boström, K., Joensuu, O., Moore, C., Bostrom, B., Dalziel, K., and Horowitz, A., 1973. Geochemistry of barium in pelagic sediments. Lithos, 6:159-174.

Boström, K., Joensuu, O., Valdes, S., Charm, W., and Glaccum, R., 1976. Geochemistry and origin of east Pacific sediments sampled during DSDP Leg 34. In Yeats, R. S., Hart, S. R., et al., Init. Repts. DSDP, 34: Washington (U.S. Govt. Printing Office), 559-574.

Boström, K., Lysen, L., and Moore, C., 1978. Biological matter as a source of authigenic matter in pelagic sediments. Chem. Geol., 23: 11-20.

Boström, K., and Peterson, M. N. A., 1966. Precipitates from hydrothermal exhalations of the East Pacific Rise. Econ. Geol., 61: 1258-1265.

Boström, K., Peterson, M. N. A., Joensuu, O., and Fisher, D. E., 1969. Aluminium-poor ferromanganese sediments on active ocean ridges. J. Geophys. Res., 74:3261-3270.

Chester, R., 1965. Elemental geochemistry of marine sediments. In Riley, J. P., and Skirrow, G. (Eds.), Treatise on Chemical Oceanography (Vol. 2): New York (Academic Press), pp. 23-80.

Church, T. M., and Wolgemuth, K., 1972. Marine barite saturation. Earth Planet. Sci. Lett., 15:35-44.

Courtois, C., and Treuil, M., 1977. Distribution des terres rares et de quelques éléments en trace dans les sédiments récents des fosses de la Mer Rouge. Chem. Geol., 20:57-72.

Corliss, J. B., 1971. The origin of metal-bearing hydrothermal solutions. J. Geophys. Res., 76:8128-8138.

Corliss, J. B., Dymond, J., Gordon, L. E., Edmond, J. M., Von Herzen, R. P., Ballard, R. D., Green, K., Williams, D., Bainbridge, A. E., Crane, K., and van Andel, T. H., 1979. Submarine thermal springs in the Galapagos Rift. Science, 203:1073-1083.

Corliss, J. B., Lyle, M., Dymond, J., and Crane, K., 1978. The chemistry of hydrothermal mounds near the Galapagos Rift. Earth Planet. Sci. Lett., 40:12-24.

Cronan, D. S., 1969a. Average abundances of Mn, Fe, Ni, Co, Cu, $\mathrm{Pb}, \mathrm{Mo}, \mathrm{V}, \mathrm{Cr}, \mathrm{Ti}$, and $\mathrm{P}$ in Pacific pelagic clays. Geochim. Cosmochim. Acta, 33:1562-1565.

1969b. Interelement associations in some pelagic deposits. Chem. Geol., 5:99-106.

1972. The Mid-Atlantic Ridge near $45^{\circ} \mathrm{N}, \mathrm{XVII}: \mathrm{Al}$, As, $\mathrm{Hg}$, and $\mathrm{Mn}$ in ferruginous sediments from the median valley. Can. J. Earth Sci., 9:319-323. 
1973. Basal ferruginous sediments cored during Leg 16, Deep Sea Drilling Project. In van Andel, T. H., Heath, G. R., et al., Init. Repts. DSDP, 16: Washington (U.S. Govt. Printing Office), 601-604.

1976. Basal metalliferous sediments from the eastern Pacific. Geol. Soc. Am. Bull., 87:928-934.

1980. Underwater Minerals: London (Academic Press).

Cronan, D. S., and Garrett, D. A., 1973. Distribution of elements in metalliferous Pacific sediments collected during the Deep Sea Drilling Project. Nature Phys. Sci., 242:88-89.

Dasch, E. J., Dymond, J. R., and Heath, G. R., 1971. Isotopic analysis of metalliferous sediments from the East Pacific Rise. Earth Planet. Sci. Lett., 13:175-180.

De Baar, H. J. W., Bacon, M. P., and Brewer, P. G., 1983. Rare-earth distributions with a positive Ce anomaly in the western North Atlantic Ocean. Nature, 301:324-327.

Dymond, J., 1981. Geochemistry of Nazca Plate surface sediments: an evaluation of hydrothermal, biogenic, detrital, and hydrogenous sources. Mem. Geol. Soc. Am., 154:133-173.

Dymond, J., Corliss, J. B., Heath, G. R., Field, C. W., Dasch, E. J., and Veeh, H. H., 1973. Origin of metalliferous sediments from the Pacific Ocean. Geol. Soc. Am. Bull., 84:3355-3372.

Dymond, J., Corliss, J. B., and Stillinger, R., 1976. Chemical composition and metal accumulation rates of metalliferous sediments from Sites 319, 320, and 321. In Yeats, R. S., Hart, S. R., et al., Init. Repts. DSDP, 34: Washington (U.S. Govt. Printing Office), 575-588.

Dymond, J., and Eklund, W., 1978. A microprobe study of metalliferous sediment components. Earth Planet. Sci. Lett., 40:243-251.

Dymond, J., and Veeh, H. H., 1975. Metal accumulation rates in the southeast Pacific and the origin of metalliferous sediments. Earth Planet. Sci. Lett., 28:13-22.

Edmond, J. M., Measures, C., McDuff, R. E., Chan, L. H., Collier, R., Grant, B., Gordon, L. I., and Corliss, J. B., 1979. Ridge crest hydrothermal activity and the balances of the major and minor elements in the Ocean: the Galapagos data. Earth Planet. Sci. Lett., 46:1-18.

Edmond, J. M., Measures, C., Mangum, B., Grant, B., Sclater, F. R., Collier, R., Hudson, A., Gordon, L. I., and Corliss, J. B., 1979. On the formation of metal-rich deposits at ridge crests. Earth Planet. Sci. Lett., 46:19-30.

Elderfield, H., 1977. The form of manganese and iron in marine sediments. In Glasby, G. P. (Ed.), Marine Manganese Deposits: Amsterdam (Elsevier), pp. 269-289.

Elderfield, H., and Greaves, M. J., 1981. Negative cerium anomalies in the rare-earth element patterns of oceanic ferromanganese nodules. Earth Planet. Sci. Lett., 55:163-170. 214-219.

1982. The rare-earth elements in seawater. Nature, 296:

Elderfield, H., Hawkesworth, C. J., Greaves, M. J., and Calvert, S. E., 1981. Rare-earth element geochemistry of oceanic ferromanganese nodules and associated sediments. Geochim. Cosmochim. Acta, 45:513-528.

Field, C. W., Wetherell, D. G., and Dasch, E. J., 1981. Economic appraisal of Nazca Plate metalliferous sediments. Mem. Geol. Soc. Am., 154:315-320.

Francheteau, J., Needham, H. D., Choukroune, P., Juteau, P., Seguret, M., Ballard, R. D., Fox, P. J., Normark, W., Carranza, A., Cordoba, D., Guerrero, J., Rangin, C., Bougault, H., Cambon, O., and Hekinian, R., 1979. Massive deep-sea sulphide ore deposits discovered on the East Pacific Rise. Nature, 227:523-528.

Froelich, P. N., Bender, M. L., and Heath, G. R., 1977. Phosphate accumulation rates in metalliferous sediments on the East Pacific Rise. Earth Planet. Sci. Lett., 34:351-359.

Goldberg, E. D., and Arrhenius, G. O. S., 1958. Chemistry of Pacific pelagic sediments. Geochim. Cosmochim. Acta, 13:153-212.

Goldberg, E. D., Koide, M., Schmitt, R. A., and Smith, R. H., 1963. Rare-earth distributions in the marine environment. J. Geophys. Res., 68:4209-4217.

Goldstein, S. L., and O'Nions, R. K., 1981. Nd and Sr isotopic relationships in pelagic clays and ferromanganese deposits. Nature, 292:324-327.

Griffin, J. J., Windom, H., and Goldberg, E. D., 1968. The distribution of clay minerals in the World Ocean. Deep Sea Res., 15: 433-459.
Gurvich, Y. G., Boganov, Y. A., and Lisitsin, A. P., 1978. Behaviour of barium in recent sedimentation in the Pacific. Geokhimiya, 3: 359-374.

Harder, H., 1976. Nontronite synthesis at low temperatures. Chem. Geol., 18:169-180.

Haskin, M. A., and Haskin, L. A., 1966. Rare earths in European shales: a redetermination. Sciences, 154:507-509.

Hays, J. D., Cook, H. E., Jenkins, G., Cook, F. M., Fuller, J. T., Goll, R. M., Milow, D., and Orr, W. N., 1972. Init. Repts. DSDP, 9: Washington (U.S. Govt. Printing Office).

Heath, G. R., and Dymond, J., 1977. Genesis and transformation of metalliferous sediments from the East Pacific Rise, Bauer Deep, and Central Basin, northwest Nazca Plate. Geol. Soc. Am. Bull., 88:723-733.

1981. Metalliferous sediment deposition in time and space: East Pacific Rise and Bauer Basin, northern Nazca Plate. Mem. Geol. Soc. Am., 154:175-197.

Hein, J. R., Veh, H. W., and Alexander, E., 1979. Origin of iron-rich montmorillonite from the manganese nodule belt of the north equatorial Pacific. Clays Clay Min., 27:185-194.

Hekinian, R., Rosendahl, B. R., Cronan, D. S., Dmitriev, Y., Fodor, R. V., Goll, R. M., Hoffert, M., Humphris, S. E., Mattey, D. P., Natland, J., Peterson, W., Roggenthen, W., Schrader, E., Scrivastava, R. K., and Warren, N., 1978. Hydrothermal deposits and associated basement rocks from the Galapagos Spreading Center. Oceanol. Acta, 1:473-482.

Herron, E. M., 1972. Seafloor spreading and the Cenozoic history of the east-central Pacific. Geol. Soc. Am. Bull., 83:1671-1692.

Høgdahl, Ø., Melson, S., and Bowen, V., 1968. Neutron activation analysis of lenthanide elements in sea water. Adv. Chem., 73: 308-325.

Honnorez, J., Von Herzen, R. P., Barrett, T., Becker, K., Borella, P., Hubberten, H. W., Jones, S., Karato, S., Laverne, C., Levi, S., Migdisov, A. A., Moorby, S. A., and Schrader, E., 1981. Hydrothermal mounds and young oceanic crust of the Galapagos: preliminary Deep Sea Drilling results, Leg 70. Geol. Soc. Am. Bull., 92:457-472.

Honnorez, J., Von Herzen, R. P., et al., 1983. Init. Repts. DSDP, 70: Washington (U.S. Govt. Printing Office).

Horowitz, A., 1970. The distribution of $\mathrm{Pb}, \mathrm{Ag}, \mathrm{Sn}, \mathrm{Ti}$, and $\mathrm{Zn}$ in sediments on active ocean ridges. Mar. Geol., 9:241-259.

James, P. O., and MacNaughton, M. G., 1977. The adsorption of aqueous heavy metals on inorganic compounds. Geochim. Cosmochim. Acta, 41:1549-1555.

Kennett, J. P., Houtz, R. E., Andrews, P. B., Edwards, A. R., Gostin, V. A., Hajos, M., Hampton, M., Jenkins, D. G., Margolis, S. V., Ovenshine, A. T., and Perch-Nielsen, K., 1975. Cenozoic paleoceanography in the southwest Pacific Ocean, Antarctic glaciation, and the development of the Circum-Antartic current. In Kennett, J. P., Houtz, R. E., et al., Init. Repts. DSDP, 29: Washington (U.S. Govt. Printing Office), 1155-1169.

Klitgord, K. D., and Mudie, J. D., 1974. The Galapagos Spreading Center: a near-bottom geophysical survey. Geophys. J. R. Astron. Soc., 38:563-586.

Krauskopf, K. B., 1957. Separation of manganese and iron in sedimentary processes. Geochim. Cosmochim. Acta, 12:61-84.

Leinen, M., 1981. Metal-rich basal sediments from northeastern $\mathrm{Pa}$ cific Deep Sea Drilling Project sites. In Yeats, R. S., Haq, B. U., et al., Init. Repts. DSDP, 63: Washington (U.S. Govt. Printing Office), 667-676.

Lonsdale, P., 1977. Deep-tow observations at the mounds abyssal hydrothermal field, Galapagos Rift. Earth Planet. Sci. Lett., 36: 92-110.

Lyle, M., 1981. Formation and growth of ferromanganese oxides on the Nazca Plate. Mem. Soc. Am., 154:269-293.

Lyle, M., Dymond, J., and Heath, G. R., 1977. Copper-nickel-enriched ferromanganese nodules and associated crust from the Bauer Basin, northwest Nazca Plate. Earth Planet. Sci. Lett., 35:55-64.

McMurtry, G. M., Veeh, H. H., and Moser, C., 1981. Sediment accumulation rate patterns on the northwest Nazca Plate. Mem. Geol. Soc. Am., 154:211-249.

Marchig, V., and Gundlach, H., 1982. Iron-rich metalliferous sediments on the East Pacific Rise-prototype of undifferentiated metalliferous sediments in divergent plate boundaries. Earth Planet. Sci. Lett., 58:361-382. 
Marchig, V., Gundlach, H., Moller, P., and Schley, F., 1982. Some geochemical indicators for discriminating between diagenetic and hydrothermal metalliferous sediments. Mar. Geol., 50:241-256.

Matter, A., Douglas, R. G., and Perch-Nielsen, K., 1975. Fossil preservation, geochemistry, and diagenesis of pelagic carbonates from Shatsky Rise, northwest Pacific. In Larsen, R. L., Moberly, R., et al., Init. Repts. DSDP, 32: Washington (U.S. Govt. Printing Office), 891-921.

Michard, A., Albarede, F., Michard, G., Minster, J. F., and Charlou, J. L., 1983. Rare-earth elements and uranium in high-temperature solutions from East Pacific Rise hydrothermal vent field $\left(13^{\circ} \mathrm{N}\right)$. Nature, 303:795-797.

Moorby, S. A., 1983. The geochemistry of transitional sediments recovered from the Galapagos Hydrothermal Mounds Field during DSDP Leg 70-implications for mounds formation. Earth Planet. Sci. Lett., 62:367-376.

Moorby, S. A., and Cronan, D. S., 1983. Chemical composition of sediments from Sites 506, 507, 508, and 509, Leg 70, DSDP. In Honnorez, J., Von Herzen, R. P., et al., Init. Repts. DSDP, 70: Washington (U.S. Govt. Printing Office), 269-275.

Murphy, K., and Dymond, J., 1984. Rare earth element fluxes and geochemical budget in the eastern equatorial Pacific. Nature, 307: 444-447.

Murray, J., and Renard, A. F., 1891. Deep Sea Deposits: Report of the Scientific Results of the HMS Challenger, 1873-1876: London (HMSO).

O'Nions, R. K., Carter, S. R., Cohen, R. S., Evensen, N. M., and Hamilton, P. J., 1978. Pb, Nd, and $\mathrm{Sr}$ isotopes in oceanic ferromanganese deposits and ocean floor basalt. Nature, 273:435-438.

Piepgras, D. J., Wasserberg, G. J., and Dasch, E. J., 1979. The isotopic composition of Nd in different ocean masses. Earth Planet. Sci. Lett., 45:223-236.

Piper, D. Z., 1973. Origin of metalliferous sediments from the East Pacific Rise. Earth Planet. Sci. Lett., 19:75-82.

1974a. Rare-earth elements in ferromanganese nodules and other marine phases. Geochim. Cosmochim. Acta, 38:1007-1022. 1974b. Rare-earth elements in sedimentary cycle: a summary. Chem. Geol., 14:285-304.

Piper, D. Z., and Graef, P. A., 1974. Gold and rare-earth elements in sediments from the East Pacific Rise. Mar. Geol., 17:287-297.

Revelle, R., 1944. Marine bottom samples collected in the Pacific Ocean by the Carnegie on its seventh cruise. Carnegie Inst. Washington Publ., 556:1-180.

Sayles, F. L., and Bischoff, J. L., 1973. Ferromanganese sediments in the equatorial east Pacific. Earth Planet. Sci. Lett., 19:330-336.

Sayles, F. L., Ku, T. L., and Bowker, P. C., 1975. Chemistry of ferromanganese sediment of the Bauer Deep. Geol. Soc. Am. Bull., 86: 1423-1431.

Sayles, F. L., and Manheim, F. T., 1975. Interstitial solutions and diagenesis in buried marine sediments: results from the Deep Sea Drilling Project. Geochim. Cosmochim. Acta, 39:103-127.

Scholle, P. A., 1974. Diagenesis of Upper Cretaceous chalks from England, Northern Ireland, and the North Sea. In Hsü, K. J., and Jenkyns, H. C. (Eds.), Pelagic Sediments: On Land and under the Sea, Spec. Publ. Int. Assoc. Sedimentol., 1:177-210.
Sclater, J. G., Andersen, R. N., and Bell, M. L., 1971. Elevation of ridges and evolution of the central eastern Pacific. J. Geophys. Res., 76:7888-7915.

Shearme, S., Cronan, D. S., and Rona, P. A., 1983. Geochemistry of sediments from the TAG hydrothermal field, MAR at latitude $26^{\circ} \mathrm{N}$. Mar. Geol., 51:269-291.

Thompson, G., 1983. Hydrothermal fluxes in the Ocean. In Riley, J. P., and Chester, R. (Eds.), Chemical Oceanography (Vol. 8): London (Academic Press), pp. 271-337.

Toth, J. R., 1980. Deposition of submarine hydrothermal iron and evidence for hydrothermal input of volatile elements to the oceans. Geol. Soc. Am. Bull., 91:44-54.

Tracey, J. I., Jr., Sutton, G. H., et al., 1971. Init. Repts. DSDP, 8: Washington (U.S. Govt. Printing Office).

Turekian, K. K., and Wedepohl, K. H., 1961. Distribution of elements in some major units of the Earth's crust. Bull. Geol. Soc. Am., 72: 175-192.

van Andel, T. H., Heath, G. R., et al., 1973. Init. Repts. DSDP, 16: Washington (U.S. Govt. Printing Office).

van Andel, T. H., Heath, G. R., and Moore, T. C., 1975. Cenozoic history and paleoceanography of the central equatorial Pacific. Mem. Geol. Soc. Am., 143.

Varnavas, S. P., and Cronan, D. S., 1981. Partition geochemistry of sediments from DSDP Site 424 in the Galapagos Hydrothermal Mounds Field. Min. Mag., 44:325-331.

Varnavas, S. P., Moorby, S A., and Cronan, D. S., 1983. Partition geochemistry of sediments from Holes 506 and 509B, DSDP Leg 70. In Honnorez, J., Von Herzen, R. P., et al., Init. Repts. DSDP, 70: Washington (U.S. Govt. Printing Office), 297-302.

von der Borch, C. C., Nesteroff, W. D., and Galehouse, J., 1971. Iron-rich sediments cored during Leg 8 of the Deep Sea Drilling Project. In Tracey, J. I., Jr., Sutton, G. H., et al., Init. Repts. DSDP, 8: Washington (U.S. Govt. Printing Office), 829-835.

von der Borch, C. C., and Rex, R. W., 1970. Amorphous iron oxide precipitates in sediments cored during Leg 5, Deep Sea Drilling Project. In McManus, D. A., Burns, R. E., et al., Init. Repts. DSDP, 5: Washington (U.S. Govt. Printing Office), 541-544.

Walsh, J. N., Buckley, F., Barker, J., 1981. The simultaneous determination of the rare-earth elements in rocks using inductively coupled plasma source spectrometry. Chem. Geol., 33:141-153.

Weaver, C. E., and Pollard, L. D., 1973. The Chemistry of Clay Minerals. New York (Elsevier).

Williams, D. L., Green, K., van Andel, T. H., Von Herzen, R. P., Dymond, J. R., and Crane, K., 1979. The hydrothermal mounds of the Galapagos Rift: observations with DSRV Alvin and detailed heat flow studies. J. Geophys. Res., 84:7467-7484.

Zelenov, K. K., 1964. Iron and manganese in exhalations of the submarine Banu Wuhu Volcano, Indonesia. Akad. Nauk. SSSR Doklady, 155:94-96.

Date of Initial Receipt: 27 September 1983

Date of Acceptance: 3 May 1984 
APPENDIX A

Major and Trace Element Composition of Basal Sediments from Hole 573B

\begin{tabular}{|c|c|c|c|c|c|c|c|c|c|c|c|c|}
\hline & $\begin{array}{c}40-1 \\
104-106 \mathrm{~cm}\end{array}$ & $\begin{array}{c}42-1 \\
45-46 \mathrm{~cm}\end{array}$ & $\begin{array}{c}42-1 \\
125-126 \mathrm{~cm}\end{array}$ & $\begin{array}{c}42-1 \\
149-150 \mathrm{~cm}\end{array}$ & $\begin{array}{c}42-2 \\
25-26 \mathrm{~cm}\end{array}$ & $\begin{array}{c}42-2 \\
50-51 \mathrm{~cm}\end{array}$ & $\begin{array}{c}42-2 \\
76-77 \mathrm{~cm}\end{array}$ & $\begin{array}{c}42-2 \\
99-100 \mathrm{~cm}\end{array}$ & $\begin{array}{c}42-2 \\
125-126 \mathrm{~cm}\end{array}$ & $\begin{array}{c}42-2 \\
149-150 \mathrm{~cm}\end{array}$ & $\begin{array}{c}42-3 \\
25-26 \mathrm{~cm}\end{array}$ & $\begin{array}{c}42-3 \\
48-49 \mathrm{~cm}\end{array}$ \\
\hline \multicolumn{13}{|c|}{ Major elements $(\%)$} \\
\hline $\mathrm{SiO}_{2}$ & 17.00 & 2.64 & 1.59 & 1.57 & 8.23 & 8.86 & 29.00 & 35.00 & 30.30 & 29.50 & 25.20 & 26.50 \\
\hline $\mathrm{Al}_{2} \mathrm{O}_{3}$ & $0.26(0.15)$ & $0.24(0.15)$ & $0.19(0.08)$ & $0.24(0.13)$ & $1.57(0.68)$ & $1.68(0.57)$ & $5.05(2.13)$ & $6.13(2.42)$ & $5.01(1.88)$ & $3.97(1.42)$ & $3.93(1.21)$ & $3.93(1.30)$ \\
\hline $\mathrm{Fe}_{2} \mathrm{O}_{3}$ & $0.10(0.09)$ & $0.30(0.21)$ & $0.16(0.06)$ & $0.25(0.19)$ & $1.97(1.60)$ & $2.37(1.78)$ & $11.20(8.30)$ & $18.20(12.42)$ & $25.20(19.90)$ & $25.40(19.40)$ & $30.10(21.70)$ & $29.50(20.60)$ \\
\hline $\mathrm{MnO}^{\circ}$ & $0.02(0.02)$ & $0.09(0.04)$ & $0.03(0.02)$ & $0.02(0.01)$ & $0.23(0.20)$ & $0.34(0.19)$ & $1.65(1.13)$ & $3.59(1.88)$ & $5.62(2.67)$ & $5.88(2.10)$ & $7.76(1.99)$ & $8.30(1.90)$ \\
\hline $\mathrm{MgO}$ & $0.20(0.20)$ & $0.31(0.29)$ & $0.24(0.20)$ & $0.25(0.23)$ & $0.82(0.75)$ & $0.88(0.71)$ & $3.05(2.33)$ & $4.05(2.75)$ & $3.43(2.58)$ & $3.42(2.65)$ & $2.88(2.15)$ & $3.00(2.21)$ \\
\hline $\mathrm{CaO}$ & 45.20 & 52.70 & 54.30 & 53.50 & 46.10 & 46.30 & 18.20 & 5.26 & 5.44 & 6.93 & 7.70 & 6.78 \\
\hline $\mathrm{Na}_{2} \mathrm{O}$ & $0.15(0.07)$ & $0.07(0.07)$ & $0.06(0.06)$ & $0.06(0.06)$ & $0.14(0.09)$ & $0.20(0.14)$ & $0.90(0.70)$ & $1.11(0.83)$ & $0.72(0.51)$ & $0.66(0.53)$ & $0.67(0.54)$ & $0.58(0.50)$ \\
\hline $\mathrm{K}_{2} \mathrm{O}$ & $0.07(0.03)$ & $0.04(0.03)$ & $0.04(0.02)$ & $0.05(0.03)$ & $0.42(0.21)$ & $0.49(0.26)$ & $1.64(0.89)$ & $1.68(0.84)$ & $1.61(0.73)$ & $1.49(0.70)$ & $1.35(0.58)$ & $1.35(0.59)$ \\
\hline $\mathrm{P}_{2} \mathrm{O}_{5}$ & 0.10 & 0.13 & 0.07 & 0.10 & 0.52 & 0.50 & 2.49 & 2.88 & 3.02 & 3.81 & 4.07 & 3.51 \\
\hline \multicolumn{13}{|c|}{ Trace elements (ppm) } \\
\hline B & $(8.0)$ & (3.5) & $(0.8)$ & (3.5) & (15.6) & (10.7) & $(74.3)$ & (110) & (158) & (154) & (183) & (176) \\
\hline Ba & $1560(1430)$ & $1220(1050)$ & $1420(1130)$ & 1410 (1390) & $2760(1830)$ & $2490(2490)$ & $2230(1590)$ & $2490(2250)$ & $4060(3430)$ & $5390(2560)$ & $2400(2180)$ & $3120(2750)$ \\
\hline $\mathrm{Ce}$ & 1.5 & 1.7 & 1.7 & 2.2 & 12.8 & 12.3 & 35.4 & 39.9 & 38.5 & 33.0 & 36.9 & 38.9 \\
\hline Co & $6.5(6.0)$ & $16.1(15.8)$ & $13.7(12.2)$ & $7.0(6.0)$ & $19.0(14.0)$ & $20.4(16.7)$ & $45.2(33.5)$ & $64.9(38.8)$ & $81.1(52.1)$ & $75.4(42.3)$ & $88.8(45.0)$ & $85.5(41.4)$ \\
\hline $\mathrm{Cr}$ & 4.8 & 11.1 & 11.0 & 12.4 & 19.0 & 12.1 & 30.3 & 26.4 & 36.9 & 40.9 & 51.4 & 53.0 \\
\hline $\mathrm{Cu}$ & $49.5(49.5)$ & $55.6(53.5)$ & $31.1(25.6)$ & $35.6(33.6)$ & 149 (14I) & 187 (153) & $588(518)$ & $882(739)$ & $1150(1070)$ & $1090(963)$ & $1390(1190)$ & $1290(1120)$ \\
\hline La & 5.3 & 5.9 & 6.4 & 8.2 & 37.5 & 35.4 & 81.9 & 101 & 98.0 & 86.9 & 98.3 & 128 \\
\hline $\mathrm{Li}$ & $3.6(3.6)$ & $7.3(6.6)$ & $5.6(4.2)$ & $5.6(5.5)$ & $23.4(19.9)$ & $18.2(14.7)$ & $42.3(39.5)$ & $52.3(36.2)$ & $27.7(20.2)$ & $27.2(19.1)$ & $20.1(12.0)$ & $21.5(12.5)$ \\
\hline $\mathrm{Ni}$ & $10.3(9.3)$ & $32.7(32.7)$ & $19.8(19.8)$ & $16.4(16.3)$ & $57.1(52.0)$ & $88.9(78.5)$ & $316(290)$ & $784(570)$ & 713 (573) & 718 (575) & $748(656)$ & $835(735)$ \\
\hline $\mathbf{S c}$ & $1.1(1.0)$ & $1.6(1.4)$ & $1.7(1.3)$ & $2.1(1.9)$ & $7.6(6.2)$ & $8.0(5.8)$ & $19.5(14.9)$ & $21.6(15.6)$ & $17.5(13.7)$ & $14.2(10.5)$ & $14.1(10.0)$ & $14.5(9.9)$ \\
\hline $\mathrm{Sr}$ & 1010 & 1170 & 1240 & 1330 & 1740 & 1690 & 999 & 632 & 715 & 745 & 796 & 754 \\
\hline $\mathrm{Ti}$ & $81.9(66.4)$ & $127(84.4)$ & $104(66.4)$ & $112(74.4)$ & $510(152)$ & $529(142)$ & $1960(369)$ & $3040(526)$ & $2210(429)$ & $1400(242)$ & $1170(123)$ & $1180(98.4)$ \\
\hline $\mathrm{v}$ & $0.9(0.1)$ & $3.5(1.1)$ & $2.3(0.5)$ & $2.9(0.7)$ & $13.6(7.8)$ & $19.4(11.2)$ & $93.0(55.7)$ & 203 (125) & $427(221)$ & 413 (188) & $560(202)$ & 566 (184) \\
\hline Y & 10.4 & 12.4 & 11.1 & 15.6 & 69.1 & 60.3 & 154 & 164 & 151 & 133 & 149 & 171 \\
\hline $\mathrm{Zn}$ & $14.1(7.7)$ & $22.8(20.0)$ & $15.4(10.2)$ & $17.9(13.9)$ & $70.1(58.7)$ & $83.1(64.9)$ & 309 (268) & $490(431)$ & 574 (531) & 606 (575) & $685(603)$ & $685(607)$ \\
\hline
\end{tabular}

\begin{tabular}{|c|c|c|c|c|c|c|c|c|c|c|c|c|}
\hline & $\begin{array}{c}42-3 \\
75-76 \mathrm{~cm}\end{array}$ & $\begin{array}{l}42-3 \\
100-101 \mathrm{~cm}\end{array}$ & $\begin{array}{c}42-3 \\
122-123 \mathrm{~cm}\end{array}$ & $\begin{array}{c}42-3 \\
145-146 \mathrm{~cm}\end{array}$ & $\begin{array}{c}42-4 \\
25-26 \mathrm{~cm}\end{array}$ & $\begin{array}{c}42-4 \\
48-50 \mathrm{~cm}\end{array}$ & $\begin{array}{c}42-4 \\
75-76 \mathrm{~cm}\end{array}$ & $\begin{array}{c}42-4 \\
100-101 \mathrm{~cm}\end{array}$ & $\begin{array}{c}42-4 \\
125-126 \mathrm{~cm}\end{array}$ & $\begin{array}{c}42-4 \\
144-145 \mathrm{~cm}\end{array}$ & $\begin{array}{c}42-5 \\
26-27 \mathrm{~cm}\end{array}$ & $\begin{array}{c}43-1, \\
\text { (Piece } 1,3-4 \mathrm{~cm} \text { ) }\end{array}$ \\
\hline \multicolumn{13}{|c|}{ Major elements $(\%)$} \\
\hline $\mathrm{SiO}_{2}$ & 27.50 & 28.20 & 35.60 & 34.70 & 32.60 & 20.20 & 29.20 & 14.90 & 7.96 & 7.32 & 8.80 & 5.17 \\
\hline $\mathrm{Al}_{2} \mathrm{O}_{3}$ & $3.52(1.21)$ & $2.45(0.94)$ & $2.29(1.03)$ & $1.93(0.90)$ & $2.82(1.62)$ & $1.61(0.91)$ & $3.89(1.67)$ & $2.00(1.06)$ & $1.14(0.85)$ & $0.82(0.55)$ & $2.06(1.29)$ & $1.29(0.81)$ \\
\hline $\mathrm{Fe}_{2} \mathrm{O}_{3}$ & $28.10(21.50)$ & $24.30(13.50)$ & $24.00(14.80)$ & $23.60(15.10)$ & $16.70(9.83)$ & $10.70(6.48)$ & $12.00(5.09)$ & $5.56(2.91)$ & $2.89(2.28)$ & $3.21(2.36)$ & $2.19(1.56)$ & $1.19(0.74)$ \\
\hline $\mathrm{MnO}$ & $7.65(3.52)$ & $6.41(1.44)$ & $5.78(2.50)$ & $5.66(2.91)$ & $3.95(2.42)$ & $2.96(1.42)$ & 2.01 (1.04) & $0.86(0.51)$ & $0.40(0.39)$ & $0.69(0.38)$ & $0.12(0.05)$ & $0.13(0.08)$ \\
\hline $\mathrm{MgO}$ & $3.53(2.56)$ & $3.82(2.60)$ & $5.01(3.37)$ & $5.02(3.51)$ & $4.27(2.90)$ & 2.67 (1.87) & $3.89(2.11)$ & $1.87(1.18)$ & $0.95(0.86)$ & $0.89(0.78)$ & $1.44(1.19)$ & $1.22(1.03)$ \\
\hline $\mathrm{CaO}$ & 5.90 & 6.71 & 3.62 & 3.04 & 13.40 & 29.00 & 18.90 & 38.20 & 47.60 & 48.20 & 47.00 & 52.40 \\
\hline $\mathrm{Na}_{2} \mathrm{O}$ & $0.67(0.54)$ & $0.64(0.61)$ & $0.85(0.75)$ & $0.71(0.68)$ & $0.78(0.78)$ & $0.30(0.29)$ & $0.62(0.62)$ & $0.29(0.28)$ & $0.14(0.13)$ & $0.08(0.08)$ & $0.20(0.20)$ & $0.13(0.12)$ \\
\hline $\mathrm{K}_{2} \mathrm{O}$ & $1.25(0.58)$ & $1.10(0.54)$ & $1.20(0.65)$ & $1.04(0.63)$ & $1.21(0.72)$ & $0.73(0.47)$ & $1.04(0.62)$ & $0.58(0.36)$ & $0.37(0.30)$ & $0.32(0.23)$ & $0.34(0.27)$ & $0.23(0.19)$ \\
\hline $\mathrm{P}_{2} \mathrm{O}_{5}$ & 3.13 & 3.55 & 1.92 & 1.55 & 1.11 & 0.66 & 0.48 & 0.35 & 0.21 & 0.27 & 0.36 & 0.21 \\
\hline \multicolumn{13}{|c|}{ Trace elements (ppm) } \\
\hline B & (167) & (110) & (105) & (105) & $(65.4)$ & (38.9) & $(37.4)$ & (17.8) & $(17.8)$ & (15.6) & (20.5) & (2.1) \\
\hline $\mathrm{Ba}$ & $3320(2650)$ & $5150(2790)$ & $6210(5080)$ & $6920(6140)$ & $5220(3600)$ & $6180(4780)$ & $4370(4240)$ & $2080(1760)$ & $55.0(55.0)$ & $64.0(57.0)$ & $9.2(<5.0)$ & $20.0(<5.0)$ \\
\hline $\mathrm{Ce}$ & 31.8 & 24.9 & 21.6 & nd & 14.0 & 9.3 & 12.9 & 4.8 & 3.0 & 2.0 & 2.3 & 1.4 \\
\hline Co & $80.9(52.1)$ & $68.7(31.7)$ & $63.9(36.1)$ & $63.9(41.4)$ & $51.9(34.4)$ & $38.1(25.5)$ & $43.4(22.8)$ & $23.0(15.8)$ & $14.4(13.1)$ & $14.0(11.3)$ & $14.1(10.5)$ & $15.6(13.1)$ \\
\hline $\mathrm{Cr}$ & 50.6 & 41.7 & 36.3 & 30.6 & 33.8 & 27.9 & 21.4 & 18.8 & 14.0 & 14.8 & 21.2 & 19.5 \\
\hline $\mathrm{Cu}$ & $1180(1020)$ & $925(678)$ & $860(642)$ & 851 (638) & $615(427)$ & $368(272)$ & $394(215)$ & $212(126)$ & $73.4(61.8)$ & $104(85.2)$ & $71.3(53.2)$ & $31.3(25,7)$ \\
\hline La & 101 & 87.3 & 70.3 & nd & 40.0 & 30.0 & 22.7 & 13.8 & 7.6 & 6.9 & 3.7 & 4.1 \\
\hline $\mathrm{Li}$ & 24.3 (15.5) & $27.8(17.9)$ & $39.9(15.4)$ & $36.8(26.0)$ & $41.3(30.5)$ & $26.3(18.2)$ & $63.2(33.5)$ & $29.2(17.5)$ & $11.9(9.7)$ & $7.4(5.3)$ & $21.2(13.7)$ & $8.8(6.8)$ \\
\hline $\mathrm{Ni}$ & $812(714)$ & 614 (537) & $478(427)$ & 459 (398) & $261(218)$ & $162(131)$ & 154 (134) & 119 (105) & $49.0(47.9)$ & $158(124)$ & $98.8(79.3)$ & $80.7(69.2)$ \\
\hline Sc & $13.4(8.8)$ & $8.9(5.0)$ & $8.6(4.0)$ & $6.6(3.5)$ & $7.9(4.7)$ & $5.4(3.2)$ & $9.4(4.0)$ & $5.6(3.4)$ & $3.2(2.9)$ & $1.9(1.6)$ & $5.8(4.7)$ & $2.9(1.9)$ \\
\hline St & 770 & 690 & 583 & 477 & 767 & 1120 & 702 & 1020 & 796 & 807 & 436 & 222 \\
\hline $\mathrm{Ti}$ & $1100(146)$ & $824(54.4)$ & $825(55.4)$ & $670(48.4)$ & $1350(192)$ & $890(169)$ & $3240(129)$ & $1240(128)$ & $874(282)$ & $465(210)$ & 1360 (171) & 611 (195) \\
\hline v & $502(239)$ & 364 (132) & 278 (125) & 256 (124) & $12968.3)$ & $92.1(41.9)$ & $70.5(35.0)$ & $33.1(18.5)$ & $16.7(15.0)$ & $26.5(17.8)$ & $5.4(3.4)$ & $11.2(4.1)$ \\
\hline $\mathrm{Y}$ & 133 & 116 & 90.2 & nd & 57.0 & 42.9 & 33.0 & 21.4 & 12.9 & 9.9 & 10.8 & 20.1 \\
\hline $\mathrm{Zn}$ & $702(616)$ & $612(461)$ & $633(468)$ & 593 (451) & 431 (309) & $270(190)$ & $336(195)$ & $142(93.5)$ & $66.4(66.4)$ & $76.0(58.7)$ & $67.0(45.7)$ & $33.4(21.4)$ \\
\hline
\end{tabular}

Note: Total $\mathrm{Fe}$ is expressed as $\mathrm{Fe}_{2} \mathrm{O}_{3}$. Values in parentheses are the $\mathrm{HCl}$-soluble portion of the sample. nd $=$ not determined. 
APPENDIX B

Major and Trace Element Composition of Basal Sediments from Hole 574C

\begin{tabular}{|c|c|c|c|c|c|c|c|c|c|c|c|c|c|c|c|}
\hline & $\begin{array}{l}32-2 . \\
54-55 \mathrm{~cm}\end{array}$ & $\begin{array}{l}33-3 . \\
56-57 \mathrm{~cm}\end{array}$ & $\begin{array}{c}33-4 \\
73-74 \mathrm{~cm}\end{array}$ & $\begin{array}{r}33-4 \\
102-103 \mathrm{~cm}\end{array}$ & $\begin{array}{c}33-5, \\
2-3 \mathrm{~cm}\end{array}$ & $\begin{array}{c}33.5 \\
34-35 \mathrm{~cm}\end{array}$ & $\begin{array}{c}33-5, \\
61-62 \mathrm{~cm}\end{array}$ & $\begin{array}{c}33-5 . \\
74-75 \mathrm{~cm}\end{array}$ & $\begin{array}{l}33-5 \\
100-102 \mathrm{~cm}\end{array}$ & $\begin{array}{l}33-5, \\
120-122 \mathrm{~cm}\end{array}$ & $\begin{array}{c}33-5, \\
148-149 \mathrm{~cm}\end{array}$ & $\begin{array}{c}34-1, \\
47-48 \mathrm{~cm}\end{array}$ & $\begin{array}{l}34-1, \\
75-76 \mathrm{~cm}\end{array}$ & $\begin{array}{l}34-1, \\
97-98 \mathrm{~cm}\end{array}$ & $\begin{array}{l}34-1, \\
121-122 \mathrm{~cm}\end{array}$ \\
\hline \multicolumn{16}{|c|}{ Major elements (\%) } \\
\hline & & & & & & & & & & & 13.20 & & & & \\
\hline 散 $2_{2} \mathrm{O}_{3}$ & $0.21(0.1$ & & $0.57(0.38)$ & $0.75(0.49)$ & $0.89(0.56)$ & $1.89(1.18)$ & $1.41(0.91)$ & $1.20(0.77)$ & $1.38(0.87)$ & $1.25(0.74)$ & $0.93(0.57)$ & $0.81(0.55)$ & $0.63(0.45)$ & $0.54(0.37)$ & $0.78(0.55)$ \\
\hline $\mathrm{Fe}_{2} \mathrm{O}_{3}$ & $0.07(0.04)$ & $0.51(0.40)$ & $0.63(0.56)$ & $0.72(0.64)$ & $1.02(0.90)$ & $2.20(1.99)$ & $2.12(1.99)$ & $1.80(1.72)$ & $1.95(1.83)$ & $1.88(1.71)$ & $1.46(1.29)$ & $1.52(1.41)$ & 1.18 (1.14) & $0.91(0.83)$ & $1.53(1.44)$ \\
\hline $\mathrm{MnO}$ & $0.01(0.01)$ & $0.01(0.01)$ & $0.01(0.01)$ & $0.04(0.04)$ & $0.12(0.12)$ & $0.30(0.30)$ & $0.40(0.40)$ & $0.37(0.36)$ & $0.23(0.23)$ & $0.22(0.22)$ & $0.16(0.16)$ & $0.15(0.15)$ & $0.14(0.14)$ & $0.11(0.10)$ & $0.18(0.18)$ \\
\hline $\mathrm{MgO}$ & $0.19(0.19)$ & $0.41(0.41)$ & $0.54(0.54)$ & $0.52(0.52)$ & $0.67(0.67)$ & $1.20(1.20)$ & $1.17(1.17)$ & $1.04(1.04)$ & $1.12(1.12)$ & $1.08(1.08)$ & $0.88(0.88)$ & $0.91(0.91)$ & $0.77(0.77)$ & $0.65(0.65)$ & $0.98(0.98)$ \\
\hline $\mathrm{CaO}$ & 46.70 & 48.70 & 47.50 & 45.90 & 44.00 & 36.10 & 39.50 & 40.60 & 38.80 & 40.60 & 42.90 & 41.40 & & & \\
\hline $\begin{array}{l}\mathrm{Na}_{2} \mathrm{O} \\
\mathrm{K}_{2} \mathrm{O}\end{array}$ & $0.11(0.06)$ & $0.11(0.09)$ & $0.09(0.06)$ & $0.11(0.07)$ & $0.12(0.10)$ & $0.35(0.26)$ & $0.20(0.14)$ & $0.16(0.10)$ & $0.18(0.12)$ & $0.17(0$ & $0.13(0$ & $0.13(0.08)$ & $0.13(0.07)$ & $0.13(0$ & 0.1210 \\
\hline $\begin{array}{ll}\mathrm{K}_{2} \mathrm{O}_{2} \\
\mathrm{P}_{2} \mathrm{O}_{5}\end{array}$ & $\begin{array}{l}0.4(0.04) \\
0.05\end{array}$ & $\begin{array}{l}0.15(0.11) \\
0.13\end{array}$ & $0.10(0.08)$ & $0.14(0.10)$ & $0.16(0.12)$ & $0.36(0.26)$ & $0.26(0.18)$ & $0.21(0.1$ & 0.2410 & & 0.16 & & 0.1210 & & \\
\hline \multirow{2}{*}{\multicolumn{16}{|c|}{ Trace elements (ppm) }} \\
\hline & & & & & & & & & & & & & & & \\
\hline B & (0.8) & $(0.08)$ & (3.5) & (3.5) & (3.5) & (15. & (15. & & & (10. & 18.0 & & & & \\
\hline $\mathrm{Ba}$ & 1810 (181 & $4650(4650)$ & $3980(3980)$ & $5720(5720)$ & 5510 (5510) & $2880(2880)$ & $3010(3010)$ & $3410(3410)$ & $3430(3430)$ & $3250(3250)$ & $5120(5120)$ & 5510 (5510) & $5050(5050)$ & $4540(4540)$ & $5230(5230)$ \\
\hline $\mathrm{Ce}$ & 0.9 & 4.0 & 3.0 & 6.1 & 5.3 & 11.7 & 9.8 & 8.1 & 9.5 & 8.0 & 6.7 & 5.8 & 4.4 & 3.5 & 5.4 \\
\hline Co & & & & & 6.74 & $10.7(8.0)$ & 9.7( & 8.90 & 8.1( & 22.00( & 7.31 & $8.3(5.4)$ & 6.1 & $4.1(2$ & $6.3 \mathrm{is}$ \\
\hline $\mathrm{Cr}$ & 5.9 & 6.9 & 6.8 & 14.2 & 17.6 & & 12.1 & 19.6 & & 11.3 & 7.8 & & & & \\
\hline $\mathrm{Cu}$ & $21.8(21.8)$ & $60.5(59.0)$ & $61.3(61.3)$ & $\begin{array}{l}73.3(71.9) \\
12.3\end{array}$ & 91.0 (88.6) & $164(153)$ & 166 (157) & $142(136)$ & $114(108)$ & $110(99.0)$ & $90.8(84.3)$ & $100(92.4)$ & $84.5(80.6)$ & $64.9(63.4)$ & \\
\hline${ }_{\mathrm{Li}}^{\mathrm{La}}$ & $\begin{array}{l}4.1 \\
3.4(2.9)\end{array}$ & $\begin{array}{l}11.8 \\
13.9(13.9)\end{array}$ & $\begin{array}{r}9.7 \\
20.9(20 \text {. }\end{array}$ & $\begin{array}{l}12.3 \\
18.40\end{array}$ & $\begin{array}{l}13.7 \\
23.4(20,7\end{array}$ & $\begin{array}{l}27.8 \\
42.5(36.8)\end{array}$ & $\begin{array}{l}25.2 \\
38.5135,1\end{array}$ & $\begin{array}{l}21.5 \\
340(32,13\end{array}$ & $\begin{array}{l}25.0 \\
37.0635,7\end{array}$ & $\begin{array}{l}21.7 \\
34.70\end{array}$ & $\begin{array}{l}19.0 \\
28.50\end{array}$ & 17.3 & 13.6 & & \\
\hline Ni & 5.8 & 13. & & $\begin{array}{r}18.440 \\
1540\end{array}$ & $\begin{array}{l}23.4 .42 \\
25112\end{array}$ & 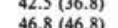 & (5), & $\begin{array}{l}34.0732 \\
50.750\end{array}$ & 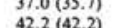 & 37.38 & 28.59 & 23.312 & 2048 & & \\
\hline Sc & 0. & $3.2(2.8)$ & 2.912 & $3.6(3$. & $4.3(3,7)$ & $\begin{array}{r}40.8(4) \\
8.47\end{array}$ & $5.9(5,2)$ & $5.0(4.5)$ & $5,3(4,7)$ & $4.7(4,0)$ & $\begin{array}{l}4.07(3,2) \\
3.7(2)\end{array}$ & $3.4(2.9)$ & $29(2.5)$ & $\begin{array}{l}19.8(19.8) \\
2.4(2.0)\end{array}$ & \\
\hline Sr & & 1850 & 1600 & 1600 & & & & & & & & & & & \\
\hline $\mathrm{Ti}$ & 68.746 & $167(87$ & $131(8$ & 1578 & $189(9)$ & & & & & & & & 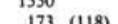 & & \\
\hline v & $1.8(0.5)$ & & ) & & 6.612 & & & & & & & & 6 & & $\begin{array}{l}206(129) \\
8.0(3.8)\end{array}$ \\
\hline$y$ & & & & & & & & & & & & & 19.0 & & 3 \\
\hline $\mathrm{z} n$ & $12.3(6.5)$ & $24.7(22.5$ & $(24,720.0)$ & $26.6(23.9)$ & 37.736 .3 & 7 & 70.169 .8 & $60.7(53,6)$ & $58.9655 .0)$ & $54.5150,0$ & $44.0(38.8)$ & $47.7(42.5$ & $42.8(36,3)$ & 34.726 .3 & $53.4(41,3)$ \\
\hline
\end{tabular}

\begin{tabular}{|c|c|c|c|c|c|c|c|c|c|c|c|c|c|c|c|}
\hline & $\begin{array}{l}34-2, \\
3-4 \mathrm{~cm}\end{array}$ & $\begin{array}{c}34-2, \\
24-25 \mathrm{~cm}\end{array}$ & $\begin{array}{c}34-2, \\
50-51 \mathrm{~cm}\end{array}$ & $\begin{array}{c}34-2, \\
74-75 \mathrm{~cm}\end{array}$ & $\begin{array}{c}34-2, \\
100-101 \mathrm{~cm}\end{array}$ & $\begin{array}{c}34-2, \\
121-122 \mathrm{~cm}\end{array}$ & $\begin{array}{l}35-1, \\
9-10 \mathrm{~cm}\end{array}$ & $\begin{array}{c}35-1 \\
100-101 \mathrm{~cm}\end{array}$ & $\begin{array}{c}35-1, \\
124-125 \mathrm{~cm}\end{array}$ & $\begin{array}{c}35-2, \\
2-3 \mathrm{~cm}\end{array}$ & $\begin{array}{c}35-2, \\
26-27 \mathrm{~cm}\end{array}$ & $\begin{array}{c}35.2 \\
49-50 \mathrm{~cm}\end{array}$ & $\begin{array}{c}35-2 . \\
75-76 \mathrm{~cm}\end{array}$ & $\begin{array}{c}35-2, \\
97-98 \mathrm{~cm}\end{array}$ & $\begin{array}{l}35, \mathrm{cc} \\
0-2 \mathrm{~cm}\end{array}$ \\
\hline \multicolumn{16}{|c|}{ Major elements $(\%)$} \\
\hline $\mathrm{SiO}_{2}$ & 12.80 & 14.60 & 19.10 & 23.20 & 26.70 & 27.80 & 9.91 & 12.00 & 8.98 & 13.50 & 7.70 & 10.10 & 15,90 & 12.00 & 17.00 \\
\hline $\mathrm{Al}_{2} \mathrm{O}_{3}$ & $0.52(0.34)$ & $0.69(0.46)$ & $0.88(0.59)$ & $0.99(0.59)$ & $1.30(0.91)$ & $1.38(0.96)$ & $1.75(1.11)$ & $1.87(1.01)$ & $1.34(0.90)$ & $2.56(1.42)$ & $1.28(0.81)$ & $2.01(1.10)$ & $3.33(1.73)$ & $2.48(1.40)$ & $3.44(1.29)$ \\
\hline $\mathrm{Fe}_{2} \mathrm{O}_{3}$ & $0.87(0.7$ & 1.29 (1.1 & $1.43(1.28)$ & & & & & & $2.87(2.18)$ & $3.85(2.76)$ & $1.90(1.54)$ & $2.40(1.76)$ & $3.80(2.21)$ & $2.54(1.74)$ & $4.02(1.73)$ \\
\hline $\begin{array}{ll}\mathrm{MnO} \\
\mathrm{MoO}\end{array}$ & $\begin{array}{l}0.11(0.11) \\
0.67(0.67)\end{array}$ & $0.16(0.16)$ & $0.15(0.15)$ & $0.30(0.30)$ & $0.29(0.28)$ & $0.33(0.32)$ & $0.73(0.41)$ & $0.45(0.39)$ & $0.44(0.42)$ & $0.40(0.38)$ & $0.20(0.16)$ & $0.24(0.20)$ & $0.22(0.14)$ & $0.19(0.14)$ & $0.38(0.14)$ \\
\hline $\begin{array}{l}\mathrm{MgO} \\
\mathrm{CaO}\end{array}$ & $\begin{array}{l}0.67(0.67) \\
43.80\end{array}$ & $\begin{array}{l}0.88(0.88) \\
41.80\end{array}$ & $\begin{array}{l}1.01 .90 \\
38.01\end{array}$ & $\begin{array}{l}1.957(1.57) \\
31.90\end{array}$ & 30.50 & $\begin{array}{l}2.266 \\
33.00\end{array}$ & $\begin{array}{l}1.34(1.17) \\
43.10\end{array}$ & $\begin{array}{l}1.52(1.16) \\
41.50\end{array}$ & $\begin{array}{l}1.22(1.05) \\
44.90\end{array}$ & $\begin{array}{l}1.78(1.37) \\
38.90\end{array}$ & $\begin{array}{l}1.05 .0 .8 \\
48.10\end{array}$ & $\begin{array}{c}1.36 \text { (1. } \\
44.40\end{array}$ & $\begin{array}{l}2.23(1.52) \text {. } \\
37.40\end{array}$ & $\begin{array}{l}1.57(1.19) \\
41.20\end{array}$ & 34.40 \\
\hline $\mathrm{Na}_{2} \mathrm{O}$ & $0.10(0.05)$ & $0.11(0.07)$ & $0.13(0.06)$ & $0.18(0.08)$ & $0.25(0.15)$ & $0.26(0.17)$ & $0.19(0.19)$ & $0.20(0.19)$ & $0.15(0.15)$ & $0.31(0.29)$ & $0.14(0.13)$ & $0.22(0.18)$ & $0.44(0.42)$ & $0.27(0.27)$ & $0.42(0.42)$ \\
\hline $\mathrm{K}_{2} \mathrm{O}$ & $0.10(0.06)$ & $0.13(0.08)$ & $0.14(0.10)$ & $0.16(0.10)$ & $0.23(0.16)$ & $0.25(0.18)$ & $0.46(0.30)$ & $0.48(0.31)$ & $0.36(0.26)$ & $0.58(0.41)$ & $0.30(0.20)$ & $0.36(0.27)$ & $0.58(0.43)$ & $0.46(0.35)$ & $0.64(0.4$ \\
\hline & 0.14 & 0.16 & 0.17 & 0.18 & 0.25 & 0.28 & & 0.33 & 0.25 & 0.36 & & & & & \\
\hline
\end{tabular}

Trace elements (ppm)

\begin{tabular}{|c|c|c|c|c|c|c|c|c|c|c|c|c|c|c|c|}
\hline $\begin{array}{l}\mathrm{B} \\
\mathrm{B}\end{array}$ & $\begin{aligned} & (0.8) \\
4400 & (4480)\end{aligned}$ & $\begin{array}{c}(3.5) \\
5110(5110)\end{array}$ & $\begin{array}{c}(3.5) \\
5420(5420)\end{array}$ & $\begin{array}{c}(3.5) \\
3900(3900)\end{array}$ & $\begin{array}{r}(12.9) \\
3460(3460) \\
(3)\end{array}$ & $\begin{array}{r}(20.5) \\
3260 \\
(3260)\end{array}$ & $2710 \begin{array}{c}(15.6) \\
(2710)\end{array}$ & $\begin{array}{r}(14.2) \\
3230 \\
(3230)\end{array}$ & $\begin{array}{r}(15.6) \\
3740 \\
(3740)\end{array}$ & $\begin{array}{r}(20.5) \\
2750 \\
(2750)\end{array}$ & $\begin{aligned} &(6.2)(6150 \\
&(4150)\end{aligned}$ & $\begin{array}{r}(10.6) \\
4070(4070)\end{array}$ & $\begin{array}{r}(15.6) \\
3610 \\
(3610)\end{array}$ & $3360\left(\begin{array}{r}(10.7) \\
(3360)\end{array}\right.$ & $\begin{array}{r}(10.7) \\
4210(4210)\end{array}$ \\
\hline & & & & & & & & & & & & & & & \\
\hline co & $4.5(3.4)$ & $6.5(5.2)$ & $6.7(5.4)$ & $6.7(5.7)$ & $7.7(6.5)$ & $10.7(8.2)$ & $16.2(14.0)$ & $20.4(14.0)$ & $19.0(15.8)$ & $26.6(22.8)$ & $14.6(13.1)$ & $18.0(14.9)$ & $26.5(16$ & 17.51 & 26.01 \\
\hline $\mathrm{Cr}_{\mathrm{r}}$ & 6.5 & 8.7 & 7.9 & 5.9 & 19.0 & 21.2 & 20.0 & 16.0 & 13.2 & 15.1 & 8.7 & 9.5 & 14.0 & & 13.0 \\
\hline Cu & $69.7(62.7)$ & $97.0(87.8)$ & $104(96.4)$ & $154(125)$ & 166 (157) & 189 (175) & $306(256)$ & 168( & 1480 & 178 (127) & $99.8(73.4)$ & 1108 & 1194 & 87.21 & $126 \mathrm{C}$ \\
\hline L & 10.9 & 13.4 & 14.2 & 16.6 & 19.5 & 20.8 & 23.3 & 22.3 & 18.8 & $\begin{array}{l}27.0 \\
4061329\end{array}$ & $\begin{array}{l}13.7 \\
23.481\end{array}$ & 12.3 & $\begin{array}{l}13.1 \\
664433.6\end{array}$ & 11.2 & $\begin{array}{l}14.9 \\
48.915\end{array}$ \\
\hline $\begin{array}{l}\mathrm{Li} \\
\mathrm{Ni}\end{array}$ & 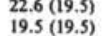 & $\begin{array}{r}30.1(25.8) \\
19.9(19.9)\end{array}$ & $\begin{array}{l}36.0(31.3) \\
22.5(22.5)\end{array}$ & 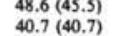 & $\begin{array}{r}64.5 \\
35.4(35.4)\end{array}$ & $\begin{array}{l}82.7 \\
41.3(41.3)\end{array}$ & $\begin{array}{r}32.6(30.0) \\
135(97.4)\end{array}$ & $\begin{array}{r}36.8(26.8) \\
45.3(39.2)\end{array}$ & $\begin{array}{r}25.4(21.6 .6 \\
59.7(55.3\end{array}$ & $\begin{array}{l}40.6(3.2 .9) \\
54.1(49.2)\end{array}$ & 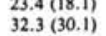 & $\begin{array}{l}41.0(23.1) \\
41.4(36.4)\end{array}$ & $\begin{array}{r}56.4(33.6) 6 \\
38.9(32.6)\end{array}$ & $\begin{array}{r}36.6(25.1 .5) \\
35.5(31.5)\end{array}$ & $\begin{array}{l}48.5(2.57 \\
74.5\end{array}$ \\
\hline s & $2.4(2.0)$ & $3.3(2.6)$ & $4.2(3.4)$ & $4.6(3.3)$ & $6.0(5.1)$ & $6.7(5.8)$ & $6.4(4.8)$ & $7.2(4.2)$ & $5.4(4.0)$ & 8.61 & 4.91 & $6.5(4.7)$ & $9.8(5.9)$ & $7.3(4.9)$ & $10.4(4.7)$ \\
\hline & & 1540 & 1430 & & 1260 & 1360 & 1560 & 1510 & 1530 & 1440 & 1470 & 1370 & 1210 & 1260 & 1110 \\
\hline & $161(100)$ & 218 (135) & $270(167)$ & $361(129)$ & $315(214)$ & $433(265)$ & 820 (195) & 975 (150) & $745(227)$ & $1570(253)$ & 8281 & 1170 (231) & 27100 & 1720 (174) & $2520(90.4)$ \\
\hline & $\begin{array}{l}47.7(2.0) \\
17.5\end{array}$ & $\begin{array}{l}7.07^{7(3.4)} \\
21.0\end{array}$ & $\begin{array}{l}8.4(4.3) \\
23.0\end{array}$ & $\begin{array}{l}9.2(4.4) \\
25.0\end{array}$ & $\begin{array}{l}12.2(7.2) \\
30.8\end{array}$ & $\begin{array}{l}13.2 \\
33.6\end{array}$ & $\begin{array}{l}29.1(20.4) \\
32.3\end{array}$ & $\begin{array}{r}29.3(17,1) \\
33.4\end{array}$ & $\begin{array}{l}26.9(20.5) \\
26.4\end{array}$ & $\begin{array}{l}31.2(21.7) \\
40.7\end{array}$ & $\begin{array}{l}14.31 \\
20.7\end{array}$ & ${ }_{20.5}^{17.2(11.0)}$ & $\begin{array}{l}18.64 \\
22.5\end{array}$ & $\begin{array}{l}13.4(7.6) \\
20.3\end{array}$ & $\begin{array}{l}25.2(12.0) \\
26.8\end{array}$ \\
\hline & $34.0(23.9)$ & $48.3(32.6)$ & $30.8(41.3)$ & $68.2(53.7)$ & $86.8(74.9)$ & $98.0(87.3)$ & $91.0(67.4)$ & $90.5(52.5)$ & $71.9(52.5)$ & $88.1(66.2)$ & $52.6(36.3)$ & $64.5(41.3)$ & nd (42.5) & $58.9(41.0)$ & $84.4(37.6)$ \\
\hline
\end{tabular}


APPENDIX C

Rare Earth Element Composition (ppm) of Basal Sediments from Holes 573B and 574C

\begin{tabular}{|c|c|c|c|c|c|c|c|c|c|c|c|c|}
\hline & $\mathrm{La}$ & $\mathrm{Ce}$ & Pr & $\mathrm{Nd}$ & Sm & Eu & Gd & Dy & Ho & Er & $\mathrm{Yb}$ & Lu \\
\hline \multicolumn{13}{|l|}{ Hole 573B } \\
\hline $40-1,104-106 \mathrm{~cm}$ & 5.33 & 1.50 & 1.38 & 4.98 & 1.25 & 0.37 & 1.23 & 1.27 & 0.31 & 0.91 & 0.82 & 0.19 \\
\hline $42-1,45-46 \mathrm{~cm}$ & 5.92 & 1.67 & 1.65 & 5.88 & 1.41 & 0.41 & 1.56 & 1.51 & 0.37 & 0.95 & 0.97 & 0.20 \\
\hline $42-1,125-126 \mathrm{~cm}$ & 6.41 & 1.74 & 1.21 & 5.22 & 1.16 & 0.31 & 1.35 & 1.33 & 0.31 & 0.90 & 0.92 & 0.18 \\
\hline $42-1,149-150 \mathrm{~cm}$ & 8.19 & 2.16 & 1.75 & 7.08 & 1.65 & 0.47 & 1.67 & 1.79 & 0.44 & 1.18 & 1.28 & 0.26 \\
\hline $42-2,25-26 \mathrm{~cm}$ & 37.50 & 12.80 & 7.87 & 34.30 & 7.26 & 2.04 & 8.64 & 8.35 & 1.92 & 5.34 & 5.44 & 0.88 \\
\hline $42-2,50-51 \mathrm{~cm}$ & 35.40 & 12.30 & 7.30 & 33.60 & 6.83 & 1.90 & 8.15 & 7.91 & 1.79 & 5.03 & 4.78 & 0.77 \\
\hline $42-2,76-77 \mathrm{~cm}$ & 81.90 & 35.40 & 18.20 & 83.20 & 17.00 & 4.93 & 20.60 & 19.30 & 4.37 & 12.10 & 12.50 & 2.00 \\
\hline $42-2,99-100 \mathrm{~cm}$ & 101.00 & 39.90 & 19.80 & 89.80 & 18.40 & 5.30 & 22.40 & 21.80 & 4.97 & 13.60 & 13.80 & 2.24 \\
\hline $42-2,125-126 \mathrm{~cm}$ & 98.00 & 38.50 & 21.00 & 92.60 & 18.70 & 5.56 & 21.80 & 20.60 & 4.59 & 12.50 & 12.90 & 2.00 \\
\hline $42-2,149-150 \mathrm{~cm}$ & 86.90 & 33.00 & 19.30 & 84.50 & 16.80 & 5.01 & 19.60 & 18.70 & 4.15 & 11.40 & 11.60 & 1.77 \\
\hline $42-3,25-26 \mathrm{~cm}$ & 98.30 & 36.90 & 22.30 & 98.50 & 19.40 & 5.80 & 22.50 & 21.30 & 4.69 & 12.70 & 12.70 & 1.91 \\
\hline $42-3,48-49 \mathrm{~cm}$ & 128.00 & 38.90 & 24.00 & 110.00 & 21.40 & 6.09 & 25.20 & 24.70 & 5.51 & 14.90 & 14.40 & 2.21 \\
\hline $42-3,75-76 \mathrm{~cm}$ & 101.00 & 31.80 & 19.40 & 87.30 & 16.70 & 4.94 & 19.60 & 19.20 & 4.28 & 11.70 & 11.50 & 1.74 \\
\hline $42-3,100-101 \mathrm{~cm}$ & 87.30 & 24.90 & 15.70 & 71.90 & 13.80 & 3.99 & 16.70 & 16.60 & 3.73 & 10.10 & 9.79 & 1.54 \\
\hline $42-3,122-123 \mathrm{~cm}$ & 70.30 & 21.60 & 12.90 & 58.30 & 11.50 & 3.36 & 13.90 & 13.30 & 2.96 & 7.84 & 7.62 & 1.20 \\
\hline $42-4,25-26 \mathrm{~cm}$ & 40.00 & 14.00 & 7.94 & 34.70 & 6.94 & 2.15 & 8.19 & 8.04 & 1.82 & 4.93 & 5.07 & 0.80 \\
\hline $42-4,48-50 \mathrm{~cm}$ & 30.00 & 9.28 & 5.66 & 25.80 & 5.12 & 1.54 & 6.98 & 6.14 & 1.37 & 3.82 & 3.76 & 0.56 \\
\hline $42-4,75-76 \mathrm{~cm}$ & 22.70 & 12.90 & 4.98 & 22.40 & 4.58 & 1.46 & 5.64 & 5.29 & 1.16 & 3.18 & 3.07 & 0.47 \\
\hline $42-4,100-101 \mathrm{~cm}$ & 13.80 & 4.81 & 2.60 & 12.50 & 2.48 & 0.78 & 3.35 & 3.32 & 0.75 & 2.27 & 2.09 & 0.31 \\
\hline $42-4,125-126 \mathrm{~cm}$ & 7.60 & 2.99 & 1.56 & 7.30 & 1.50 & 0.47 & 2.93 & 2.07 & 0.45 & 1.42 & 1.26 & 0.18 \\
\hline $42-4,144-145 \mathrm{~cm}$ & 6.93 & 2.00 & 1.30 & 6.44 & 1.23 & 0.36 & 1.55 & 1.59 & 0.35 & 1.10 & 0.94 & 0.13 \\
\hline $42-5,26-27 \mathrm{~cm}$ & 3.71 & 2.33 & 0.64 & 3.62 & 0.89 & 0.34 & 1.65 & 1.35 & 0.31 & 0.80 & 0.99 & 0.15 \\
\hline 42-5, (Piece 1, 3-4 cm) & 4.08 & 1.38 & 0.66 & 3.43 & 0.95 & 0.36 & 1.80 & 1.83 & 0.47 & 1.41 & 1.68 & 0.28 \\
\hline \multicolumn{13}{|l|}{ Hole $574 \mathrm{C}$} \\
\hline $32-2,54-55 \mathrm{~cm}$ & 4.06 & 0.93 & 0.69 & 3.20 & 0.68 & 0.19 & 0.86 & 0.78 & 0.17 & 0.49 & 0.54 & 0.09 \\
\hline $33-3,56-57 \mathrm{~cm}$ & 11.80 & 3.97 & 2.24 & 10.50 & 2.25 & 0.63 & 2.66 & 2.36 & 0.52 & 1.44 & 1.44 & 0.25 \\
\hline $33-4,73-74 \mathrm{~cm}$ & 9.71 & 3.01 & 1.64 & 7.93 & 1.74 & 0.49 & 2.04 & 1.80 & 0.39 & 1.10 & 1.18 & 0.21 \\
\hline $33-4,102-103 \mathrm{~cm}$ & 12.30 & 6.05 & 2.15 & 9.93 & 2.18 & 0.61 & 2.57 & 2.29 & 0.51 & 1.38 & 1.46 & 0.27 \\
\hline $33-5,2-3 \mathrm{~cm}$ & 13.70 & 5.26 & 2.49 & 11.70 & 2.52 & 0.71 & 2.96 & 2.62 & 0.56 & 1.55 & 1.66 & 0.28 \\
\hline $33-5,34-35 \mathrm{~cm}$ & 27.80 & 11.70 & 5.52 & 25.00 & 5.34 & 1.49 & 6.24 & 5.42 & 1.17 & 3.15 & 3.18 & 0.53 \\
\hline $33-5,61-62 \mathrm{~cm}$ & 25.20 & 9.83 & 4.34 & 20.20 & 4.43 & 1.28 & 5.35 & 4.57 & 1.00 & 2.78 & 2.98 & 0.51 \\
\hline $33-5,74-75 \mathrm{~cm}$ & 21.50 & 8.11 & 4.01 & 18.50 & 4.02 & 1.14 & 4.76 & 4.05 & 0.87 & 2.37 & 2.40 & 0.42 \\
\hline $33-5,100-102 \mathrm{~cm}$ & 25.00 & 9.53 & 4.84 & 22.00 & 4.71 & 1.35 & 5.64 & 4.84 & 1.04 & 2.82 & 2.82 & 0.48 \\
\hline $3-5,120-122 \mathrm{~cm}$ & 21.70 & 8.00 & 4.14 & 19.00 & 4.02 & 1.15 & 4.80 & 4.10 & 0.89 & 2.38 & 2.36 & 0.40 \\
\hline $33-5,148-149 \mathrm{~cm}$ & 19.00 & 6.73 & 3.38 & 15.50 & 3.32 & 0.95 & 3.93 & 3.43 & 0.74 & 2.05 & 2.05 & 0.35 \\
\hline $34-1,47-48 \mathrm{~cm}$ & 17.30 & 5.75 & 3.08 & 14.30 & 3.04 & 0.88 & 3.69 & 3.12 & 0.68 & 1.84 & 1.86 & 0.32 \\
\hline $34-1,75-76 \mathrm{~cm}$ & 13.60 & 4.38 & 2.48 & 11.60 & 2.44 & 0.71 & 2.92 & 2.50 & 0.55 & 1.52 & 1.52 & 0.27 \\
\hline $34-1,97-98 \mathrm{~cm}$ & 10.70 & 3.50 & 1.88 & 8.77 & 1.87 & 0.53 & 2.24 & 2.01 & 0.44 & 1.24 & 1.32 & 0.23 \\
\hline $34-1,121-122 \mathrm{~cm}$ & 14.90 & 5.40 & 2.67 & 12.70 & 2.74 & 0.79 & 3.21 & 2.93 & 0.65 & 1.74 & 1.83 & 0.31 \\
\hline $34-2,3-4 \mathrm{~cm}$ & 10.90 & 3.52 & 1.84 & 9.13 & 1.96 & 0.56 & 2.35 & 2.11 & 0.48 & 1.31 & 1.37 & 0.23 \\
\hline $34-2,24-25 \mathrm{~cm}$ & 13.40 & 4.78 & 2.35 & 11.40 & 2.51 & 0.73 & 3.01 & 2.65 & 0.58 & 1.73 & 1.59 & 0.27 \\
\hline $34-2,50-51 \mathrm{~cm}$ & 14.20 & 5.20 & 2.73 & 12.80 & 2.78 & 0.80 & 3.12 & 2.91 & 0.65 & 1.87 & 1.79 & 0.29 \\
\hline $34-2,74-75 \mathrm{~cm}$ & 16.60 & 6.63 & 3.06 & 14.70 & 3.20 & 0.93 & 3.61 & 3.24 & 0.70 & 2.05 & 1.91 & 0.32 \\
\hline $34-2,100-101 \mathrm{~cm}$ & 19.50 & 6.95 & 3.74 & 17.40 & 3.75 & 1.06 & 4.26 & 3.97 & 0.86 & 2.50 & 2.43 & 0.40 \\
\hline $34-2,121-122 \mathrm{~cm}$ & 20.80 & 8.04 & 3.97 & 18.50 & 4.01 & 1.17 & 4.63 & 4.26 & 0.94 & 2.68 & 2.65 & 0.45 \\
\hline $35-1,9-10 \mathrm{~cm}$ & 23.30 & 7.52 & 4.64 & 21.60 & 4.53 & 1.32 & 5.63 & 4.71 & 1.02 & 2.90 & 2.78 & 0.42 \\
\hline $35-1,100-101 \mathrm{~cm}$ & 22.30 & 8.58 & 4.96 & 21.00 & 4.43 & 1.36 & 5.80 & 4.66 & 1.01 & 2.71 & 2.79 & 0.41 \\
\hline $35-1,124-125 \mathrm{~cm}$ & 18.80 & 5.60 & 3.53 & 16.90 & 3.54 & 1.02 & 4.54 & 3.82 & 0.83 & 2.37 & 2.22 & 0.35 \\
\hline $35-2,2-3 \mathrm{~cm}$ & 27.00 & 9.70 & 4.99 & 23.70 & 5.15 & 1.56 & 7.44 & 5.41 & 1.18 & 3.08 & 3.30 & 0.51 \\
\hline $35-2,26-27 \mathrm{~cm}$ & 13.70 & 3.96 & 2.50 & 12.50 & 2.63 & 0.77 & 3.28 & 2.94 & 0.64 & 1.86 & 1.77 & 0.28 \\
\hline $35-2,49-50 \mathrm{~cm}$ & 12.30 & 5.45 & 1.79 & 11.20 & 2.45 & 0.74 & 3.30 & 2.93 & 0.68 & 1.93 & 1.77 & 0.29 \\
\hline $35-2,75-76 \mathrm{~cm}$ & 13.10 & 6.16 & 2.50 & 12.60 & 2.88 & 0.91 & 3.80 & 3.31 & 0.72 & 2.07 & 1.96 & 0.30 \\
\hline $35-2,97-98 \mathrm{~cm}$ & 11.20 & 4.82 & 2.24 & 10.80 & 2.41 & 0.79 & 4.05 & 2.87 & 0.64 & 1.72 & 1.82 & 0.27 \\
\hline $35, \mathrm{CC}(0-2 \mathrm{~cm})$ & 14.90 & 6.66 & 3.05 & 15.10 & 3.37 & 1.05 & 4.69 & 4.14 & 0.90 & 2.57 & 2.41 & 0.37 \\
\hline
\end{tabular}

APPENDIX D

Major and Trace Element Composition of

Tholeiitic Basalts

573B-43-1

$574 C-36-1$

(Piece 2, 24-26 cm) (Piece 5, 34-39 cm)

Major elements (\%)

\begin{tabular}{lrr}
$\mathrm{SiO}_{2}$ & \multicolumn{1}{c}{41.20} & \multicolumn{1}{c}{46.10} \\
$\mathrm{TiO}_{2}$ & \multicolumn{1}{c}{2.14} & 2.88 \\
$\mathrm{Al}_{2} \mathrm{O}_{3}$ & $15.20(1.09)$ & $13.80(1.27)$ \\
$\mathrm{Fe}_{2} \mathrm{O}_{3}$ & $12.40(1.68)$ & $15.20(3.22)$ \\
$\mathrm{MnO}$ & $0.21(0.01)$ & $0.22(0.01)$ \\
$\mathrm{MgO}$ & $7.22(0.26)$ & $6.22(0.17)$ \\
$\mathrm{CaO}$ & $12.00(0.87)$ & $10.50(0.85)$ \\
$\mathrm{Na} 2 \mathrm{O}$ & $2.70(0.27)$ & $2.37(0.23)$ \\
$\mathrm{K}_{2} \mathrm{O}$ & $0.22(0.11)$ & $0.36(0.13)$ \\
$\mathrm{P}_{2} \mathrm{O}_{5}$ & $0.16(0.07)$ & $0.18(0.10)$ \\
$\mathrm{H}_{2} \mathrm{O}$ & 0.83 & 1.53 \\
$\mathrm{CO}_{2}$ & 0.00 & 0.04 \\
Total & 100.28 & 99.40
\end{tabular}

Trace elements (ppm)

\begin{tabular}{lrr}
$\mathrm{B}$ & $(12.4)$ & \multicolumn{1}{c}{$(63.4)$} \\
$\mathrm{Ba}$ & $30.0(15.0)$ & $22.0(<10)$ \\
$\mathrm{Co}$ & $98.2(13.0)$ & $94.5(9.6)$ \\
$\mathrm{Cr}$ & $137.0(<10)$ & $88.0(<10)$ \\
$\mathrm{Cu}$ & $75.4(26.8)$ & $63.4(24.3)$ \\
$\mathrm{Li}$ & $9.6(0.3)$ & $10.1(1.2)$ \\
$\mathrm{Ni}$ & $76.7(<5)$ & $69.2(<5)$ \\
$\mathrm{Sc}$ & $45.0(0.7)$ & $44.4(0.2)$ \\
$\mathrm{Sr}$ & $85.0(<10)$ & $65.0(<10)$ \\
$\mathrm{Ti}$ & $12800.0(1340)$ & $17300.0(2530)$ \\
$\mathrm{V}$ & $368.0(29.1)$ & $476.0(75.2)$ \\
$\mathrm{Y}$ & 35.7 & 40.0 \\
$\mathrm{Zn}$ & $124.0(27.6)$ & $159.0(44.0)$
\end{tabular}

Rare earth elements (ppm)

\begin{tabular}{lrr}
$\mathrm{La}$ & 3.80 & 2.89 \\
$\mathrm{Ce}$ & 12.10 & 12.10 \\
$\mathrm{Pr}$ & 2.16 & 2.00 \\
$\mathrm{Nd}$ & 11.10 & 11.40 \\
$\mathrm{Sm}$ & 4.31 & 4.18 \\
$\mathrm{Eu}$ & 1.44 & 1.55 \\
$\mathrm{Gd}$ & 5.23 & 5.72 \\
$\mathrm{Dy}$ & 5.91 & 6.68 \\
$\mathrm{Ho}$ & 1.29 & 1.45 \\
$\mathrm{Er}$ & 3.47 & 3.82 \\
$\mathrm{Yb}$ & 3.71 & 4.26 \\
$\mathrm{Lu}$ & 0.70 & 0.73 \\
\hline
\end{tabular}

Note: Total Fe expressed as $\mathrm{Fe}_{2} \mathrm{O}_{3}$. Values in parentheses are the $\mathrm{HCl}$-soluble portion of the sample. 